\title{
COMMERCIAL POTENTIAL OF NATURAL GAS STORAGE IN LINED ROCK CAVERNS (LRC)
}

Topical Report SZUS-0005 DE-AC26-97FT34348-01

by

Sofregaz US Inc.

200 WestLake Park Boulevard

Suite 1100

Houston, Texas 77079

UNITED STATES

and

LRC

S-205 09 Malmö, Sweden

Carl Gustafsväg 4

SWEDEN

prepared for

U.S. Department of Energy

Federal Energy Technology Center

P.O. Box 880

Morgantown, West Virginia 26507

UNITED STATES

November 1999 


\section{FOREWORD}

This report presents the results of a study performed by Sofregaz US, Houston, Texas, and LRC, a consortium composed of Gaz de France International S.A., Paris, France, and Sydkraft AB, Malmo, Sweden. In cooperation with LRC, NYSEG, Binghamton, New York, and ANR Storage Company of Detroit, Michigan, have reviewed the report. In addition to LRC, Acres American Inc., Buffalo, New York, and SPS Inc., Houston, Texas, contributed to the study effort in assessing state and federal permitting requirements and mapping pipelines, respectively. Dr. Joe L. Ratigan was Project Manager for Sofregaz US and Mr. Ola Hall was Project Manager for LRC. 


\section{EXECUTIVE SUMMARY}

The geologic conditions in many regions of the United States will not permit the development of economical high-deliverability gas storage in salt caverns. These regions include the entire Eastern Seaboard; several northern states, notably Minnesota and Wisconsin; many of the Rocky Mountain States; and most of the Pacific Northwest. In late 1997, the United States Department of Energy (USDOE) Federal Energy Technology Center engaged Sofregaz US to investigate the commercialization potential of natural gas storage in Lined Rock Caverns (LRC). Sofregaz US teamed with Gaz de France and Sydkraft, who had formed a consortium, called LRC, to perform the study for the USDOE.

Underground storage of natural gas is generally achieved in depleted oil and gas fields, aquifers, and solution-mined salt caverns. These storage technologies require specific geologic conditions. Unlined rock caverns have been used for decades to store hydrocarbons - mostly liquids such as crude oil, butane, and propane. The maximum operating pressure in unlined rock caverns is limited, since the host rock is never entirely impervious. The LRC technology allows a significant increase in the maximum operating pressure over the unlined storage cavern concept, since the gas in storage is completely contained with an impervious liner.

The LRC technology has been under development in Sweden by Sydkraft since 1987. The development process has included extensive technical studies, laboratory testing, field tests, and most recently includes a storage facility being constructed in southern Sweden (Skallen). The LRC development effort has shown that the concept is technically and economically viable. The Skallen storage facility will have a rock cover of 115 meters (375 feet), a storage volume of 40,000 cubic meters (250,000 petroleum barrels), and a maximum operating pressure of $20 \mathrm{MPa}$ (2,900 psi).

There is a potential for commercialization of the LRC technology in the United States. Two regions were studied in some detail - the Northeast and the Southeast. The investment cost for an LRC facility in the Northeast is approximately $\$ 182$ million and $\$ 343$ million for a 2.6billion cubic foot (bcf) working gas facility and a 5.2-bcf working gas storage facility, respectively. The relatively high investment cost is a strong function of the cost of labor in the Northeast. The labor union-related rules and requirements in the Northeast result in much higher underground construction costs than might result in Sweden, for example.

The LRC technology gas storage service is compared to other alternative technologies. The LRC technology gas storage service was found to be competitive with other alternative technologies for a variety of market scenarios. 


\section{TABLE OF CONTENTS}

1.0 INTRODUCTION AND SCOPE

2.0 DESCRIPTION OF THE LINED ROCK CAVERN TECHNOLOGY ....................... 2







2.2.2 Pressure-Absorbing Rock Mass..................................................................... 6

2.2.3 Pressure-Transferring Concrete Layer ......................................................... 6



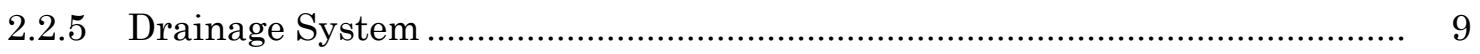

2.3 THE LRC TECHNOLOGY EIGHT-STEP DEVELOPMENT …................................ 10

2.4 SUMMARY OF THE GRÄNGESBERG PILOT PLANT RESULTS ......................... 11

2.4.1 Test Plan General Description .................................................................. 11

2.4.2 Test Plan Objectives............................................................................. 11

2.4.3 Test Program .......................................................................................... 13





3.0 MARKET DATA COLLECTION FOR CONVENTIONAL ALTERNATIVES ........... 15



3.2 GENERAL INVESTMENT COST PROFILE FOR UNITED STATES UNDERGROUND NATURAL GAS STORAGE..................................................................... 16

4.0 IDENTIFICATION AND SELECTION OF TWO GEOLOGIC CASES..................... 22



4.2 BEDROCK GEOLOGY OF NEW ENGLAND ........................................................ 22





4.3 BEDROCK GEOLOGY OF THE SOUTHEAST AREA ........................................... 28











5.1.2 General Rock Mechanics Aspects ........................................................... 36 


\section{TABLE OF CONTENTS (Continued)}

5.1.2.1 Expected General Behavior of the Rock Mass.................................... 36

5.1.2.2 Rock Mass Classification and Properties............................................. 38

5.1.2.3 Predicting the Deformation for the Grängesberg Pilot Plant ............ 40

5.1.2.4 Measured Deformations in Grängesberg Pilot Plant......................... 41

5.1.2.5 Comparison Between Predicted and Measured Behavior ................... 43

5.1.2.6 Behavior During Multiple Cycles........................................................ 44

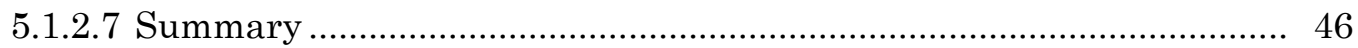



5.1.3.1 Theoretical Background ................................................................. 46

5.1.3.2 Study of Uplift in the Grängesberg Pilot Plant................................. 48

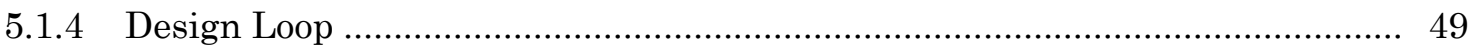

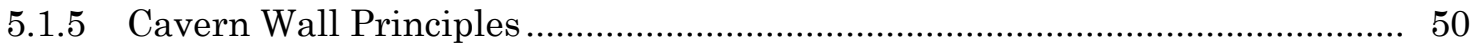

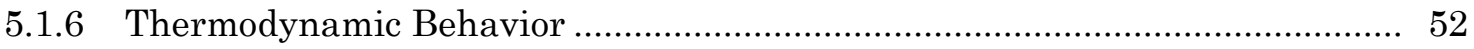

5.2 CONCEPTUAL DESIGN ............................................................................ 52



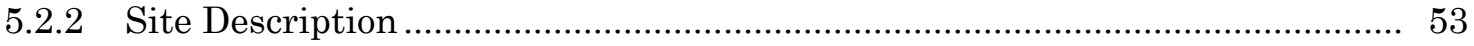

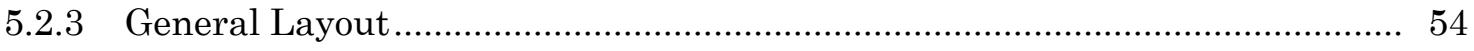

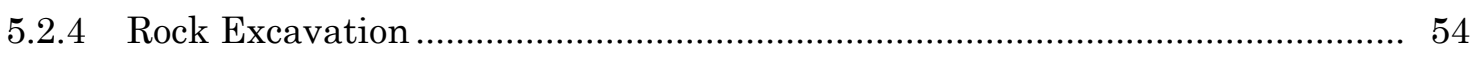

5.2.4.1 Excavation of the Tunnel Entrance .................................................. 55

5.2.4.2 Excavation of the Tunnels ............................................................... 55

5.2.4.3 Excavation of the Shafts .............................................................. 56

5.2.4.4 Installation Chambers Above the Caverns.......................................... 56

5.2.4.5 Excavation of the Rock Caverns ........................................................... 56

5.2.4.6 Excavation of the Barrier Positions ................................................... 57

5.2.4.7 Excavation of the Pump Pits........................................................... 58

5.2.4.8 Excavated Rock Treatment........................................................... 58

5.2.4.9 Treatment of Leakage Water .............................................................. 59

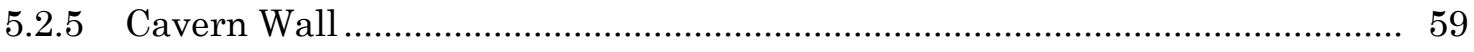

5.2.5.1 Concrete Wall ........................................................................... 59

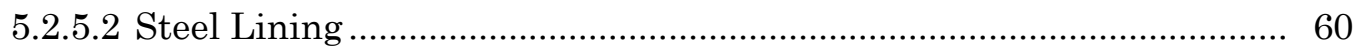

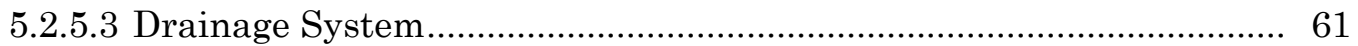

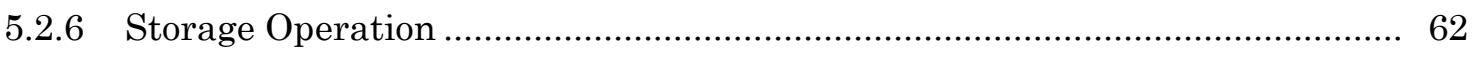

5.2.6.1 Injection With Flow Control ....................................................... 62 


\section{TABLE OF CONTENTS \\ (Continued)}

5.2.6.2 Injection With Compression.......................................................... 62

5.2.6.3 Withdrawal With Reduction ........................................................... 62

5.2.6.4 Withdrawal With Compression ...................................................... 64

5.2.6.5 Circulation Cooling/Heating........................................................... 64

5.2.7 Aboveground Facilities Layout and Main Equipment .................................... 64

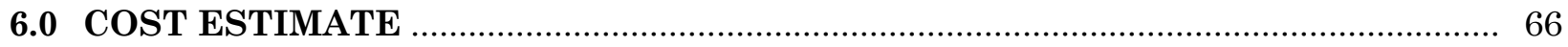

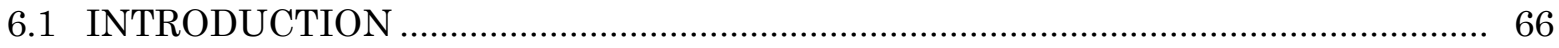

6.2 INVESTMENT COST FOR A FOUR-CAVERN FACILITY .................................. 67

6.2.1 Preconstruction Cost.................................................................................. 68

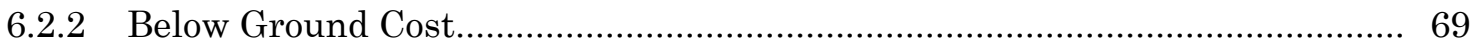

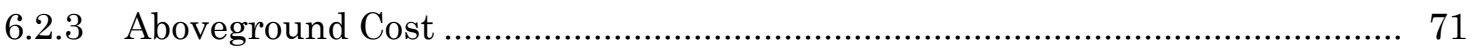

6.2.4 Total Investment Cost for a Four-Cavern Storage Facility ........................... 73

6.2.5 Operating Cost for a Four-Cavern Storage Facility .................................... 74

6.2.6 Total Investment Cost for an Eight-Cavern Storage Facility …..................... 74

6.2.7 Operating Cost for an Eight-Cavern Storage Facility .................................. 75

6.2.8 Comparison of Investment Cost in the United States to Investment Cost in Scandinavia ................................................................................................ 76

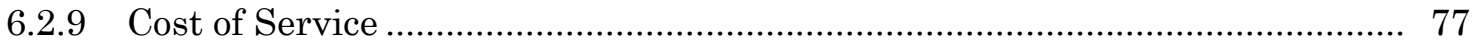

6.2.10 Cost Reduction Potential ............................................................................... 77

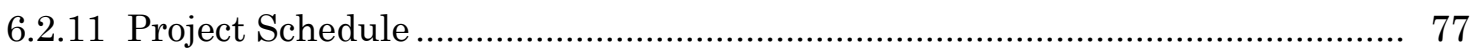

7.0 ECONOMIC COMPARISON OF LRC TO ALTERNATIVES .................................. 79

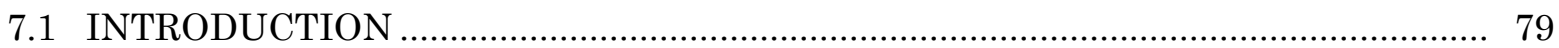

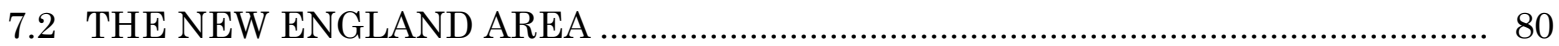

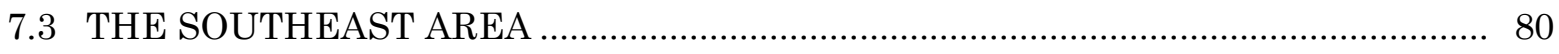

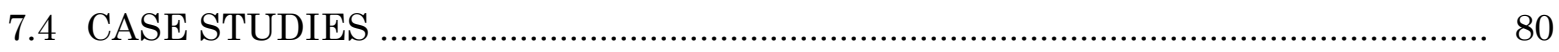

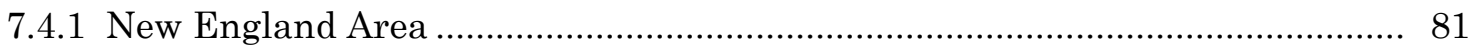



8.0 ENVIRONMENTAL IMPACT AND PERMITTING ISSUES .................................... 86

8.1 SUMMARY OF ENVIRONMENTAL IMPACT …............................................... 86

8.1.1 Environmental Effects During the Construction Period ................................. 86

8.1.2 Environmental Effects After the Construction Period...................................... 88

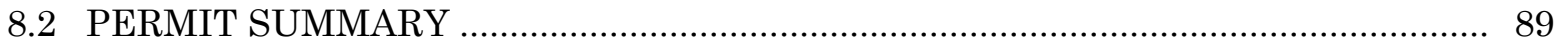




\section{TABLE OF CONTENTS \\ (Continued)}

9.0 REFERENCES

APPENDIX A. DESCRIPTION OF JOBFEM FINITE ELEMENT SOFTWARE ............ A-1

APPENDIX B. LRC GAS TEMPERATURE CALCULATIONS ...................................... B-1

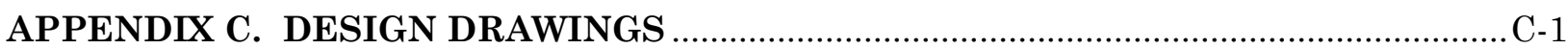

APPENDIX D. MANUAL FOR ECONOMIC MODEL …............................................ D-1

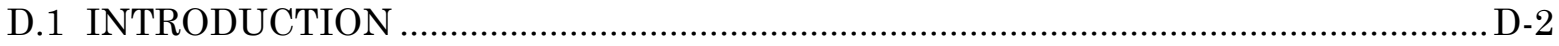

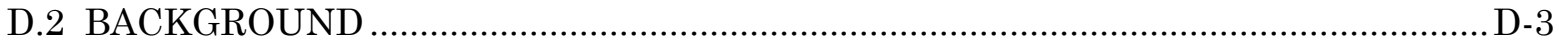

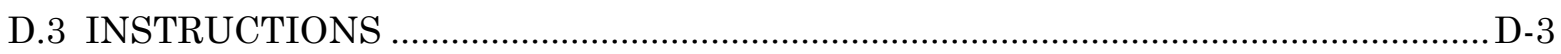

D.3.1 End User Input Data (Sheet 1) ................................................................. D-4

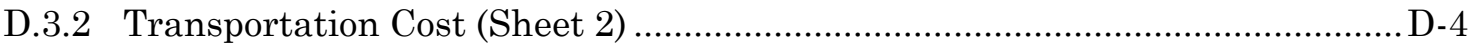

D.3.2.1 Transportation Cost to End User (1.) ….......................................... D-4

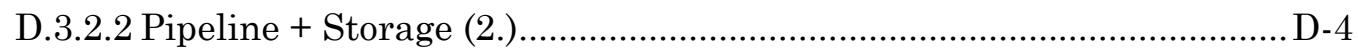

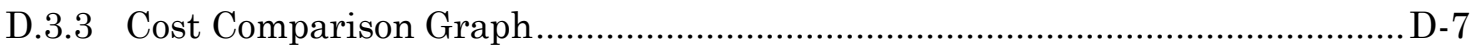

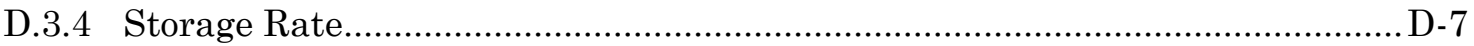

D.3.5 LRC Investment Cost.................................................................................... 


\section{LIST OF TABLES}

TABLE

PAGE

3-1 Summary of Median Size and Investment Cost per Unit Working Gas Volume ....... 20

3-2 Summary of Median Size and Cost per Unit Withdrawal Rate................................ 21

5-1 Methods Used in Grängesberg Pilot Plant to Estimate the Mechanical Properties

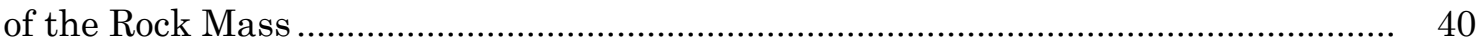

5-2 Parameters Used to Describe the Grängesberg Pilot Plant Site ............................. 40

6-1 Investment Cost for a Four-Cavern LRC Facility ................................................... 73

6-2 Annual Operating Cost for a Four-Cavern LRC Facility ........................................ 74

6-3 Investment Cost for an Eight-Cavern LRC Facility …............................................. 75

6-4 Annual Operating Cost for an Eight-Cavern LRC Facility …................................. 75

6-5 Investment Cost Comparison for LRC Storage Between the United States and

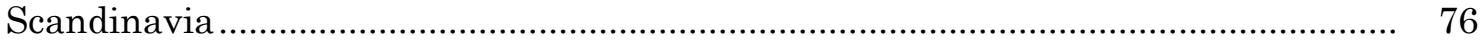

6-6 Cost Comparison for LRC Storage Between the United States and Scandinavia for Certain Below Ground Components................................................................ 76

6-7 Cost of Service per Deliverability for LRC Storage ............................................... 77

7-1 Cost Comparison for Various Storage Technologies ............................................. 81

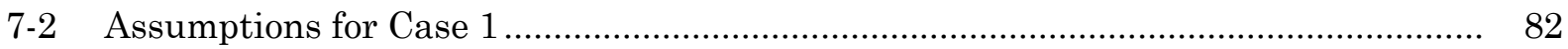

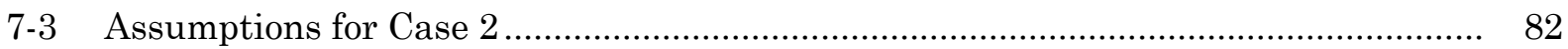

7-4 Comparison of Transportation Cost of 300 MDth Yearly at a Deliverability of 30

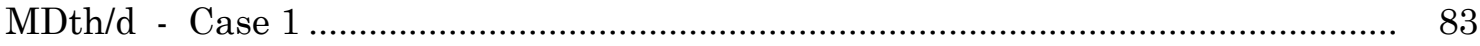

7-5 Comparison of Transportation Cost of 900 MDth Yearly at a Deliverability of 30 MDth/d - Case 2 ................................................................................................. 84

8-1 Federal and State Regulations That are or may be Applicable to the LRC Technology in Massachusetts ............................................................................... 90

8-2 Federal and State Regulations That are or may be Applicable to the LRC Technology in Georgia.... 


\section{LIST OF FIGURES}

2-1 Concept of Unlined Rock Cavern With a Water Curtain .......................................... 3

2-2 Schematic Illustration of the Lined Rock Cavern Concept ....................................... 5

2-3 Cavern Wall Design in the LRC ................................................................................... 7

2-4 Simple Model for Calculating the Uplift Effect …................................................ 8

2-5 Schematic Illustration of a Typical Test Room at Grängesberg, Sweden................. 12

3-1 Matrix Showing Characteristics for Different Types of Storage ............................. 17

3-2 Depleted Field Investment Cost per Unit Working Gas Volume ............................. 17

3-3 Depleted Field Investment Cost per Unit Withdrawal Rate..................................... 18

3-4 Aquifer Storage Investment Cost per Unit Working Gas Volume ........................... 18

3-5 Aquifer Storage Investment Cost per Unit Withdrawal Rate ................................. 19

3-6 Salt Cavern Investment Cost per Unit Working Gas Volume .................................. 19

3-7 Salt Cavern Investment Cost per Unit Withdrawal Rate .......................................... 20

4-1 Major Pipelines, Salt Basins, and Precambrian and Premesozoic Outcrops in the

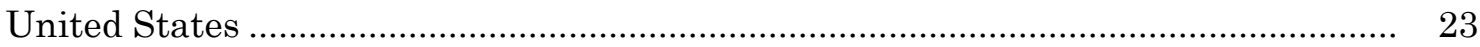

4-2 Index Map and Major Structural Features of Eastern Massachusetts..................... 24

4-3 Regional Location Map Showing Boundaries of the Greater Atlanta Regional Map

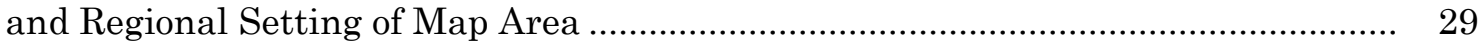

5-1 The Logic Chain of the Approach Adopted for the Grängesberg Pilot Plant Tests.... 37

5-2 Expected Principal Elasto-Plastic Behavior of the Rock Mass. Tensile Stresses in the Rock Surface Occur at Twice the Initial In Situ Stress, 2P (for an Isotropic Stress Field). Plastic Deformations Occur When the Compressive Strength of the Rock Mass, $\boldsymbol{\sigma}_{\mathrm{c}, \mathrm{m}}$, Is Exceeded

5-3 Illustration of the Different Deformation Zones Around a Pressurized LRC............ 38

5-4 Predicted Radial Deformations in Test Room 2 (for Horizontal Stress Conditions of 1.3 and 2.5 MPa), Grängesberg Pilot Plant. Expected Spread in Deformation Is Set at \pm 1 Millimeter

5-5 Predicted Distribution of Radial Deformation Along an 11.5-Meter-Long Extensometer

5-6 Total Radial Deformations Measured in all Three Test Rooms (Grängesberg Pilot Plant)

5-7 Measured Distribution of Radial Deformation Along an 11.5-Meter-Long Extensometer 


\section{LIST OF FIGURES \\ (Continued)}

5-8 Deformations in all Horizontal Extensometers in the Three Test Caverns Along With the Predicted Deformations According to JOBFEM (Two Thick Lines for Two Different Horizontal Stress Conditions). The Expected Spread Was Set at \pm 1 Millimeter

5-9 Measured Change in Diameter (K7, K8) and Height (K9) of Test Room 2 During 50 Cyclic Pressure Loads Between 15 and $30 \mathrm{MPa}$.

5-10 Additional Rock Deformation Registered in Test Room 2 During 100 Pressure Cycles Between 1 and 16.5 MPa.

5-11 Uplift of Cylindrical Anchor Plates.

5-12 Resistance Against Uplift With a Cone-Shaped Rock Overburden

5-13 The Resistance of the Rock Mass Against Uplift Calculated With Three Different Methods for the Grängesberg Pilot Plant (Cavern Diameter 4.4 Meters and Actual Rock Cover 50 Meters)

5-14 Design Loop for Technical and Economical Optimization of a Lined Rock Cavern for Storage of Gas

5-15 Method for Judging the Potential of a Site for LRC Storage ................................... 50

5-16 Horizontal Projection of Storage Showing the Sandwich Wall................................ 51

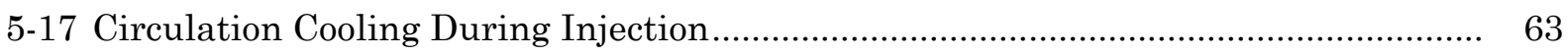

5-18 Circulation Heating During Withdrawal.............................................................. 63

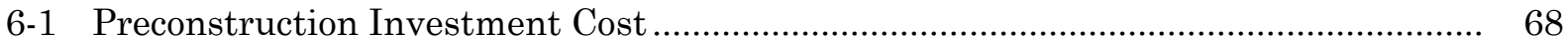

6-2 Uncertainties for Preconstruction Cost .............................................................. 69

6-3 Below Ground Investment Cost........................................................................ 70

6-4 Largest Uncertainties for Below Ground Cost ..................................................... 71

6-5 Aboveground Investment Cost........................................................................ 72

6-6 Largest Uncertainties for Aboveground Cost ......................................................... 73

6-7 Time Schedule for a Four-Cavern LRC Storage..................................................... 78

B-1 Pressure and Temperature Variation in the Cavern................................................ B-4

D-1 Alternatives for Gas Transportation.................................................................. D-2

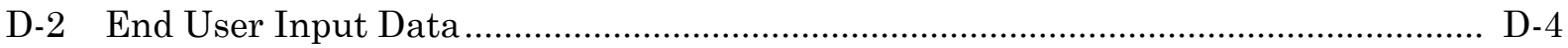

D-3 Transportation Cost to End User …….............................................................. D-5

D-4 Transportation Cost to Storage …................................................................. D-5

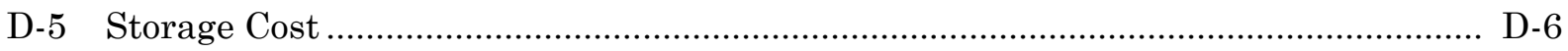




\section{LIST OF FIGURES}

(Continued)

FIGURE

PAGE

D-6 Transportation Cost to End User ..................................................................... D-7

D-7 Cost Comparison Graph .................................................................................... D-7

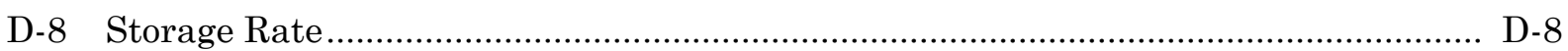

D-9 LRC Investment Cost ................................................................................. D-8 


\subsection{INTRODUCTION AND SCOPE}

In late 1997, Sofregaz US was engaged by the Federal Energy Technology Center (FETC) to investigate the commercialization potential of natural gas storage in Lined Rock Caverns (LRC). Sofregaz US teamed with Gaz de France and Sydkraft to perform the study for the Department of Energy.

The geologic conditions in many regions of the United States will not permit the development of economical high-deliverability gas storage in salt caverns. These regions include the entire Eastern Seaboard; several northern states, notably Minnesota and Wisconsin; many of the Rocky Mountain states; and most of the Pacific Northwest. This study addresses the development of a design and associated cost estimate for lined rock caverns for these regions of the United States. The study addresses the development of LRC at two locations: one along the Southeastern Coast and the other in the Northeast.

In Chapter 2.0, the state-of-the-art in LRC technology is described. Chapter 3.0 provides a summary of the market data for conventional storage alternatives in the area in which the LRC technology is being proposed. The two geologic sites are described in Chapter 4.0, and the conceptual LRC design is presented in Chapter 5.0. Chapters 6.0 and 7.0 present the cost estimate and a comparison to conventional alternatives for storage. Chapter 8.0 provides a

very brief review of the environmental issues associated with the LRC and the permitting issues that need to be addressed with such a development. The report concludes with cited references and several appendices with detailed information. 


\subsection{DESCRIPTION OF THE LINED ROCK CAVERN TECHNOLOGY}

\subsection{BACKGROUND}

Underground storage of natural gas is conventionally achieved in depleted oil and gas fields, aquifers, and solution-mined salt caverns. It requires specific geological conditions not available everywhere. Alternatives to conventional underground storage are LNG and propane-air peak-shaving facilities. However, these alternatives are costly. The LRC technology is a new alternative to conventional underground storage of natural gas.

Unlined rock caverns have been used for decades to store a wide range of low vapor pressure products, mostly liquids such as crude oil, butane, and propane. Since the host rock is never completely impervious, product confinement within the cavern is sometimes achieved through the water curtain technique. The idea is to have water continuously flowing toward the cavern from outside so that the stored product can never escape and migrate out of the cavern. The cavern must be sited deep enough to make sure that the water hydraulic pressure in the fractures of the rock around the cavern is always higher than the vapor pressure of the product stored in the cavern. The water pressure is maintained by injecting water into the rock through horizontal water holes above the cavern ("the water curtain") in order to maintain a stable groundwater table level. Figure 2-1 illustrates the storage concept of an unlined rock cavern with a water curtain. The same concept of unlined rock with a water curtain has been envisaged for air and even natural gas, but it becomes uneconomical as soon as large storage capacity is required. Indeed, unlined rock caverns must be sited very deep to enable a sufficiently high storage pressure. With the new LRC concept, this constraint can be alleviated since gas containment within the cavern is ensured by the lining.

The LRC technology has been under development by Sydkraft in Sweden since 1987. There are no suitable geological conditions for conventional underground gas storage in Scandinavia. The geology of those countries (Finland, Sweden, and Norway), with the exception of Denmark, is largely dominated by crystalline bedrock. Since the penetration of natural gas into the energy market is growing, it has become critical for Scandinavian gas companies to find a way to store natural gas underground. Sydkraft, the largest private energy group in Sweden in the field of electricity, natural gas, LPG and heating systems, has taken the lead for development of the new technology adapted to the Scandinavian geology; the LRC technology. The LRC development program began in 1987 with Sydkraft in a leading role and with the participation of several Scandinavian entities; among them: Neste, Skanska, Statoil, Swedgas, and Vattenfall. Sydkraft entered into a partnership agreement with Gaz de France in 1995 to jointly evaluate the feasibility for an LRC demonstration plant in Sweden. The feasibility study involving the construction of an LRC demonstration plant is now complete and construction has started. 
RSI-835-99-079



Figure 2-1. Concept of Unlined Rock Cavern With a Water Curtain. 


\subsection{THE LRC STORAGE CONCEPT}

\subsubsection{Overall Description}

Figure 2-2 illustrates the LRC storage concept. The underground facility consists of one or more storage caverns, a vertical shaft, and a system of tunnels connecting the caverns with the ground surface. The storage caverns are excavated in rock as vertical cylinders.

Caverns are planned to be located at a depth of about 100-200 meters below ground (300600 feet). The maximum storage pressure will be in the range of 15-30 $\mathrm{MPa}$ (2,200-4,350 psi), with typical cavern dimensions of 35-40 meters (100-120 feet) in diameter, 60-100 meters (200-340 feet) in height, and 12-30 million $\mathrm{Nm}^{3}$ (400-1,100 million cubic feet (MMcf)) of natural gas storage (working volume) capacity.

The aboveground facility includes a compressor station, heating equipment, piping, valves, metering, and control system. A dehydration unit will only be needed on a temporary basis upon initiating gas storage service. Injection into the cavern is done directly from the pipeline by flow control when the storage pressure is lower than the pipeline pressure. When the cavern pressure is higher than the pipeline pressure, compression is used to boost gas pressure. Before being injected into the cavern, the gas is cooled (after compression) by an air or water cooler. During gas injection, when the pressure is higher in the cavern than in the pipeline, some gas will be withdrawn from the cavern by a separate compressor, circulated through a cooler, and injected back into the cavern. This will increase the working gas volume in the cavern. In order to further enhance the working gas capacity, the recirculated gas can be cooled to a lower temperature by means of a refrigeration unit.

Withdrawal is normally done by free flow from the cavern to the transmission line. Compression is used when the storage pressure falls below the pipeline pressure. To avoid too low of a gas temperature in the cavern at the end of withdrawal, gas can be heated in a heat exchanger and recirculated into the cavern. The gas also needs to be heated before pressure

reduction in the withdrawal mode when the difference in pressure between the cavern and the pipeline is high.

The LRC design is based on the combination of a few key components:

- The surrounding rock mass to absorb the forces

- A concrete layer serving as a base for the lining and as a load transfer media between the gas pressure forces and the rock

- A thin lining enclosing the gas in the cavern. 


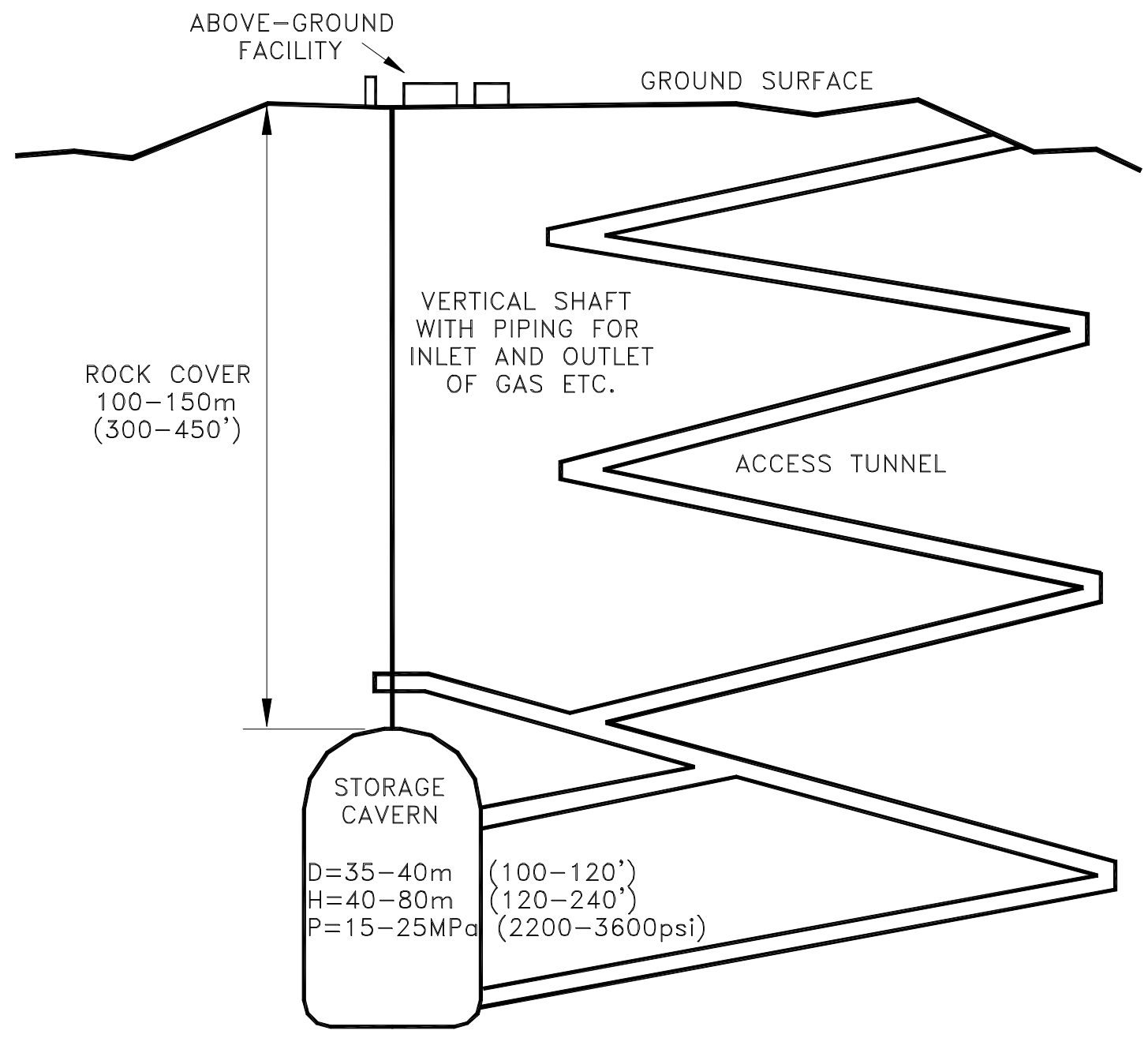

Figure 2-2. Schematic Illustration of the Lined Rock Cavern Concept. 
A fourth component, the drainage system between the cavern wall and liner, has been added to handle groundwater influx. Figure 2-3 illustrates the design of the cavern wall, liner, and drainage system.

\subsubsection{Pressure-Absorbing Rock Mass}

The rock mass surrounding the cavern is the pressure-absorbing medium, and thus, the pressure vessel. Typically, for most common rocks contemplated so far for LRC, the surrounding rock mass starts to deform both elastically and plastically at pressures over about $4 \mathrm{MPa}$ (600 psi). The magnitude of these early deformations is critical since it contributes to the ultimate strain of the lining.

A certain thickness of rock coverage is required to prevent the rock mass from uplifting when gas is pressurized in the cavern. Figure 2-4 illustrates a simple model for calculating the uplift effect and implies how much rock coverage must be taken for a given cavern diameter and maximum operating pressure. This model includes rock characteristics $(\alpha)$, in situ depth conditions $\left(\sigma_{\eta}\right)$, cavern depth $(z)$ and geometry $(D)$, and operating parameters $(p)$.

\subsubsection{Pressure-Transferring Concrete Layer}

A concrete layer is cast between the lining and the rock. The purpose of this concrete layer is twofold:

1. Transfer the load generated by the gas pressure in the cavern to the surrounding rock mass.

2. Provide a smooth base for the lining.

The concrete layer also has a role to minimize the strain in the lining. The large cracks that can be generated by the lining deformation result in a number of smaller cracks in the concrete; thus, producing a strain in the lining.

Concrete reinforcement may vary, depending on the geological conditions and the type of lining. The need for concrete reinforcement will decrease with a higher rock mass strength. However, if the frequency of fractures is too low (e.g., only of few larger fractures), increased reinforcement has to be incorporated. The amount of reinforcement is also related to the liner. With a thin liner, the allowance for the maximum width of cracks is lower than for a thick liner. The crack width is controlled by the amount of the reinforcement.

\subsubsection{Gas-Tight Lining}

The lining material must be gas-tight and chemically resistant to gas and to the possible condensates and impurities that it may contain, as well as to the outside environment. From a structural standpoint, the lining is not supposed to carry primary loads as it is supported by the 


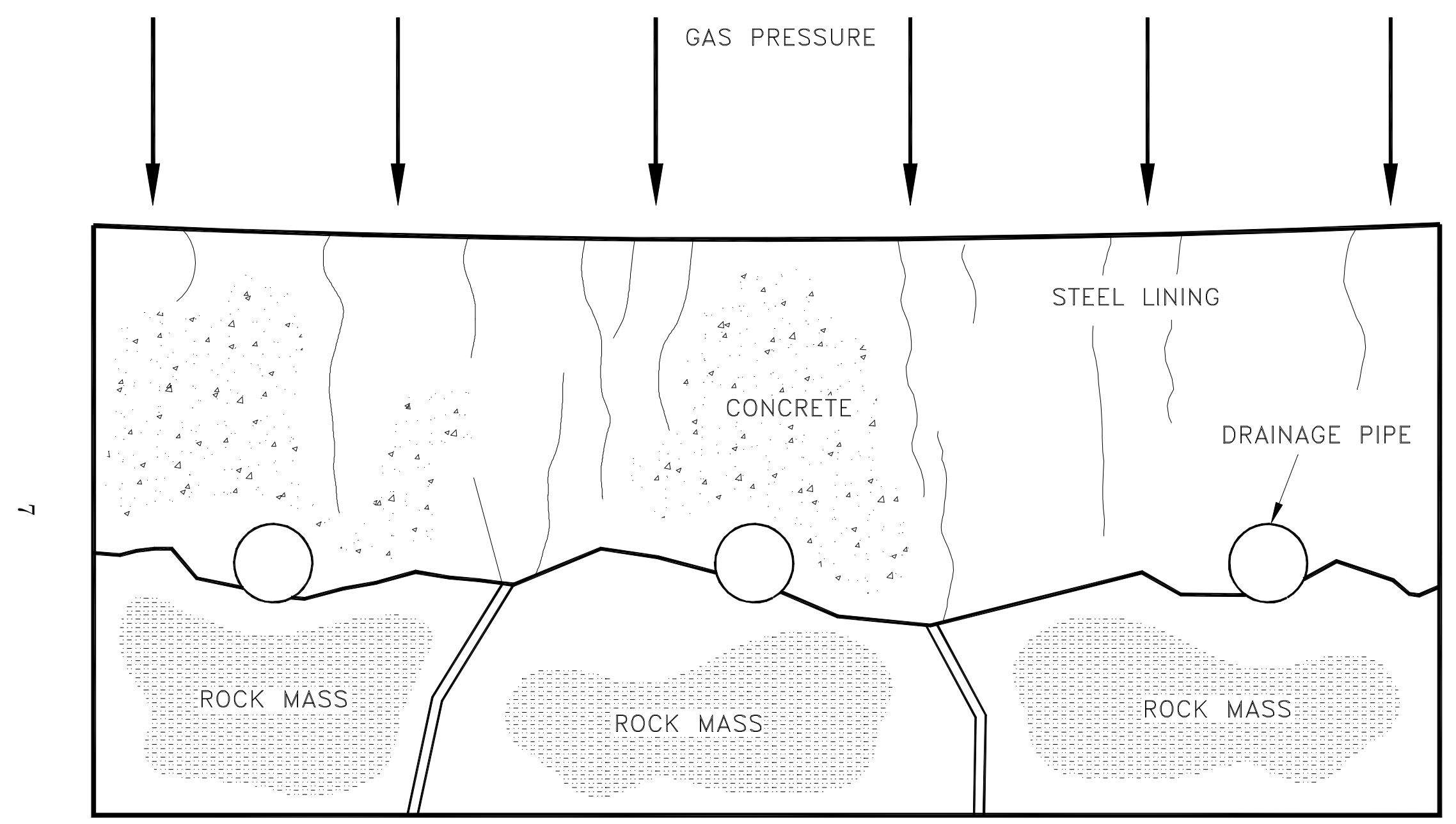

Figure 2-3. Cavern Wall Design in the LRC. 
RSI-835-99-082

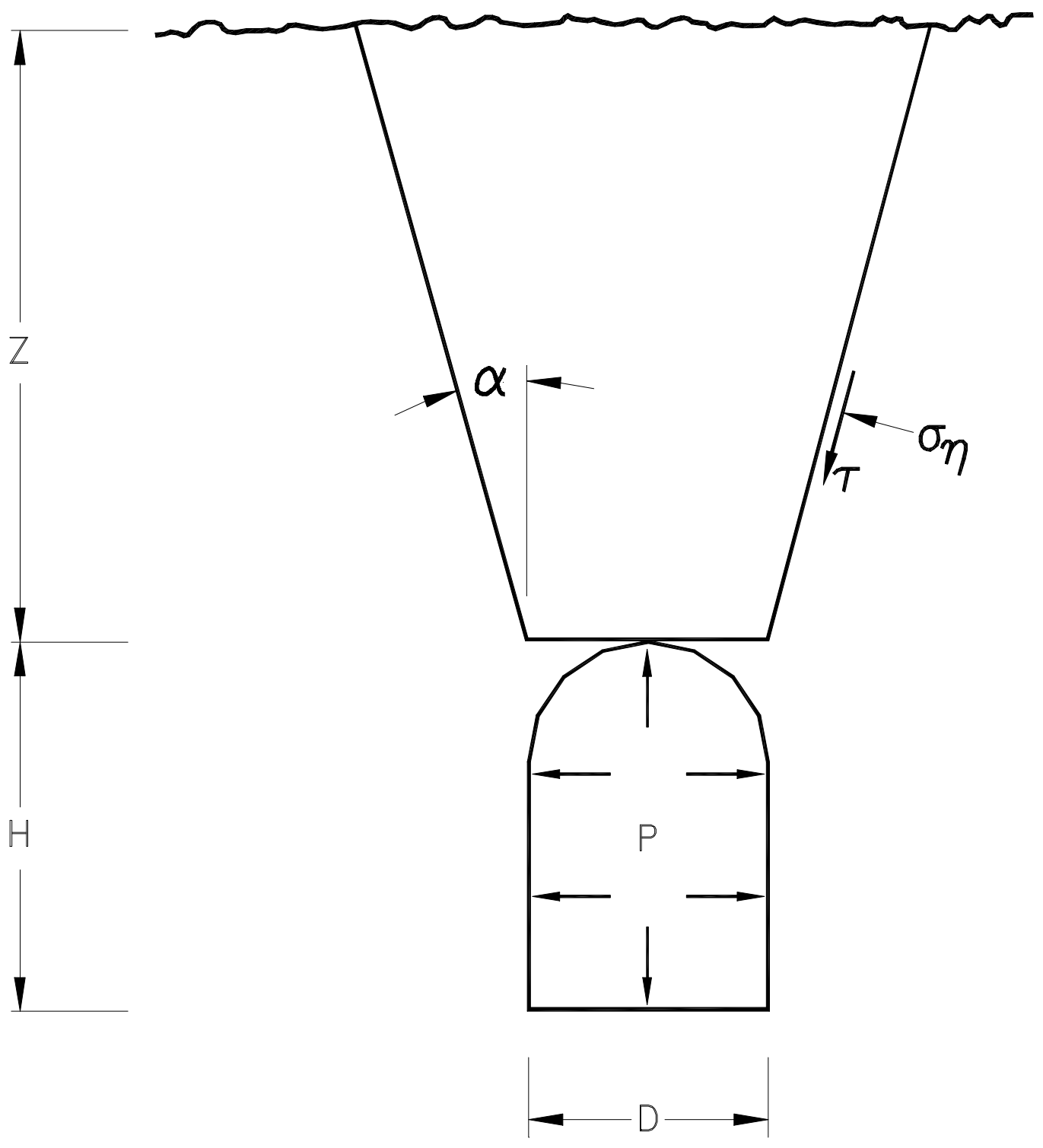

Figure 2-4. Simple Model for Calculating the Uplift Effect. 
concrete layer, which in turn, is supported by the surrounding rock mass. The lining shall, however, be able to resist the stress and strain caused by the general elastic and plastic deformation of the cavern wall. In addition, with increasing gas pressure, fractures and cracks will open up in the rock mass. These will initiate smaller cracks in the concrete layer. The liner must then have the capacity to withstand the strain resulting from the spanning of the largest of those cracks. Experiments have shown that many lining materials can support crack spans of up to 2 millimeters in the concrete layer without any problem.

The maximum operating pressure permissible for the storage depends on the lining characteristics and the geological conditions. It must be set at a value such that the induced deformation in the rock mass and the concrete layer does not result in a strain in the lining in excess of its capacity for deformation.

Another issue to consider when designing the lining of the cavern wall is its durability in terms of resistance to repeated mechanical deformation and to chemical aggressiveness. Numerous materials have been tested by the Geotechnical Engineering Department of the Chalmers Technological University of Gothenburg, Sweden. Two categories of material were tested:

- Plastic materials

- Steel.

A number of plastic lining materials have been tested in the laboratory, including polyethylene (PE), poly-vinyl chloride (PVC), and butyl. Low-density polyethylene (LDPE) and PVC show better deformation capabilities than high-density polyethylene (HDPE). Those materials are flexible enough to be used on irregular surfaces. However, it is known that some of the condensates contained in natural gas may soften plastic materials, and long-term imperviousness cannot be guaranteed. Of the common plastic materials, only certain polypropylenes have been classified to be chemically stable and impervious in the long term.

In addition to plastic materials, both carbon steel and thin stainless steel linings have been studied. The carbon steel concept can be described as a conventional storage tank placed in a rock cavern with the space between the tank and the rock filled in with concrete. Stainless steel is more resistant to corrosion than carbon steel. The stainless steel selected for the tests and for further consideration is an austenitic steel, which is ductile and has the ability to bridge over cracks.

\subsubsection{Drainage System}

Since the lined rock caverns are planned to be placed at 100-200 meters (300-600 feet) in depth, the hydrostatic pressure outside of the cavern due to the column of groundwater can be 1-2 $\mathrm{MPa}$ (150-300 psi). If the operating gas pressure within the cavern is expected to be lower 
than the hydrostatic pressure outside the cavern, or if the cavern is depressurized to the atmospheric pressure for inspection and/or maintenance, the lining could be exposed to a load from the outside. A drainage system installed outside the cavern, within its wall, could have the function of reducing that hydrostatic pressure by draining the flowing groundwater.

\subsection{THE LRC TECHNOLOGY EIGHT-STEP DEVELOPMENT}

The LRC technology has been developed step-by-step over a period of more than 10 years, since the initial step in 1987. Seven steps have already been completed, and the eighth and final step, the construction of the demonstration plant, was started in 1998 by the partners in the project: Sydkraft and Gaz de France.

- Step 1 - Conceptual Studies [Sydgas et al., 1987a, 1987b, 1989; Sydgas, 1990a, 1990b, 1992; Sydkraft and Vattenfall, 1992]

The first step consisted of basic conceptual studies and was conducted from 1987 through 1992 by a combination of Scandinavian companies, including Sydkraft, Sydgas, Swedgas, and Vattenfall. These studies principally addressed the issue of the cavern lining and its tightness to gas.

\section{- Step 2 - Experimental Tests [Stille et al., 1994]}

During the second step, from 1990 to 1994, the two concepts of gas storage in rock caverns with a water seal and storage at low temperature (chilled storage) were studied through a series of tests performed in the Röda Sten experimental rock cavern.

\section{- Step 3 - Grängesberg Pilot Plant [Stille et al., 1994]}

A pilot plant was constructed in 1988-1989 at Grängesberg and was used for testing from 1989 through 1993. The purpose was to experiment with different linings, to test the cavern under pressure and evaluate the effect of increasing pressure, to test the benefit of reduced storage temperature, to further investigate the feasibility of stainless steel lining, to better understand the fracture mechanism in the surrounding rock, and to test the consequence of leakage in the liner at high pressure. The results of this pilot plant at Grängesberg are presented in Section 2.4.

\section{- Step 4 - Test Plant Results Interpretation}

The fourth step consisted of compiling and analyzing the test plant results and was completed in 1995.

- Step 5 - Technical Studies [Sydkraft and Skanska, 1995a; 1995b; 1995c; 1995d; 1995e; 1995f; 1995g; 1995h; 1995i; 1995j]

The fifth step, implemented in 1994-1995, included various technical studies, such as definition of operating conditions, siting criteria, risk analysis, modeling of sandwich wall 
construction and drainage system, rock mechanics studies, quality assurance, creation of the circulation system, and development of an aboveground plant simplified design.

\section{- Step 6 - Engineering Studies}

During the sixth step, from 1994-1996, engineering work was accomplished, including optimization of costs, design of sandwich wall and drainage system, gas leakage detection, study of high withdrawal and injection rates, quality control, and market analysis.

\section{- Step 7 - Risk Assessment and Preliminary Design [Sydkraft and Gaz de France, 1996a; 1996b; 1997]}

The seventh step, started in 1996, was completed in 1997. It addressed mostly the risk assessment and the preliminary design of the demonstration plant.

\section{- Step 8 - Demonstration Project}

Implementation of the eighth step was approved by the partners in October 1997. This step consists of building and testing a demonstration plant of industrial scale. The construction work started in the fall of 1998, and commissioning is scheduled for the beginning of 2001. The storage will be located at Skallen near Halmstad in southern Sweden. The geometric volume will be 40,000 $\mathrm{m}^{3}$ (1.4 MMcf or 250,000 barrels (bbls)), which is about one-half the size of a commercial cavern.

\subsection{SUMMARY OF THE GRÄNGESBERG PILOT PLANT RESULTS}

\subsubsection{Test Plan General Description}

The LRC concept was successfully tested in the pilot plant of Grängesberg between 1988 1992 (e.g., Stille et al. [1994]). This was a critical step before deciding on building a full-scale demonstration plant. Grängesberg is situated in central Sweden, 250 kilometers west of Stockholm. The predominant type of rock in the area is medium-grained granite. The plant construction was started in 1988 and was completed in 1989. Three test rooms were excavated as vertical cylinders. The schematic of a typical test room is shown in Figure 2-5. Each test room is 4.4 meters in diameter (14 feet) and 9 meters high (28 feet). The rock overburden above the test rooms is 50 meters (179 feet) thick. The rooms are lined on the inside with concrete and steel.

\subsubsection{Test Plan Objectives}

The main objectives of the test plan were as follows:

- Test the entire system under realistic load conditions.

- Test and evaluate different lining materials. 


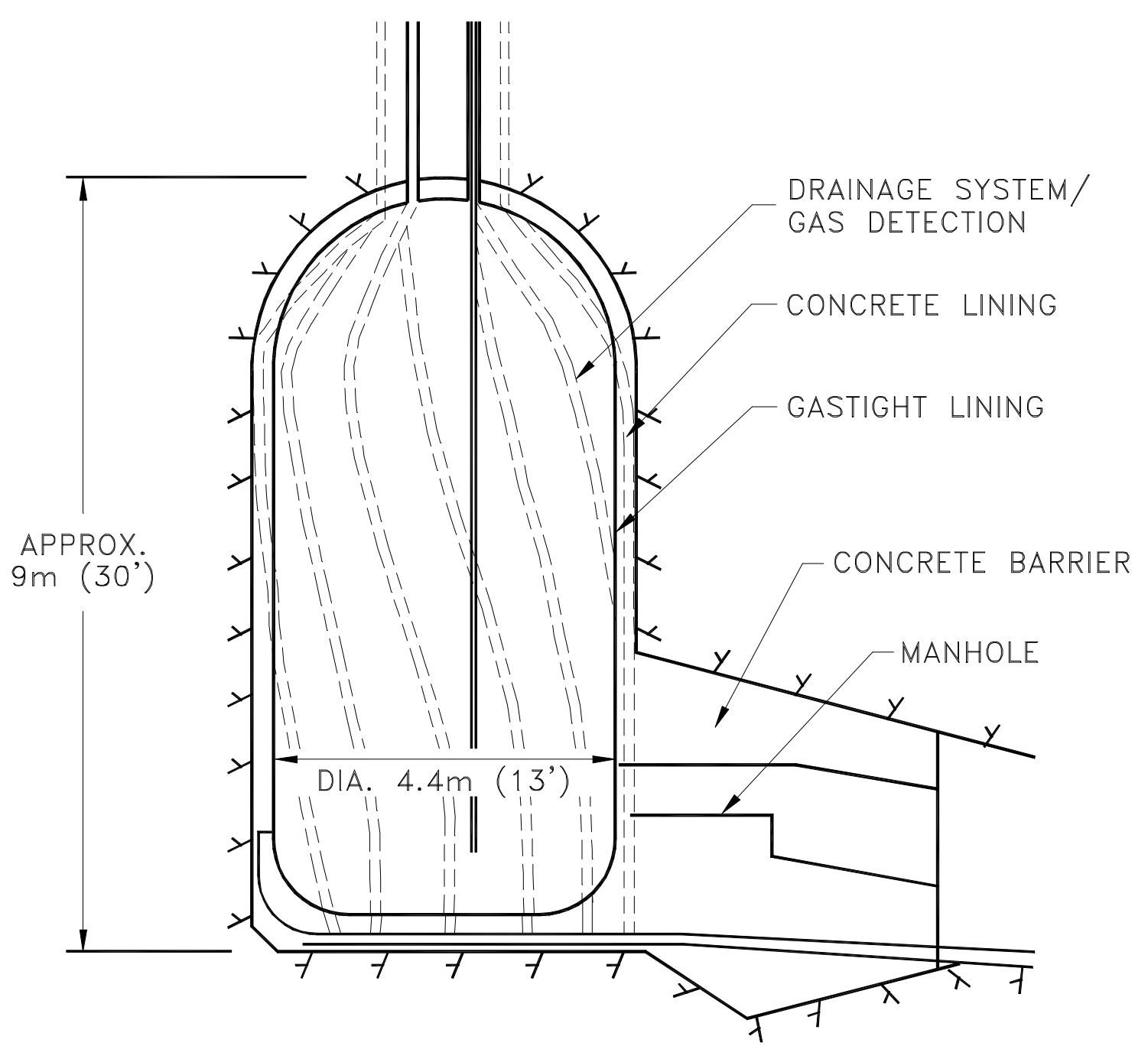

Figure 2-5. Schematic Illustration of a Typical Test Room at Grängesberg, Sweden. 
- Analyze bedrock behavior under different pressure and temperature conditions.

- Test the drainage system.

- Demonstrate the viability of the LRC concept on a small scale.

In order to achieve those objectives, each of the test rooms was heavily equipped with instrumentation for several different independent measurement systems, including:

- Extensometers measuring movements in the rock radially and vertically

- Mini-extensometers measuring movement at the interface between rock and concrete

- Convergence meters measuring the remaining deformation after each test

- Measurement to determine the remaining deformation in the lining

- Convergence measurement to determine deformation in the concrete barriers and in the adjacent tunnels

- Continuous monitoring of pressure and temperature in the test rooms and continuous temperature monitoring in the concrete layer and the rock.

\subsubsection{Test Program}

Tests were carried out in four phases during 1989-1993. Room \#1 was lined with thin stainless steel. Room \#2 was lined with carbon steel. Room \#3 was initially lined with polypropylene which ruptured in an early stage of the test, and the room was later relined with thin stainless steel.

Limited pressure tests have been carried out in Room \#1 with a maximum pressure of $14 \mathrm{MPa}$ (2,000 psi). In Room \#2, comprehensive pressure tests have been carried out, including more than 200 load cycles up to a maximum pressure of $52 \mathrm{MPa}(7,500 \mathrm{psi})$. Room \#3 has been subjected to a great number of load cycles up to a maximum pressure of $26 \mathrm{MPa}(3,800 \mathrm{psi})$.

\subsubsection{Test Results}

The deformations measured in the surrounding rock, the concrete layer, and the lining were relatively small considering the high-pressure levels experienced. The rock mass accounted for 50 percent of the total radial deformation in the lining. The remaining 50 percent was absorbed by the concrete layer and the transition zone between the concrete and the rock. The concrete layer, when inspected after dismantling the steel liner, was relatively intact. Cracks and crack zones were formed, but no large pieces of loose concrete nor crushed zones were found. Strains in the steel higher than the yield point were observed. However, the metallurgic analysis performed on samples showed that the structure and properties of the steel had not been modified by the high-pressure loading. 
The most important result from the Grängesberg tests was that the rock mass proved its function as a pressure vessel at pressure levels comparable to those intended for a commercial storage plant. The maximum operating pressure of the commercial plant has to be selected according to the surrounding rock mass mechanical properties so that the capacity of deformation of the liner is not exceeded.

\subsection{SUMMARY}

The LRC technology has been developed step-by-step over a period of 10 years and has been proven technically feasible through the various tests performed at the Grängesberg Pilot Plant. The LRC storage concept has the following advantages compared to the conventional underground storage of natural gas:

- The size of the LRC storage can be customized to specific needs and can be then expanded by phases, if needed.

- Provided that adequate geology is present, LRC storage can be located at gas consumption centers.

- Gas is never in contact with groundwater, and dehydration during the withdrawal mode is unnecessary.

- LRC storage is structurally stable and the base gas requirement is minimal.

- LRC storage possesses the same ability as a salt cavern to deliver high withdrawal rates and to be cycled several times in a year. 


\subsection{MARKET DATA COLLECTION FOR CONVENTIONAL ALTERNATIVES}

\subsection{STORAGE DEMANDS}

The storage alternatives that LRC has to compete with are depleted fields, aquifers, salt caverns, and LNG. When comparing different alternatives, several aspects have to be considered, depending on the end customers' need. The customer profile and transportation profile will create the type of service needed from the storage; thus, determining which cost aspect is the most important for the storage to possess: low cost per working gas, low cost per deliverability, or low cost for swing service and multiple cycles.

The customer profile is determined by the type of customer and the type of service needed from storage. The main customers for an underground storage service are:

- Local Distribution Companies (LDC)

- Power generation companies

- Transportation companies

- Marketers.

The LDCs supply residential and commercial customers in their territory. They have a monopoly for that service, but there is an ongoing process of dissolving this monopoly. The LDCs mainly have two types of variations in demand to consider:

1. Seasonal variations between winter and summer

2. Peak variations due to extreme weather conditions.

The power generation companies are anticipated to cause the major growth in gas consumption along the Atlantic coast. If a power plant is not a base-load plant, the plant will need to face several variations in their load:

- Seasonal variation with winter and summer peaks (air conditioning)

- Weekly, daily, and hourly variations due to lower power demand during weekends and peak demands during mornings and evenings.

The short-term variations require close proximity between the power plant and the storage to be able to deliver the high amounts at a very short notice. If the distance between the storage and the power plant is too long, a short-term peak demand can cause a pressure drop in the supplying pipeline; thus, reducing the transportation capacity in the pipeline that supplies the power plant as well as other customers with natural gas. 
The transportation companies need to balance swing in pipeline demand in order to maximize annual transmission capacity. They also provide "no-notice" and other swing services, creating variations that can be balanced with storage.

Marketers are used more and more by LDCs and power generation companies to coordinate the supply and transportation arrangements from the gas supply areas to the market. In that role, they have the same basic needs for storage as the LDC or power generation company. Often, a marketer tries to optimize the supply portfolio by utilizing short-term contracts and futures; thus, taking opportunities from the prevailing market. These activities also result in a demand for short-term storage (i.e., parking and loaning).

Based on the background given above, storage cost is interesting to study from different perspectives, depending on the customer demand. The different types of storage have different profiles, which makes them more or less attractive, depending on the anticipated service. Cost parameters of interest to study when comparing different types of storage are:

- Investment cost/cost of service

- per working gas

- per deliverability

- per swing

- for multiple cycles

- Operational cost.

Figure 3-1 shows typical performance for different types of storage. This figure illustrates the base for the storage cost profile for the different types of storage user. From the matrix, one can see that salt cavern and LRC are interesting for relatively small volumes and have good injection and withdrawal performance, which means they are suitable for peak service, swing service, parking and loaning, and balancing in pipelines and power generation.

\subsection{GENERAL INVESTMENT COST PROFILE FOR UNITED STATES UNDER- GROUND NATURAL GAS STORAGE}

In order to provide a picture of average levels of United States' storage investment costs, the capital investment cost data for projects available from the Energy and Environmental Inc. [1994] and Thompson [1997] are presented in Figures 3-2 through 3-7. The different storage types have been divided into three major groups based on their working gas capacity. In order to reflect the full range of the costs, all projects are represented by the light-colored bar. 


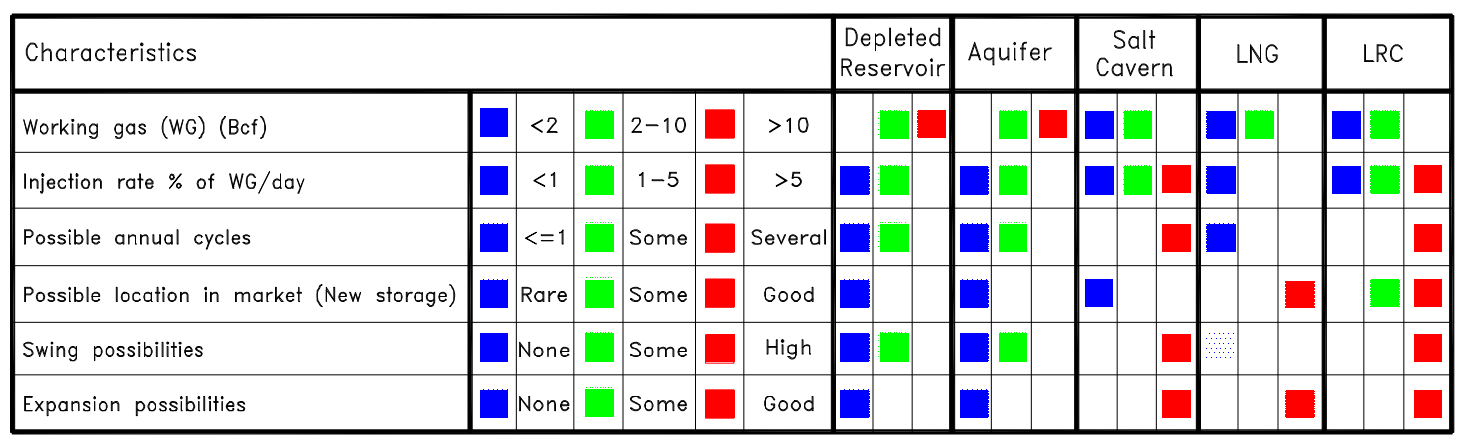

Figure 3-1. Matrix Showing Characteristics for Different Types of Storage.

RSI-835-99-085

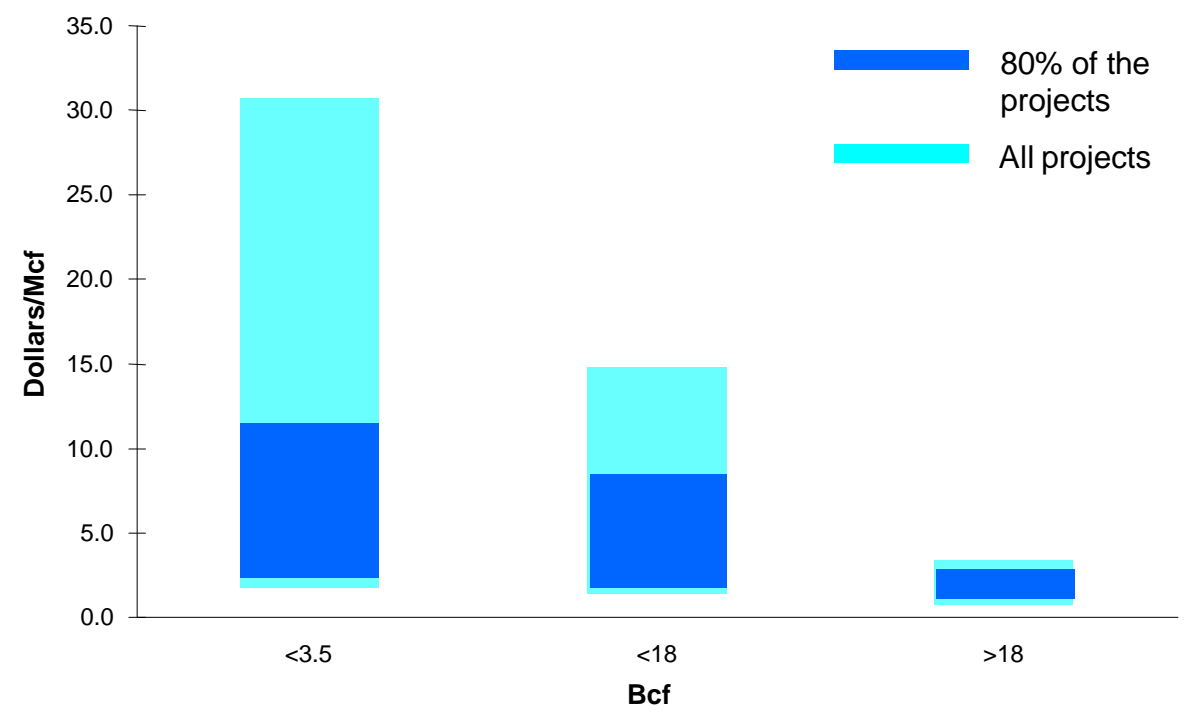

No. of projects $=41$

Median costs for capacity for sizes:

$<3.5 \mathrm{Bcf}=\$ 5 / \mathrm{Mcf}$

$<18 \mathrm{Bcf}=\$ 3 / \mathrm{Mcf}$

$>18 \mathrm{Bcf}=\$ 2 / \mathrm{Mcf}$

Figure 3-2. Depleted Field Investment Cost per Unit Working Gas Volume. 


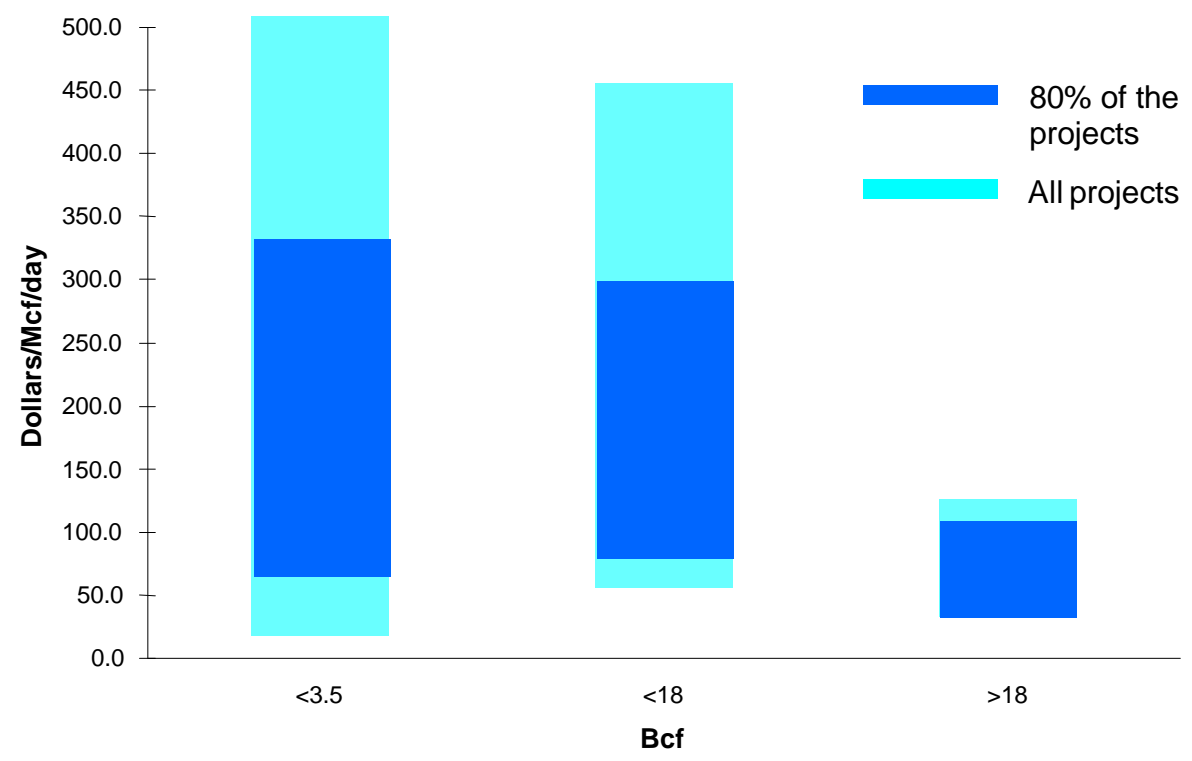

No. of projects $=41$

Median costs for withdrawal rates for capacity sizes: $<3.5 \mathrm{Bcf}=\$ 150 / \mathrm{Mcf} /$ day $<18 \mathrm{Bcf}=\$ 140 / \mathrm{Mcf} /$ day $>18 \mathrm{Bcf}=\$ 100 / \mathrm{Mcf} / \mathrm{day}$

Figure 3-3. Depleted Field Investment Cost per Unit Withdrawal Rate.

RSI-835-99-087

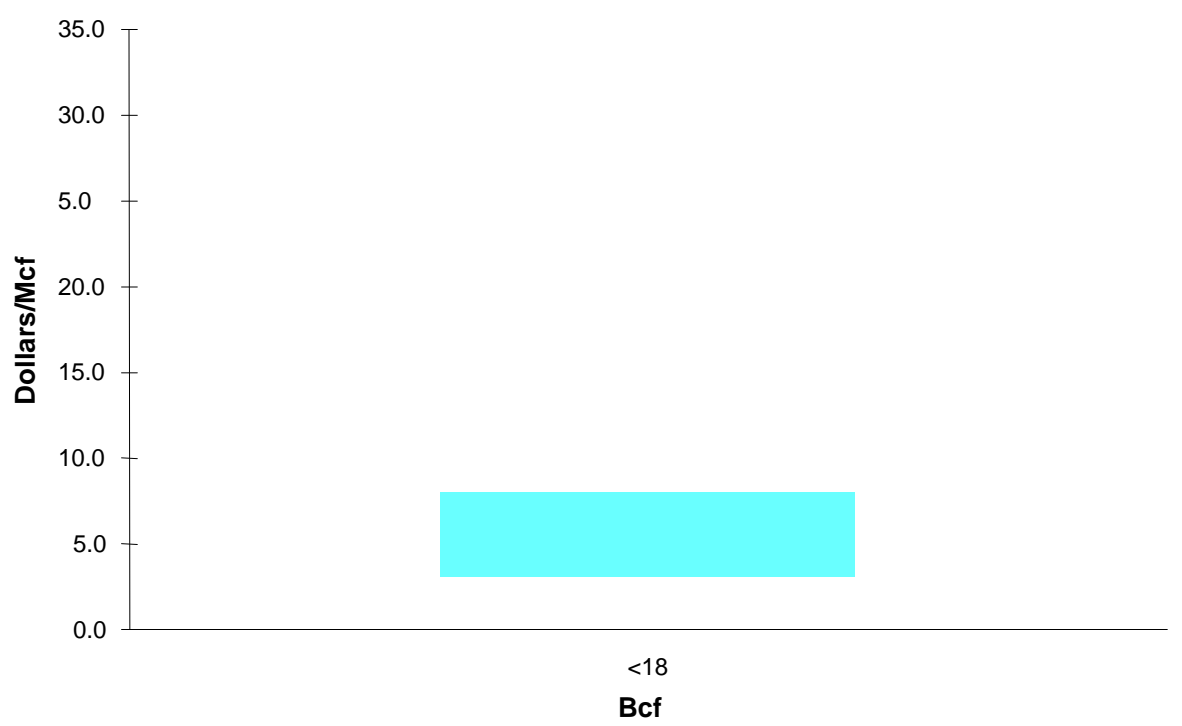

No. of projects $=3$

Median costs per capacity size: $<18 \mathrm{Bcf}=\$ 4 / \mathrm{Mcf}$

Figure 3-4. Aquifer Storage Investment Cost per Unit Working Gas Volume. 


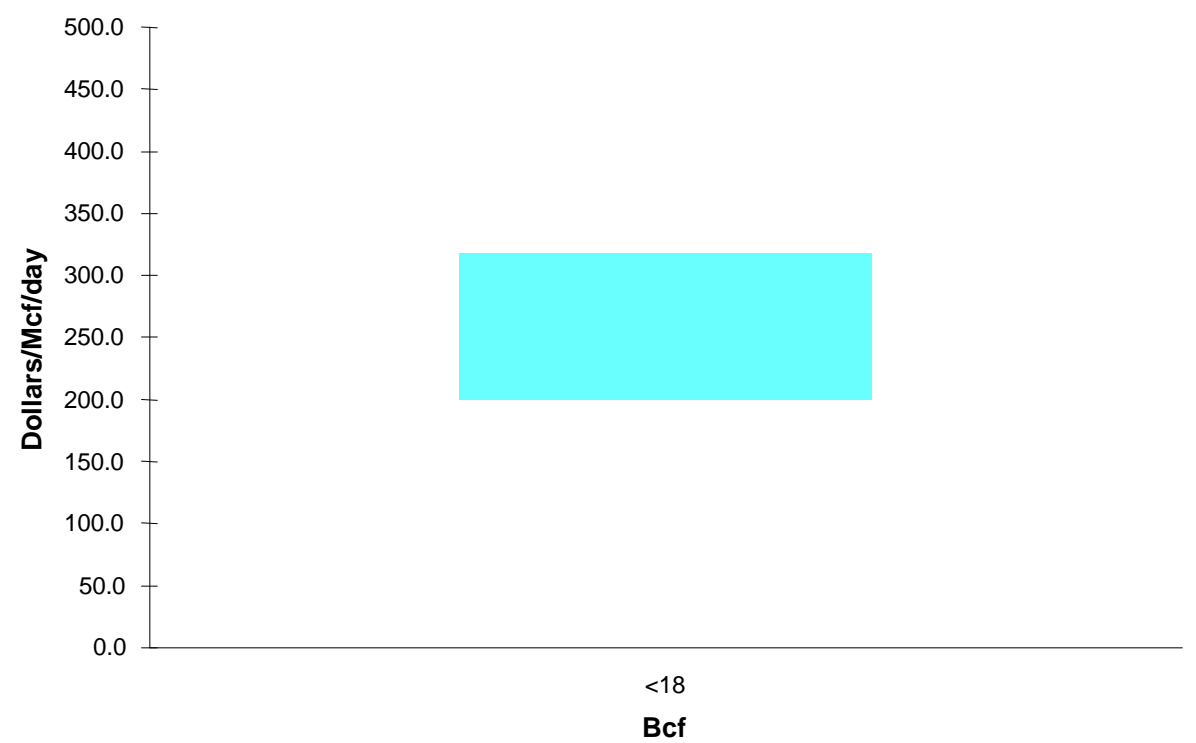

No. of projects $=3$

Median costs per withdrawal rate for capacity size: $<18 \mathrm{Bcf}=\$ 290 / \mathrm{Mcf} / \mathrm{day}$

Figure 3-5. Aquifer Storage Investment Cost per Unit Withdrawal Rate.

RSI-835-99-089

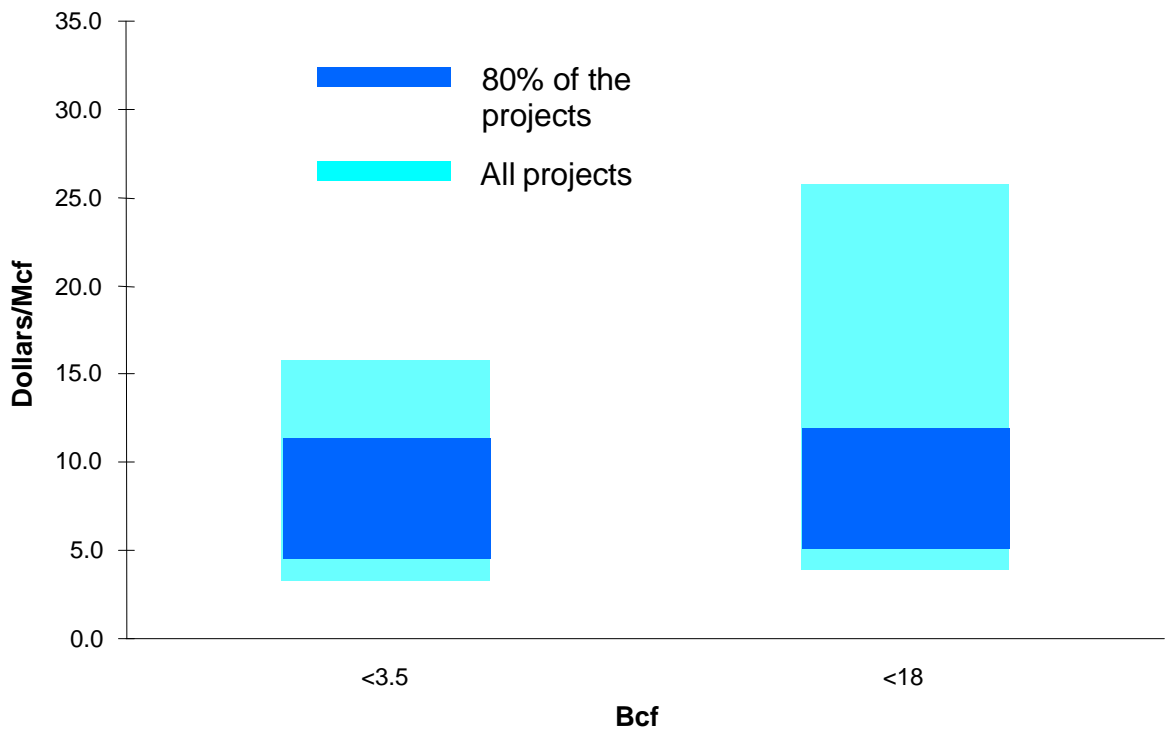

No. of projects $=24$

Median costs for capacity sizes:

$<3.5 \mathrm{Bcf}=\$ 8.6 / \mathrm{Mcf}$

$<18 \mathrm{Bcf}=\$ 8.2 / \mathrm{Mcf}$

Figure 3-6. Salt Cavern Investment Cost per Unit Working Gas Volume. 


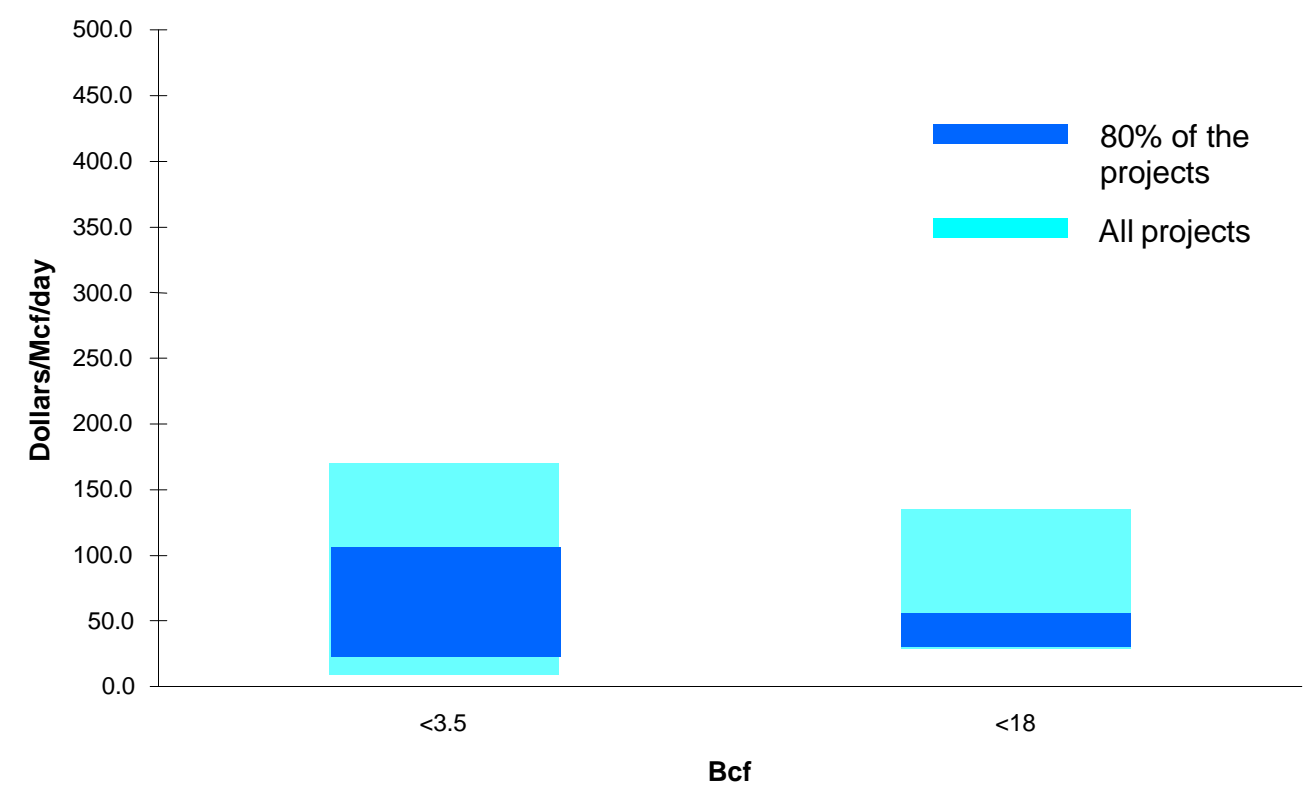

No. of projects $=24$

Median costs per withdrawal rates for capacity sizes: $<3.5 \mathrm{Bcf}=\$ 52 / \mathrm{Mcf} / \mathrm{day}$ $<18 \mathrm{Bcf}=\$ 57 / \mathrm{Mcf} /$ day

Figure 3-7. Salt Cavern Investment Cost per Unit Withdrawal Rate.

To get a better feeling for the most likely cost, a second grouping of projects, including 80 percent of the total number of projects, are represented by the dark bar. The dark bar shows the cost range if 10 percent of the storage projects with the highest and lowest cost are excluded.

The investment cost data are summarized in Tables 3-1 and 3-2. The main conclusion that can be drawn from this information is that the cost of storage depends to a large extent on the utilization of the storage. If the need is a seasonal storage with a large working gas capacity, then depleted fields and aquifers offer the lowest cost. On the other hand, if high withdrawal rates are needed for peaking services, then salt caverns offer the lowest cost.

Table 3-1. Summary of Median Size and Investment Cost per Unit Working Gas Volume

\begin{tabular}{||l|c|c|c||}
\hline \multicolumn{1}{|c|}{ Type } & $\begin{array}{c}\text { No. of } \\
\text { Projects }\end{array}$ & $\begin{array}{c}\text { Median } \\
\text { Size } \\
\text { (Bcf) }\end{array}$ & $\begin{array}{c}\text { Median } \\
\text { Cost } \\
\text { (\$/Mcf) }\end{array}$ \\
\hline \hline Aquifer & 3 & 9 & 4.0 \\
\hline Depleted Field & 41 & 6 & 3.3 \\
\hline Salt Cavern & 24 & 5 & 8.3 \\
\hline
\end{tabular}




\section{Table 3-2. Summary of Median Size and Cost per Unit Withdrawal Rate}

\begin{tabular}{||l|c|c|c||}
\hline \multicolumn{1}{|c|}{ Type } & $\begin{array}{c}\text { No. of } \\
\text { Projects }\end{array}$ & $\begin{array}{c}\text { Median } \\
\text { Size } \\
\text { (Mcf/Day) }\end{array}$ & $\begin{array}{c}\text { Median } \\
\text { Cost } \\
\text { (\$/Mcf/Day) }\end{array}$ \\
\hline \hline Aquifer & 3 & 81 & 292 \\
\hline Depleted Field & 41 & 61 & 137 \\
\hline Salt Cavern & 24 & 506 & 55 \\
\hline
\end{tabular}

For salt caverns, there is a link between the high cost for working gas and the high cost for deliverability. For depleted fields, it is often the demand for high deliverability that causes an increased cost for working gas due to more wells and more compressor power.

It also has to be kept in mind that cavern storage can be cycled several times per year, which essentially increases the available working gas capacity. If the storage is located where this multiple-cycling capability can be utilized, it will decrease the unit cost for the available working gas volume considerably. There is a clear trend in the United States for an increasing demand for cavern storage because of the high flexibility and lower cost for deliverability. 


\subsection{IDENTIFICATION AND SELECTION OF TWO GEOLOGIC CASES}

\subsection{OVERVIEW}

Figure 4-1 illustrates the major pipelines and salt basins in the United States, as well as the outcrops of Precambrian and Premesozoic rocks. The latter are candidate formations for LRC. Clearly, sites for LRC are principally in the East.

Two areas in the eastern United States were selected for LRC assessment: New England and the Southeast area. These two areas do not have the potential for conventional storage within or reasonably close to their market areas and are in primarily igneous and metamorphic geologic terrain. In addition, they are both at the eastern end of the national gas transmission system. Both of these areas depend upon LNG for a portion of their supply to meet peak-day (needle peaking) needs. Both areas would benefit greatly from market area, multicycle cavern storage.

Geological data were collected from published sources and summarized to portray the geology in and around each of the two selected areas. The locations of pipelines supplying each area were plotted on the geological maps.

The geology of the United States East Coast is almost entirely igneous and metamorphic terrain except for coastal plain sedimentary cover in the Southeast and portions of the Upper East Coast. None of the coastal plain sediments have been found to be useful for gas storage. There is only one reservoir storage facility on the East Coast located in the western part of the state of Maryland - the Accident Field with 15.3 billion cubic feet (bcf) of working gas, 62 bcf total capacity. The two regional areas studied are in crystalline igneous or metamorphic rocks adjacent to major supply pipelines and in close proximity to city gates. Both sites are described in more detail below.

\subsection{BEDROCK GEOLOGY OF NEW ENGLAND}

The geology of New England is both complex and diverse. Major geologic features of the area are summarized below and are illustrated in Figure 4-2.

\subsubsection{Regional Geology}

Eastern Massachusetts is composed of two terrains which differ in stratigraphy, metamorphism, and plutonism. These are the Nashoba zone and the Milford-Dedham zone. The Nashoba zone, which is bounded on the northwest by the Clinton-Newbury fault and on the 


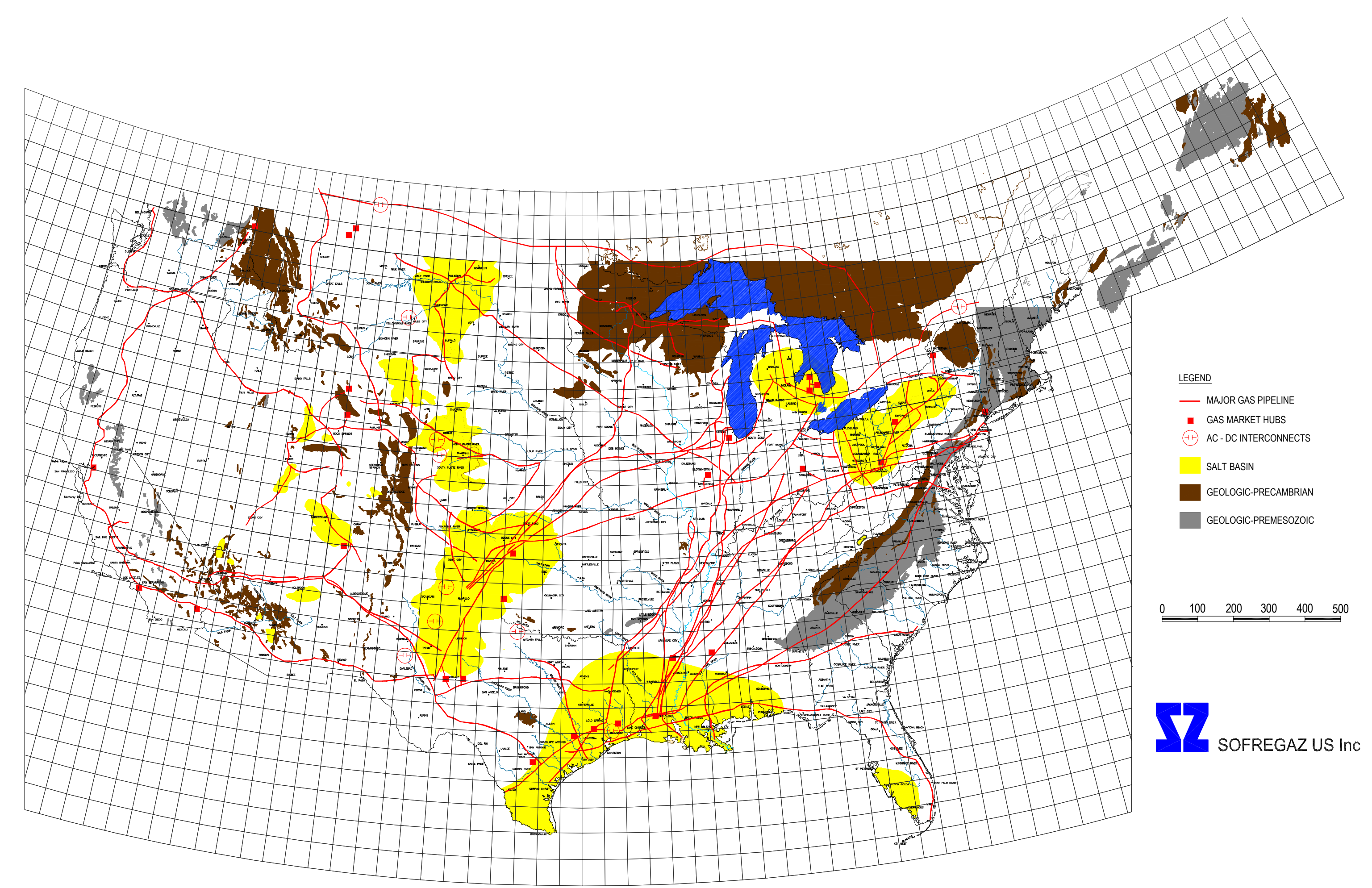

Figure 4-1. Major Pipelines, Salt Basins, and Precambrian and Premesozoic Outcrops in the United States. 


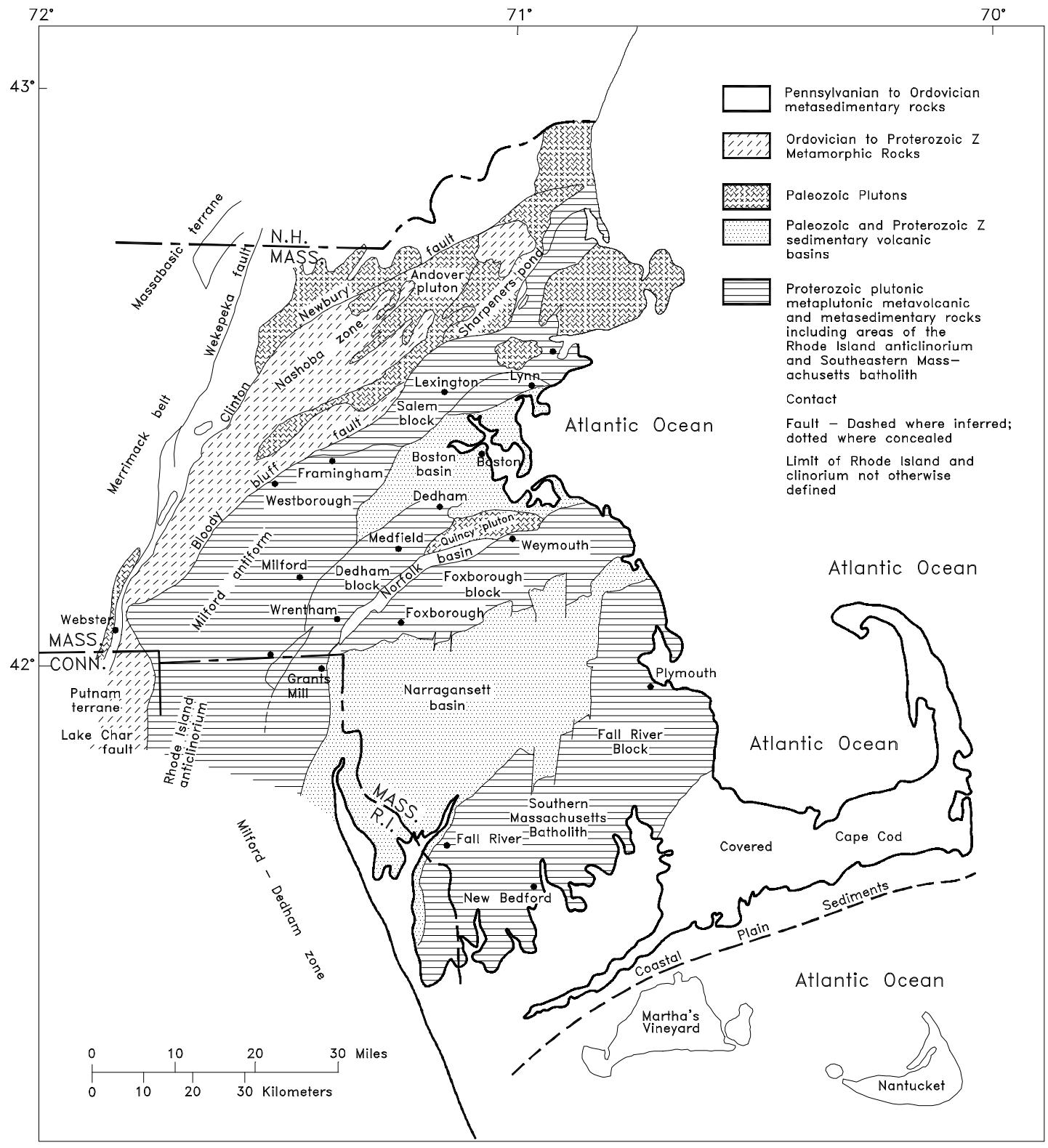

Figure 4-2. Index Map and Major Structural Features of Eastern Massachusetts (After Goldsmith [1987]). 
southeast by the Bloody Bluff fault, is a high-grade metamorphic belt composed of steeply dipping Proterozoic $\mathrm{Z}$ age schist, paragneiss, and rocks intruded by Ordovician, Silurian, and Devonian age plutons. The Milford-Dedham zone, which is bounded on the west and northwest by the Bloody Bluff fault and on the east by an offshore extension of the Meguma terrain of Nova Scotia, consists of mostly crystalline Proterozoic $\mathrm{Z}$ age plutonic and metamorphic basement rock which have been intruded by younger Proterozoic $\mathrm{Z}$ granite and granodiorite batholiths.

Nashoba Zone

The Nashoba zone is a northeast trending belt approximately 25 kilometers wide and 100 kilometers long. The Clinton-Newbury fault, which defines the northwestern boundary of the zone, extends from the Massachusetts-Connecticut border to the Gulf of Maine. The southeastern boundary of the Nashoba zone, which is defined by the Bloody Bluff fault, approximately parallels the Clinton-Newbury fault and is located 20 kilometers northwest of the center of the city of Boston. The Nashoba zone appears to be synformal with only a few large-scale folds identified; however, the zone contains many small-scale easterly trending folds. The zone is cut by many northeast-trending longitudinal faults which are post-Silurian, possibly Mesozoic in age. Older faulting within the zone and in the Clinton-Newbury fault system are west-dipping, low-angle thrust and reverse faults which are possibly of Acadian age. The younger faulting tends to be steeply dipping and is characterized by brecciation and gouge along the fault trace, while the older faults are characterized by mylonite or microbrecciation.

The Nashoba zone lies in a narrow belt of high-grade metamorphism, which consists of pelitic rocks of the Nashoba Formation, Fish Brook Gneiss, Shawsheen Gneiss, Tadmuck Brook Schist, and the Marlboro Formation. These rocks are of Proterozoic Z age (580-730 million years) and represent sedimentation and volcanism within a basin forming adjacent to a volcanic arc. The pelitic rocks of the Nashoba, Shawsheen, and the eastern part of the Tadmuck Brook contain sillimanite-muscovite and sillimanite-orthoclase mineral assemblages, while the pelitic rocks of the Marlboro and western part of the Tadmuck Brook contain mineral assemblages of staurolite and andalucite. The rocks assemblage described have been placed in the sillimanitealmadine-orthoclase subfacies of the highly metamorphosed almadine-amphibolite facies. The mineral associations of the Nashoba belt suggest that these rocks recrystalized at a temperature of $625-650^{\circ} \mathrm{C}$ and a pressure of 6 kilobars, indicating a burial depth of approximately 23 kilometers. In the northern portion of the Nashoba zone, evidence suggests that additional thermal metamorphism occurred contemporaneous with the emplacement of the Ordovician age Andover Granite. The later emplacement of the Sharpners Pond Diorite during the Silurian and a Devonian age Andover Granite appears to have little additional metamorphic effect.

The intrusive rocks of the Nashoba zone range in age from Ordovician to Devonian and are largely massed in the northern portion of the zone. The Andover Granite intruded in two phases: the Ordovician age Andover Granite (450 million years) covers an area of 
approximately 200 square kilometers and is a light-colored, muscovite-garnet-bearing gneissic granite which intruded the formations of the Nashoba zone at all scales. The Sharpners Pond Diorite (430 million years) covers an area of approximately 150 square kilometers and is an hornblende diorite to granodiorite. The Straw Hollow Diorite and Assabet Quartz Diorite, which appear to be slightly older than the Sharpners Pond Diorite, cover an area of approximately 26 square kilometers and are gray to green colored, weakly foliated hornblende diorite to granodiorite. The Devonian age Andover Granite (410 million years) is a light-colored nongneissic binary granite, and in addition, a nongneissic pegmatitic granite which intrudes both the gneissic Andover Granite and the Sharpners Pond Diorite.

\section{Milford-Dedham Zone}

The Milford-Dedham zone has been broken by normal and reverse faults into upthrown blocks of Proterozoic age plutonic and metamorphic basement rock and downthrown blocks containing sedimentary and volcanic cover rocks of Proterozoic Z, Cambrian, SilurianDevonian, Pennsylvanian, Triassic, and Jurassic age. The major upthrown blocks are the Milford antiform, the Salem block, and the southeastern Massachusetts batholith, which is subdivided into the Dedham, Foxborough, and Fall River blocks. The downthrown blocks are the Newbury, Middleton, Boston, Norfolk, Bellingham, and Narragansett basins.

The Milford antiform consists of gneissic plutonic rocks of the Proterozoic Z Sterling Plutonic Suite, Milford Granite, metasedimentary and metavolcanic rocks of the Plainfield and Westboro Formations and the Blackstone Group. The metasedimentary and metavolcanic formations are largely in the amphibole facies of metamorphism and are thought to have undergone metamorphism prior to the intrusion of the plutonic rocks. In general, the Milford antiform is divided into two areas of varying deformation. An extension of the Northern Border fault, which is the boundary between the Milford antiform and the Boston basin, separate the variably deformed amphibole facies plutonic, quartzitic, and paragneissic rocks of the west from the fractured, brittlely deformed greenschist facies plutonic, metasedimentary, and metavolcanic rocks.

The Milford Granite is located near the town of Milford and occupies an area of approximately 100 square kilometers. The Milford is divided into two phases: a light-colored pink granite and a darker-colored granodiorite. The Milford Granite, along with the Esmond Granite, form the core of the Milford antiform and are relatively undeformed.

The Salem block, which is located north of the Milford antiform, consists primarily of Proterozoic $\mathrm{Z}$ age mafic plutonic rocks, mafic to felsic metavolcanic rocks, and minor metasedimentary rocks. These rocks have been intruded by the younger Proterozoic $\mathrm{Z}$ age Dedham Granite and Topsfield Granodiorite and by early and middle Paleozoic alkalic granite and gabbro. The metavolcanic and metasedimentary rocks contain assemblages typical of the amphibole facies metamorphism, while the Dedham Granite and Topsfield Granodiorite exhibit metamorphism no higher than the greenschist facies. The Paleozoic age Peabody Granite forms 
the core of the Peabody pluton, which has an area of approximately 50 square kilometers. The Peabody Granite is a light-gray to green-colored, weathered granite consisting of alkali feldspar, quartz, and ferrohornblende. The Cape Ann pluton consists of the OrdovicianSilurian age Cape Ann Granite, the Beverly Syenite, and the Squam Granite. Together, these members occupy an area of approximately 385 square kilometers. The Cape Ann Granite is a grayish-green, medium- to coarse-grained granite to quartz syenite. The term Beverly Syenite refers to rocks similar to the Cape Ann but completely absent of quartz. The Squam Granite is a gray to brown, fine- to medium-grained, porphyritic alkalic granite and occupies only an area of 5 square kilometers within the overall Cape Ann Complex.

The Dedham, Foxborough, and Fall River blocks are located southeast of the Milford antiform and Salem block and form the Proterozoic Z age southeastern Massachusetts batholith. The Dedham and Foxborough blocks consist almost entirely of plutonic basement rock; metasedimentary and metavolcanic rocks are rare and are only found as inclusions within the plutonic rock. The plutonic rocks of the Dedham and Foxborough blocks are similar in composition and texture as the Proterozoic Z plutonic rocks of the Salem block, except as a whole, they are significantly less deformed, fractured, or altered. The Fall River block is separated from the Foxborough block by the Narragansett basin. The plutonic rocks are similar in composition and texture to that of the Foxborough block. The Fall River block contains significantly more metasedimentary and metavolcanic basement rock, which grade from the low-grade greenschist facies of metamorphism in the northern part of the block to a high-grade amphibole facies in the south.

The Newbury basin is a small wedge-shaped lenticular basin located between the Nashoba zone and the northern part of the Salem block. The basin is believed to have formed as a graben within the Bloody Bluff fault complex during Paleozoic time. The strata is unmetamorphosed Silurian-Devonian marine sediments and volcanic rocks, which have subsequently been overturned. The Middleton basin lies in the same structural zone as the Newbury basin and includes an area no greater than 6 kilometers long and 0.5 kilometer wide. This basin is filled with Triassic-Jurassic redbed deposits.

The Boston basin, which is separated from the Milford antiform and Salem blocks on the north and west by the Northern Border fault and the Dedham and Foxborough blocks on the south by the Mount Hope and Blue Hills faults, contains unmetamorphosed Proterozoic Z sedimentary and volcanic rocks of the Boston Bay Group overlying basement rocks of the Milford antiform, Salem, and Dedham blocks. The Northern Border fault is a reverse fault approximately 38 kilometers long that has thrust the Salem block and Melrose subblock southeastward over the Boston Bay Group. The throw on this fault is estimated to be 1,300 meters. The Mount Hope fault, which is the northeastern border of the Dedham block, is believed to be a northward-directed thrust fault which has subsequently been rotated to near vertical. The maximum throw on the fault is estimated at 350 meters. The Blue Hill fault, which forms the boundary between the Boston Basin and the Foxborough block, is thought to be 
a northward-directed thrust fault which has been subsequently rotated and tilted. The throw on this fault is estimated at 5,000 meters. The Quincy pluton is located on the southern border of the Boston basin and is composed of the Silurian-Ordovician age Quincy Granite and Blue Hills Granite. The pluton occupies an area of approximately 55 square kilometers and is described as a light brown to pink, fine- to coarse-grained hornblende granite.

The Norfolk basin is located between the Dedham and Foxborough blocks and is similar to the Narragansett basin in that it is composed largely of unmetamorphosed Pennsylvanian age marine and nonmarine sediments overlying Proterozoic Z basement rocks. The basin is fault bounded with throws estimated at 400 meters.

The Bellingham basin, which is located on the Massachusetts-Rhode Island border, is a fault-bounded graben composed primarily of slightly metamorphosed (greenschist facies) Pennsylvanian age nonmarine pebbles to conglomeratees clastic deposits.

The Narragansett basin is located between the Foxborough and Fall River blocks and is composed largely of the unmetamorphosed fine- to medium-grained Pennsylvanian age marine and nonmarine sedimentary rocks. The Pennsylvanian rests nonconformably on the Proterozoic basement rocks. The basin is estimated to be 2,000 meters thick with the maximum subsidence occurring at the northern and southern borders.

\subsubsection{Potential Storage Sites}

Numerous potential storage sites for LRC exist in the Northeast. From a geomechanics standpoint, evaluation of the Rock Mass Rating (RMR) is perhaps the most expedient method for determining site suitability. Other important site selection factors include pipeline access, ease of permitting, groundwater conditions, local faulting, and access.

\subsection{BEDROCK GEOLOGY OF THE SOUTHEAST AREA}

The geology of the Southeast United States is nearly as diverse as the Northeast. The major geologic features of the area are summarized below and illustrated in Figure 4-3.

\subsubsection{Regional Geology}

Northern Georgia encompasses four geographical regions: Cumberland Plateau, Valley and Ridge, Blue Ridge Mountains, and Piedmont Plateau. These geographical regions, except the Piedmont Plateau, are included as part of the Appalachian Mountains. The Cumberland Plateau, which is located in the extreme northwestern corner of the state, is characterized by narrow infertile valleys bordered by high, steep ridges. The Valley and Ridge region lies to the east of the Cumberland Plateau and is characterized by wide, flat fertile valleys separated by 


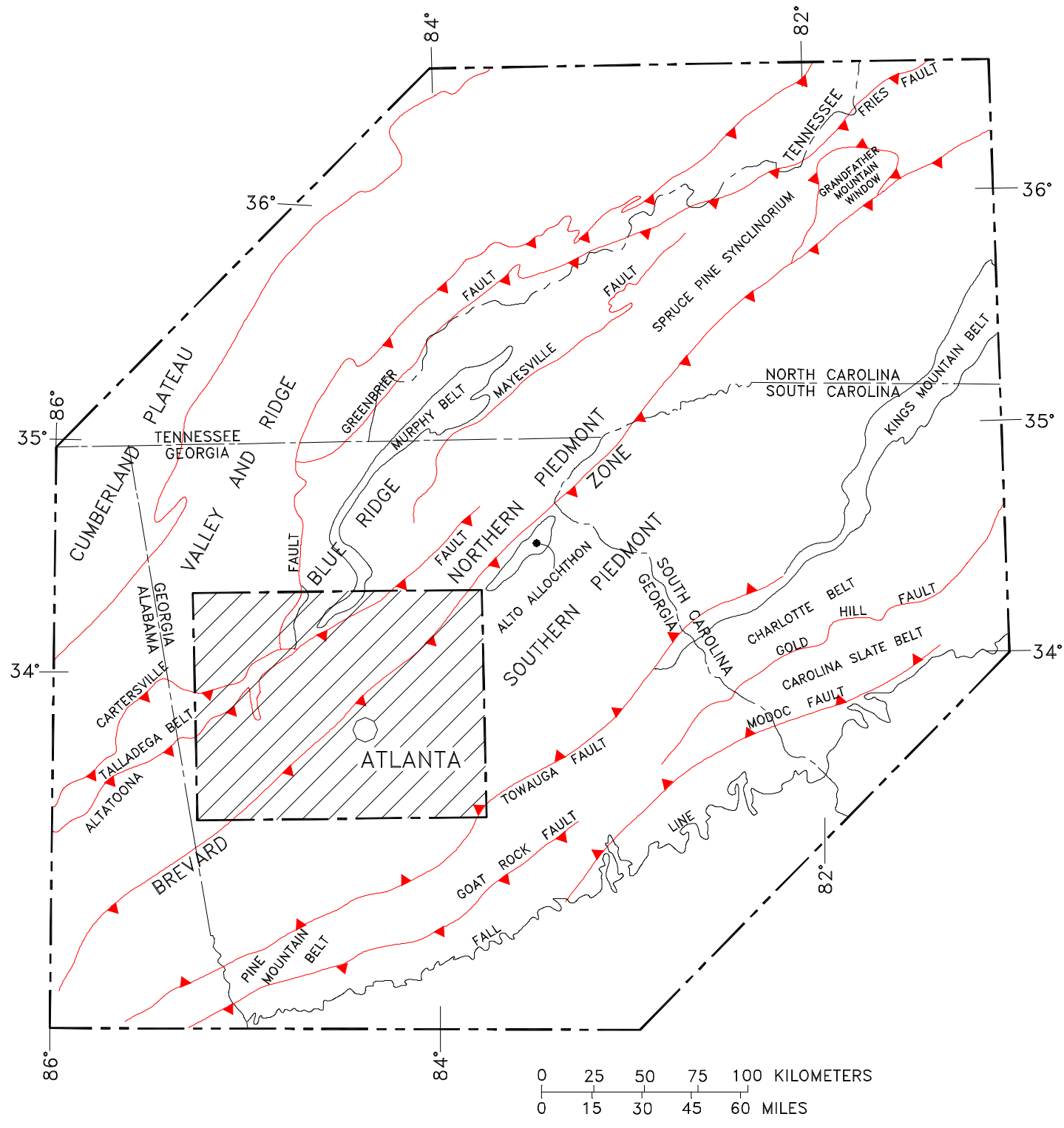

Figure 4-3. Regional Location Map Showing Boundaries of the Greater Atlanta Regional Map and Regional Setting of Map Area (After McConnell and Costello [1982]). 
narrow, steep-sided ridges. The Blue Ridge Mountains region is characterized by rounded forested mountains separated by narrow valleys underlain by crystalline bedrock. The Piedmont Plateau makes up most of the northern one-half of the state and is characterized by rolling hills also underlain by crystalline bedrock.

Rocks of the Atlanta region area are divided into three major geologic provinces: Valley and Ridge, Blue Ridge, and Piedmont. The Valley and Ridge Geologic Province is composed of unmetamorphosed to weakly metamorphosed (greenschist facies) Paleozoic age rocks of the foreland thrust and fold belt. The Blue Ridge Geologic Province is composed of metamorphosed Proterozoic Y basement rocks and Proterozoic Z age to early Paleozoic age metasedimentary rocks. The Piedmont Geologic Province is composed of Proterozoic $\mathrm{Z}$ age to early Paleozoic age metasedimentary and plutonic rocks. The Piedmont Geologic Province is subdivided into the Northern and Southern Piedmont Provinces and is composed of Proterozoic Z to early Paleozoic metasedimentary, metavolcanic, and plutonic rocks.

\section{Valley and Ridge Province}

The Valley and Ridge Province is defined as that region located between the Cumberland Plateau and the Blue Ridge Mountains. The boundary between the Valley and Ridge Province and the Blue Ridge Province corresponds with the trace of the Cartersville fault. Rocks ranging in age from Lower Cambrian to Pennsylvanian are present in this region, but only rocks of Lower Cambrian age are present in the immediate Atlanta area. The oldest rocks in the province are represented by the Chilhowee Group, Cochran Formation, Nichols Formation, Wilson Ridge Formation, and Weisner Formation.

The Wilson Ridge and Weisner Formations are the only members of the Chilhowee Group present in the Atlanta area. Rocks of the Wilson Ridge Formation are described as fine- to coarse-grained, moderately well-sorted orthoquartzite. Overlying the Wilson Ridge is the Weisner Formation, which is composed of rocks described as very fine- to fine-grained orthoquartzite, cross-bedded fine- to coarse-grained orthoquartzite, conglomerate and grayishgreen mudstone.

Overlying the Weisner is the Shady Dolomite, which is described as a thin, dark gray to black, fine-grained dolomite having paper-thin shale lamellae. The Rome Formation overlies the Shady Dolomite and is described as a red- to green-colored, fine-grained, slight calcareous sandstone with some thin layers of limestone present.

\section{Blue Ridge Province}

The Blue Ridge Province is defined as those rocks present between the Cartersville fault on the north and the Allatoona fault on the south. The Blue Ridge portion of the Atlanta region area is dominated by two structural features: the Salem Church anticlinorium and the Murphy synclinorium. 
The Salem Church anticlinorium is composed of the Proterozoic Y (1,000 million years) age Corbin Gneiss Complex and the Proterozoic Z age Ocoee SuperGroup: Snowbird Group, Walden Creek Group, and Great Smoky Group. Rocks comprising the Corbin Gneiss Complex form the core of the Salem Church anticlinorium and consists of a paragneiss described as a coarsegrained, quartz-monzonitic orthogeneiss- medium- to coarse-grained, orthoclase-mica gneiss and metaigneous granite and granodiorite. The Snowbird Group consists of the Pinelog Formation, which unconformably overlies the Corbin Gneiss. The Pinelog Formation is described as poorly sorted quartz-pebble metaconglomerate, metasandstone, metasiltstone, and metashale. Rocks of the Pinelog Formation are erosional in origin and are derived from the granitic Corbin Gneiss facies. Overlying the Pinelog is the Wilhite Formation of the Walden Creek Group, which consists of a think sequence of metasandstone, sandy marble, and calcareous metasiltstone. The Great Smoky Group is the uppermost member of the Ocoee SuperGroup and consists of the Etowah Formation, Sweetwater Creek Formation, and the Dean Formation. The Etowah Formation lies conformably on the Wilhite Formation and consists of a monotonous sequence of interlayered metasandstones and meta-argillite with small lenses of calc-silicate granofels. Overlying the Etowah is the Sweetwater Creek Formation which consists of poorly sorted coarse-grained conglomeritic metasandstone with thin interbeds of graphitic phyllite. The Dean Formation is the uppermost member of the Great Smoky Group and consists of a moderately well sorted quartz-pebble metaconglomerate.

Within the Murphy synclinorium, the Dean Formation is overlain by Lower Paleozoic age rocks of the Murphy Belt Group: Nantahala Formation, Brasstown Formation, Murphy Marble, Marble Hills Hornblende Schist, and the Mineral Bluff Formation. The Nantahala Formation is predominantly a carbonaceous phyllite to laminated argillite with interbeds of fine- to medium-grained metasandstone. Overlying the Nantahala is the Brasstown Formation which consists of interlayered gray schists and micaceous quartzites. The Murphy Marble, which is a fine- to medium-grained calcitic to dolomitic marble, overlies the Brasstown and is a high-quality commercial quarried commodity. The Murphy Marble grades upward culminating in the Marble Hills Hornblende Schist. A relatively thin transition zone is considered the formation boundary. The Mineral Bluff Formation is the uppermost member of the Murphy Belt Group and is described as a thick sequence of pelitic rocks with included garnet-quartzsericite schist and pure-sericite schist.

\section{Northern Piedmont Province}

The Northern Piedmont Province includes all rocks lying between the Allatoona fault and the Brevard fault and includes the late Precambrian age New Georgia and Sandy Creek Groups. In the Atlanta region area, the New Georgia Group is characterized by the dominance of metavolcanic rocks over metasedimentary rocks. The Sandy Creek Group is the opposite and is characterized by the dominance of metasedimentary rocks over metavolcanic rocks.

The New Georgia Group is exposed in outcrop along a belt 22 kilometers wide and 210 kilometers long and contains most of the base and precious metal deposits in the region. The New 
Georgia Group is composed of intermingled beds of metamorphosed felsic and mafic volcanic rocks, plutonic rocks, and a small amount of sedimentary rocks. Metamorphism and intense deformation have obliterated the original sedimentary and volcanic textures, making the internal stratigraphy of the New Georgia Group very difficult. However, portions of the New Georgia Group in the Atlanta region area are well known and have been extensively studied. These stratigraphic units and areas include the Mud Creek Formation in the Villa Rica area, the Pumpkinvine Creek Formation to the northeast of the Villa Rica area, and the Univeter Formation near the town of Univeter.

The Mud Creek Formation is composed of garnetiferous, hornblende-plagioclase amphibolite gneiss interlayered with garnet-biotite schist and gneiss and banded-magnetite quartzite. The Pumpkinvine Formation is composed of hornblende-quartz-plagioclase gneiss interlayered with biotite-muscovite-plagioclase gneiss and amphibolite. The Univeter Formation is composed of a sequence of amphibolite, hornblende gneiss, garnet-biotite-muscovite schist, garnet-chlorite schist, and banded-magnetite quartzite.

The Sandy Springs Group overlies the New Georgia Group and represents the most areally extensive rock group in the Northern Piedmont Province. The Sandy Springs Group is divided into rocks of the eastern belt and the western belt. The Sandy Springs (eastern belt) consists of three formations: Powers Ferry Formation, Chattahoochee Palisades Quartzite, and Factory Shoals Formation. The Powers Ferry Formation is the oldest unit in the Sandy Springs Group and is composed of interlayered gneiss, schist, and amphibolite. Overlying the Powers Ferry is the Chattahoochee Palisades Quartzite, which is described as a massive white to yellowish, sugary to vitreous quartzite containing mica and garnet. Overlying the Chattahoochee Palisades is the Factory Shoals Formation, which is composed of garnet-biotite-oligoclase, which varies from a kyanite-quartz schist to a staurolite-muscovite-quartz schist.

The Sandy Springs (western belt) consists of three formations: Dog River Formation, Andy Mountain Formation, and Bill Arp Formation. The Dog River Formation is composed of interbedded muscovite-biotite-quartz-feldspar gneiss, garnet-muscovite schist, amphibolite, and thin beds of magnatite quartzite. Overlying the Dog River is the Andy Mountain Formation, which is composed of garnet-muscovite-quartz schist and sugary quartzite. The Bill Arp Formation is the uppermost member of the Sandy Springs (western belt) Group and consists of interlayered garnet-biotite-muscovite-plagioclase-quartz schist and metagraywacke.

\section{$\underline{\text { Southern Piedmont Province }}$}

The city of Atlanta is located within the Southern Piedmont Province. The Southern Piedmont Province is defined as those rocks lying between the Brevard fault and the Atlantic Coastal Plain and includes late Proterozoic Z to early Paleozoic rocks of the Atlanta Group. The similarity of the rock units and stratigraphic sequence indicates the rocks of the Atlanta Group are equivalent to those of the New Georgia and Sandy Springs Group. The Southern Piedmont Province has been complicated by intrusion of late Paleozoic plutons but is currently accepted 
that the rocks south of the Brevard fault were deposited in similar environments as the rocks north of the Brevard fault. In general, the Camp Creek and Big Cotton Indian Formations of the Southern Piedmont are equivalent to the New Georgia Group. The Clarkston, Stonewall, Wahoo Creek, Clairmont, Norcross Gneiss, and Promise Land Formations of the Southern Piedmont are equivalent to the Powers Ferry Formation of the Sandy Springs Group. The Lanier Mountain Quartzite of the Southern Piedmont is equivalent to Chattahoochee Palisades Quartzite, and the Norris Lake Schist is equivalent to the Factory Shoals Formation.

\section{$\underline{\text { Plutonic Rocks }}$}

Post Grenville (Proterozoic Y) age-intrusive rocks are generally limited to the Piedmont Provinces, although numerous pegmatites occur in the Blue Ridge Province. Plutons of Grenville age or older are limited to the Corbin Gneiss Complex in the Blue Ridge Province. Paleozoic-intrusive rocks in the Piedmont Provinces are divided into three categories: premetamorphic, presynmetamorphic, and postmetamorphic. Paleozoic metamorphism is not exactly known or defined but has been interpreted to have occurred at approximately 265 million years.

Intrusive rocks in the Piedmont Provinces that were emplaced prior to metamorphism and subsequent deformation have lost most of their original fabric and texture; however, several premetamorphic plutons are recognized in the Atlanta region area. The Villa Rica Gneiss, Laura Lake Mafic Complex, Acworth Gneiss, Kellogg Creek Mafic Complex, and Galts Ferry Gneiss are members of the premetamorphic category north of the Brevard fault. Biotiticplagioclase gneisses of the Big Cotton Indian, Camp Creek, possibly Promise Land and Norcross Gneiss formations are premetamorphic intrusives found south of the Brevard fault.

Presynmetamorphic intrusive, like those intrusives in the premetamorphic category, retain deformational fabrics associated with Paleozoic metamorphism. However, unlike those premetamorphic plutons, presynmetamorphic intrusives, they show no direct relationship to surrounding extrusive rocks. In general, presynmetamorphic intrusives contain far more potassium and are considered as peraluminous to meta-aluminous. The Austell, Sand Hill, and Mulberry Rock Gneiss are intrusives found north of the Brevard fault while the Union City Complex is the only intrusive in this category found south of the Brevard fault.

Postmetamorphic-intrusive rocks in the Atlanta region area can be divided into two subdivisions: those emplaced 300-325 million years and those emplaced 180-230 million years. The older of the two subdivisions is represented by large felsic plutons, such as the Stone Mountain, Ben Hill, Panola, and Palmetto Granites, and are limited to the Southern Piedmont Province. These large plutons are similar in texture and composition and are characteristically medium- to coarse-grained porphyritic granites composed of biotite-muscovite-quartzplagioclase-microcline. These plutonic rocks show no metamorphic overprint or fabric deformation. Intrusives of the younger subdivision are Jurassic-Triassic age diabase dikes and 
are also limited to the Southern Piedmont Province except one small diabase dike located in the Blue Ridge Province.

\subsubsection{Potential Storage Sites}

As with the Northeast, many potential LRC sites exist in the Southeast. Again, evaluating the RMR is perhaps the most expedient method for accessing site suitability from a geomechanics perspective. The groundwater, pipeline access, ease of permitting, and access will also play important roles in siting an LRC in the Southeast. 


\subsection{CONCEPTUAL DESIGN FOR LRC}

\subsection{DESIGN PRINCIPLES}

Certain aspects of the LRC technology or technology development that were discussed in Chapter 2.0 are discussed again below in more detail to more fully explain the LRC design principles.

\subsubsection{Historical Background}

More than 10 years of research and development have been invested in the LRC concept. The development work can briefly be described by looking at the eight major steps taken during this period to advance the development of the LRC concept. A brief description of the eight major steps discussed previously in Chapter 2.0 is summarized below.

\section{- Step 1 - Conceptual Studies}

The first step consisted of basic conceptual studies and was conducted from 1987 through 1992 by a combination of Scandinavian companies, including Sydkraft, Sydgas, Swedgas, and Vattenfall. These studies principally addressed the issue of the cavern lining and its tightness to gas.

\section{- Step 2 - Experimental Tests}

During the second step, from 1990 to 1994, two concepts of gas storage in rock cavern using a water seal and storage at low temperature (chilled storage) were studied through a series of tests performed in the Röda Sten experimental rock cavern.

\section{- Step 3 - Grängesberg Pilot Plant}

A pilot plant was constructed in 1988-1989 at Grängesberg in Sweden and used for testing from 1989 through 1993. The purpose was to experiment with different linings and evaluate the effect of increasing pressure, to test the benefit of reduced storage temperature, to further investigate the feasibility of stainless steel lining, to better understand the fracture mechanism in the surrounding rock, and to test the consequence of leakage in the liner at high pressure.

\section{- Step 4 - Test Plant Result Interpretation}

The fourth step consisted of compiling and analyzing the test plant results and was completed in 1995.

\section{- Step 5 - Technical Studies}

Technical studies, such as operational conditions, siting criteria, risk analysis, modeling of sandwich wall construction, drainage system, rock mechanics studies, quality assurance, 
creation of the circulation system, and aboveground plant simplified design were implemented 1994-1995.

\section{- Step 6 - Engineering Studies}

During the sixth step, from 1994-1996, engineering work had been accomplished, including design of sandwich wall and drainage system, gas leakage detection, study of high withdrawal and injection rates, quality control, and market analysis.

\section{- Step 7 - Risk Assessment and Preliminary Design}

The seventh step, started in 1996, was completed in 1997. It addressed mostly the risk assessment and the preliminary design of the demonstration plant. These studies were carried out jointly by the present LRC partners: Gaz de France and Sydkraft.

\section{- Step 8 - Demonstration Project}

The eighth step, whose implementation was approved by the partners in October 1997, consists of building and testing a demonstration plant of industrial scale. The construction work started in the fall of 1998, and commissioning is scheduled for the beginning of 2001. The storage will be located at Skallen near Halmstad in southern Sweden. The geometric volume will be $40,000 \mathrm{~m}^{3}$ (1.4 MMcf or 250,000 bbls), which is one-half the size of a commercial cavern.

Besides development of the concept, the efforts made in cooperation with the Royal Institute of Technology in Stockholm, Sweden, and the Chalmers Institute of Technology, Gothenburg, Sweden, have contributed to the knowledge of strength and general behavior of the rock mass that is subjected to the high gas storage pressures.

\subsubsection{General Rock Mechanics Aspects}

This section will describe general rock mechanical aspects which constitute the basis for the behavior of the rock mass, and thus, the design. The presentation is related to the test plant in Grängesberg which was used for verification and development of the theories behind the LRC concept.

The general approach for the Grängesberg pilot tests was to use established and well-known methods to classify the rock mass in order to establish the rock mass parameters. The parameters were used together with rock mechanics principals for prediction of deformations. The logic chain of the approach is shown in Figure 5-1.

\subsubsection{Expected General Behavior of the Rock Mass}

The expected deformation of the rock mass in the Grängesberg Pilot Plant (see Figure 5-2) was based on the rock mechanics principles (e.g., Brown et al. [1983]; Stille [1984]). The rock mechanics approach, termed here as the "elasto-plastic" approach, is the normal approach for 
rock mechanic applications commonly used in Sweden. At low pressures, an elastic behavior is expected. At higher pressures, tensile stresses will occur, starting in the rock surface. When the strength of the rock mass is exceeded, shearing and compression takes place in the joints leading to plastic or irreversible deformations.

RSI-835-99-091

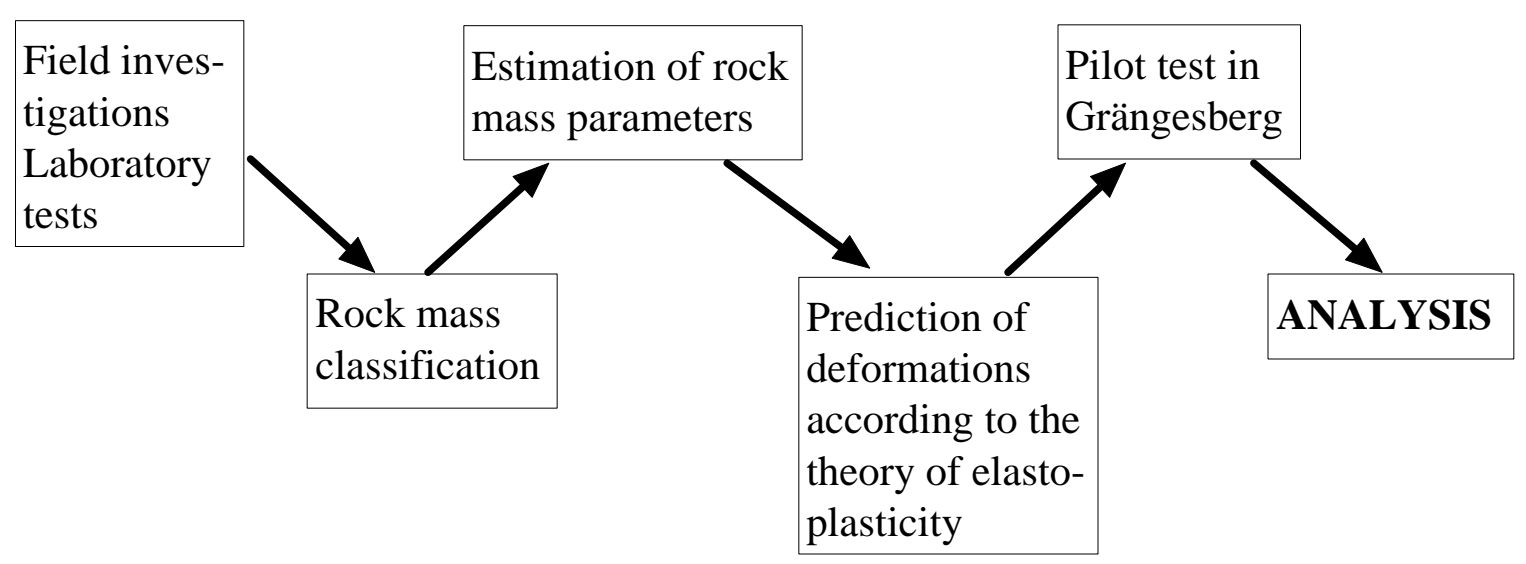

Figure 5-1. The Logic Chain of the Approach Adopted for the Grängesberg Pilot Plant Tests.

RSI-835-99-092

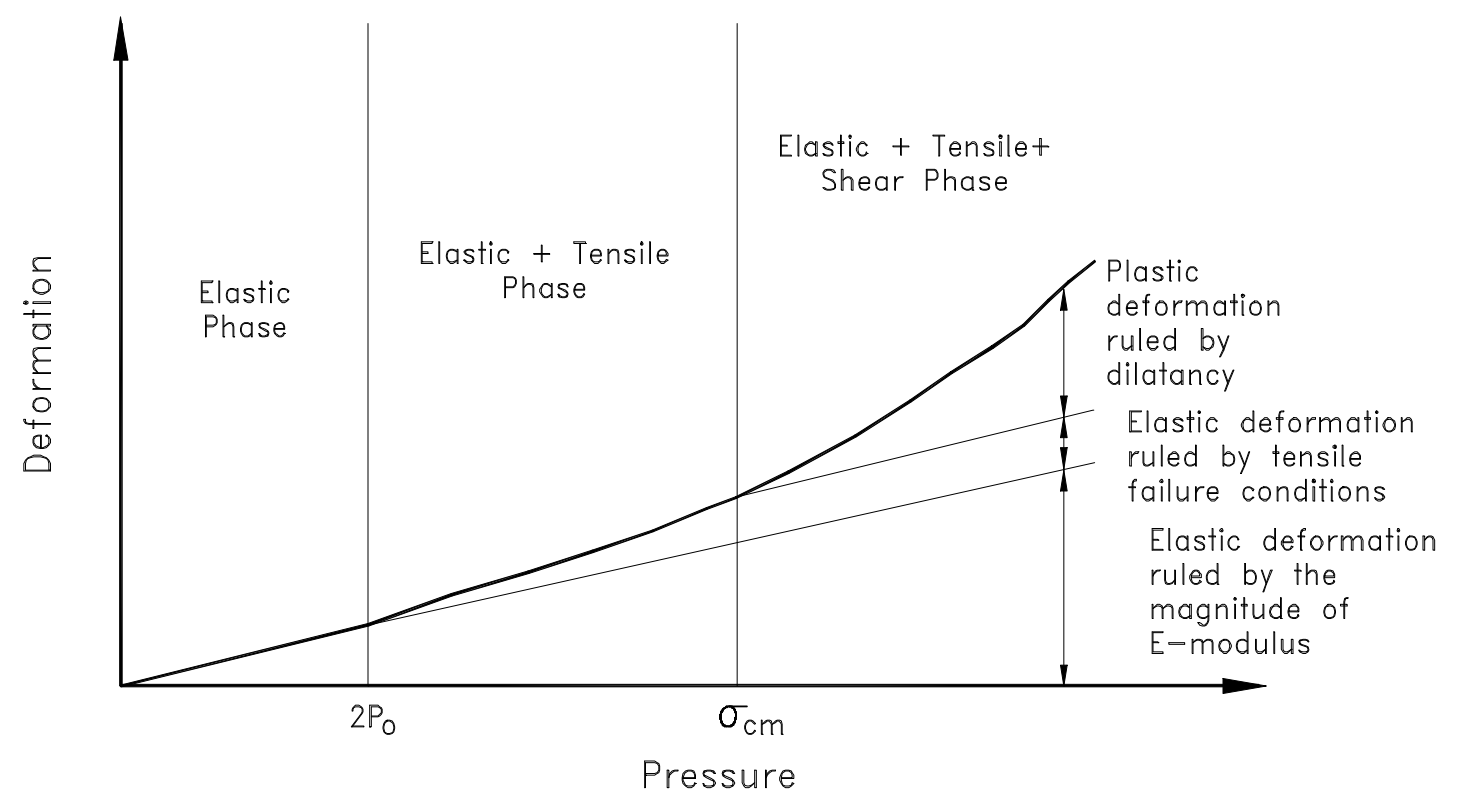

Figure 5-2. Expected Principal Elasto-Plastic Behavior of the Rock Mass. Tensile Stresses in the Rock Surface Occur at Twice the Initial In Situ Stress, $2 \mathrm{P}_{0}$ (for an Isotropic Stress Field). Plastic Deformations Occur When the Compressive Strength of the Rock Mass, $\sigma_{c, m}$, Is Exceeded. 
At high pressures, three deformation zones will develop around the cavern, as illustrated in Figure 5-3. The radius and the thickness of each zone depends on the strength of the rock mass and the initial in situ stress field. A weaker rock will result in a larger plastic zone.

RSI-835-99-093

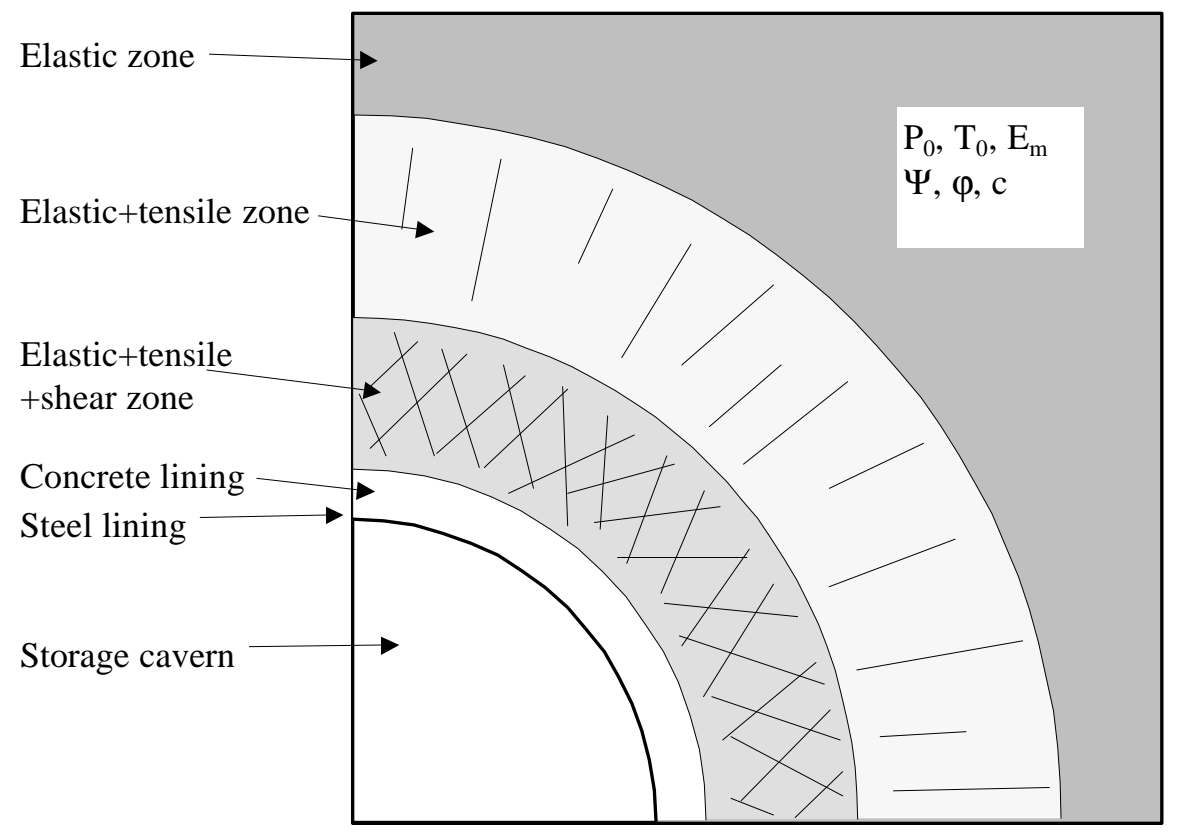

Figure 5-3. Illustration of the Different Deformation Zones Around a Pressurized LRC.

An isotropic elasto-plastic behavior is relevant when studying large volumes of a rock mass with several joint sets. This is, for example, the case for the Grängesberg Pilot Plant. If a rock mass contains only a few sets of discontinuities, then when looking at the detailed behavior of single rock blocks and joints, a more anisotropic behavior must be considered, as the mechanical properties will vary in different directions.

\subsubsection{Rock Mass Classification and Properties}

The Grängesberg Pilot Plant is located in an area dominated by a medium-grained granitic rock (for intact rock: $\sigma_{\mathrm{c}}=340 \mathrm{MPa}, E=56 \mathrm{GPa}$ ). Steep joints are found in mainly three directions in the area. Horizontal joints occur only sparsely. The initial horizontal stresses are low (1-4 MPa). During the investigation phase, geological information was gathered from the following activities:

- Field observations relating to joint spacing and orientation, joint roughness, joint filling materials, and groundwater flow.

- In situ stress measurements to determine the principal stresses of the rock mass. 
- Core drilling to determine the Rock Quality Designation (RQD).

- Laboratory tests on core samples for determining uniaxial compressive strength, elastic modulus, density, and Poisson's ratio of the intact rock.

The geological information gathered above was used to classify the rock mass according to two different methods: the geomechanics Rock Mass Rating (RMR) system and the Q (Tunneling Quality Index) method. Both of these methods are standard methods in Sweden, are internationally recognized, and have been used for the design of underground excavations all over the world.

The RMR system [Bieniawski, 1973] uses six parameters to classify a rock mass:

1. Uniaxial compressive strength of the intact rock

2. RQD

3. Spacing of discontinuities

4. Condition of discontinuities

5. Groundwater conditions

6. Orientation of discontinuities.

The $\mathrm{Q}$ method [Barton et al., 1974] is based on a large number of case histories. The rating is based on the following six parameters:

- RQD

- Joint set number, $\mathrm{J}_{\mathrm{n}}$

- Joint roughness number, $\mathrm{J}_{\mathrm{r}}$

- Joint alteration number, $\mathrm{J}_{\mathrm{a}}$

- Joint water reduction factor, $\mathrm{J}_{\mathrm{w}}$

- Stress reduction factor, SRF.

In order to estimate the mechanical properties; i.e., the compressive strength (characterized with cohesion, $c$, and the angle of internal friction, $\phi)$ and the $E$ modulus of the rock mass in Grängesberg, several empirical methods were used. The methods are based on or related to the rock mass classification. Methods used in Grängesberg are listed in Table 5-1.

As a result of the site investigation, the rock mass classification and the estimation of the mechanical properties, the values for the important parameters shown in Table 5-2 were obtained. 
Table 5-1. Methods Used in Grängesberg Pilot Plant to Estimate the Mechanical Properties of the Rock Mass

\begin{tabular}{|c|c|c|}
\hline Parameter & Methods & Methods Based on \\
\hline $\begin{array}{l}\text { Compressive strength of } \\
\text { rock mass }(c, \phi)\end{array}$ & $\begin{array}{l}\text { Hoek and Brown [1980] } \\
\text { Bieniawski [1978] } \\
\text { Stille et al. [1982] }\end{array}$ & $\begin{array}{l}\text { RMR value } \\
\text { RMR value } \\
\text { RMS value (modified RMR) }\end{array}$ \\
\hline$E$ modulus of rock mass & $\begin{array}{l}\text { Bieniawski [1978] } \\
\text { Stille et al. [1982] } \\
\text { Serafim and Pereira [1983] } \\
\text { Grimstad and Barton [1993] }\end{array}$ & $\begin{array}{l}\text { RMR value } \\
\text { RMR value } \\
\text { RMR value } \\
\text { Q value }\end{array}$ \\
\hline
\end{tabular}

Table 5-2. Parameters Used to Describe the Grängesberg Pilot Plant Site

\begin{tabular}{||l|l|l||}
\hline \multicolumn{1}{|c|}{ Parameter } & \multicolumn{1}{|c||}{ Estimation Based on } & \multicolumn{1}{|c||}{$\begin{array}{c}\text { Estimated } \\
\text { Value }\end{array}$} \\
\hline \hline$E$ modulus (rock mass) & Methods indicated in Table $5-1$ & $30 \mathrm{GPa}$ \\
\hline $\begin{array}{l}\text { Uniaxial compressive strength (rock } \\
\text { mass), } \sigma_{c, m}\end{array}$ & Methods indicated in Table $5-1$ & $9 \mathrm{MPa}$ \\
\hline Dilatancy, $\psi$ & Conservative assumption & $10^{\circ}$ \\
\hline Angle of internal friction, $\phi$ & Methods indicated in Table $5-1$ & $35^{\circ}$ \\
\hline Cohesion, $c$ & Methods indicated in Table $5-1$ & $2.3 \mathrm{MPa}$ \\
\hline Tensile strength (rock mass), $\sigma_{t, m}$ & Conservative assumption & $0 \mathrm{MPa}$ \\
\hline Poisson's ratio, $v$ & Reasonable assumption & 0.1 \\
\hline Density, $\delta$ & Lab test on core samples & $2700 \mathrm{~kg} / \mathrm{m}{ }^{3}$ \\
\hline Largest horizontal stress, $\sigma_{H}$ & In situ stress measurements & $2.5 \mathrm{MPa}$ \\
\hline Smallest horizontal stress, $\sigma_{h}$ & In situ stress measurements & $1.3 \mathrm{MPa}$ \\
\hline Vertical stress, $\sigma_{v}$ & $\rho \times g \times h$ & $1.3 \mathrm{MPa}$ \\
\hline
\end{tabular}

\subsubsection{Predicting the Deformation for the Grängesberg Pilot Plant}

The parameter values from Table 5-2 were used for calculating the deformations with a finite element code known as JOBFEM (see Appendix A). With this code, the rock mass is modeled as an axially symmetric continuum. Calculations were made for the two different horizontal (radial) stress conditions: 1.3 and 2.5 MPa. The modeling included the excavation phase. 
The predicted total radial deformation at the cavern boundary (for either of the two horizontal in situ stress conditions) in Test Room 2 (Grängesberg Pilot Plant) due to pressurization is shown in Figure 5-4. Also shown is the expected spread in deformation of \pm 1 millimeter due to local behavior of single rock blocks and joints.

RSI-835-99-094

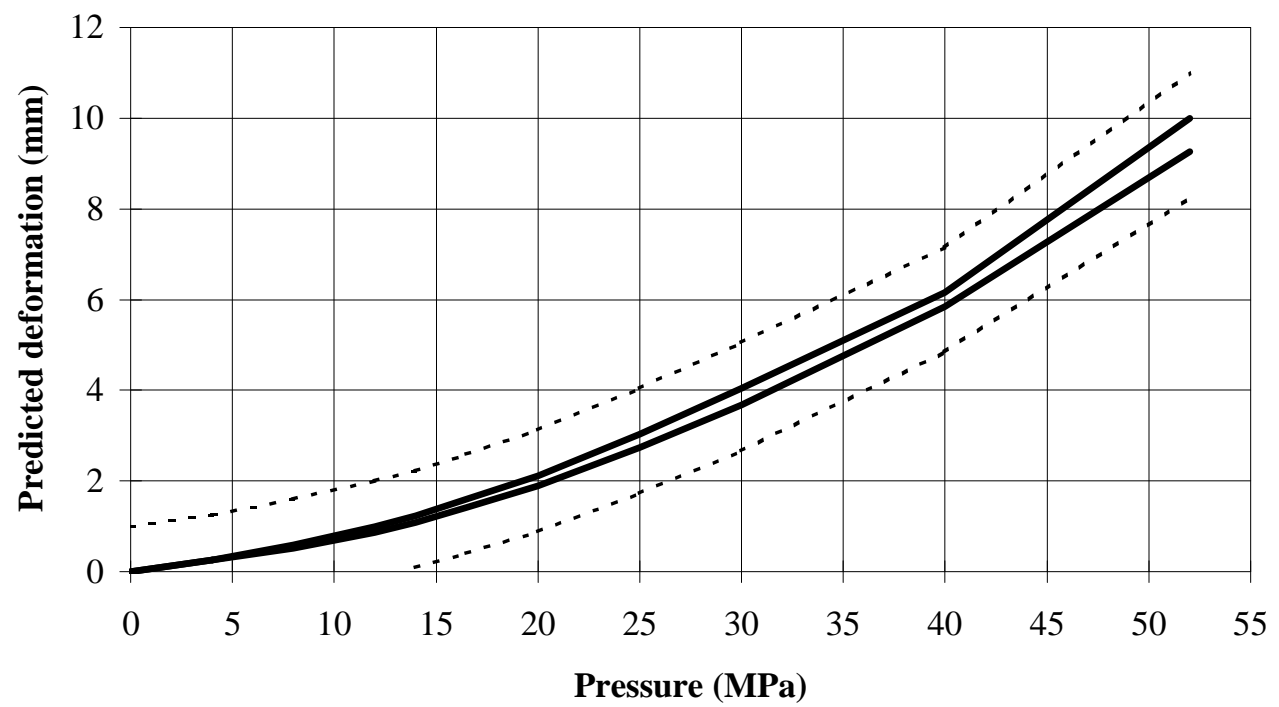

Figure 5-4. Predicted Radial Deformations in Test Room 2 (for Horizontal Stress Conditions of 1.3 and 2.5 MPa), Grängesberg Pilot Plant. Expected Spread in Deformation Is Set at \pm 1 Millimeter.

The JOBFEM calculations were also used for predicting how far out from the cavern the rock mass will be affected by the cavern pressure. The deformations were expected to be exponentially decreasing with the distance from the cavern. Figure 5-5 shows the predicted distribution of radial deformation along a 11.5-meter-long extensometer for different pressures. The length of the extensometer is measured from the rock surface outward.

\subsubsection{Measured Deformations in Grängesberg Pilot Plant}

The total radial deformations measured in all three test rooms in Grängesberg Pilot Plant for different cavern pressures are shown in Figure 5-6. Figure 5-7 shows the measured distribution of radial deformation along a 11.5-meter-long extensometer. The length of the extensometer is measured from the rock surface outward. 


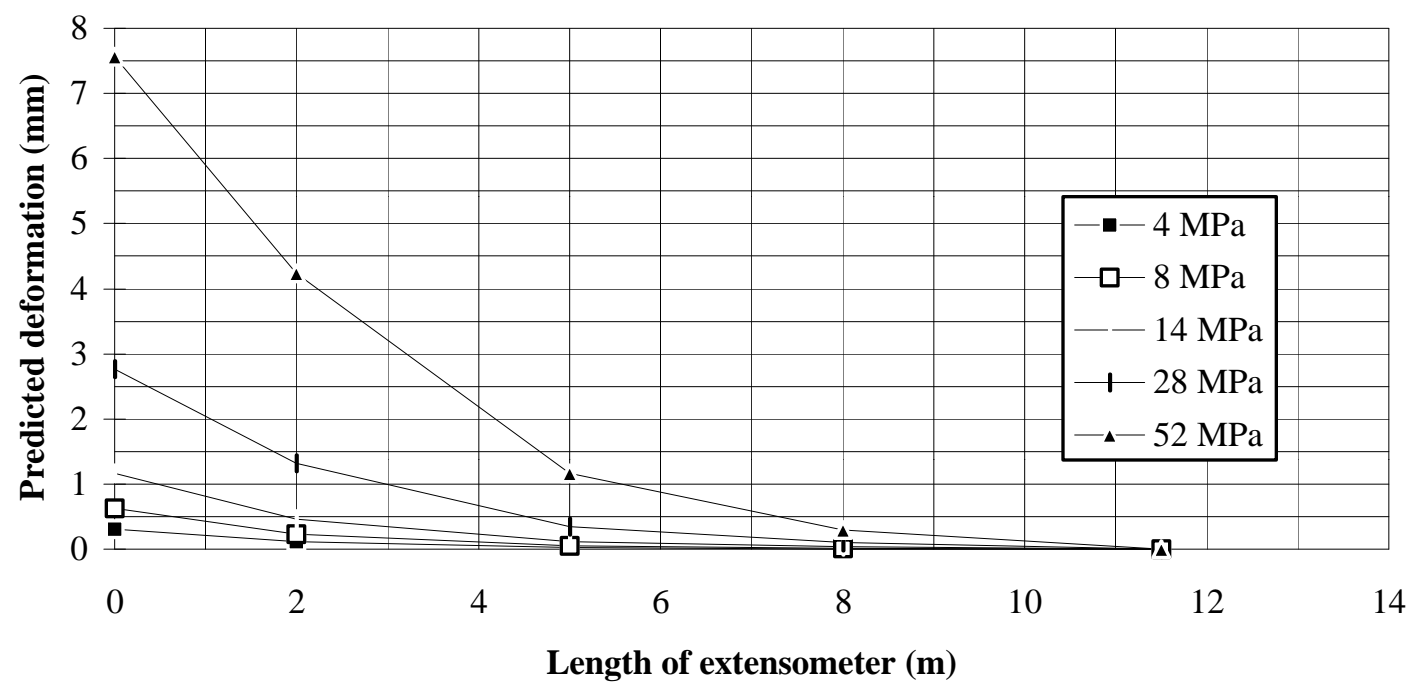

Figure 5-5. Predicted Distribution of Radial Deformation Along an 11.5-Meter-Long Extensometer.

RSI-835-99-096

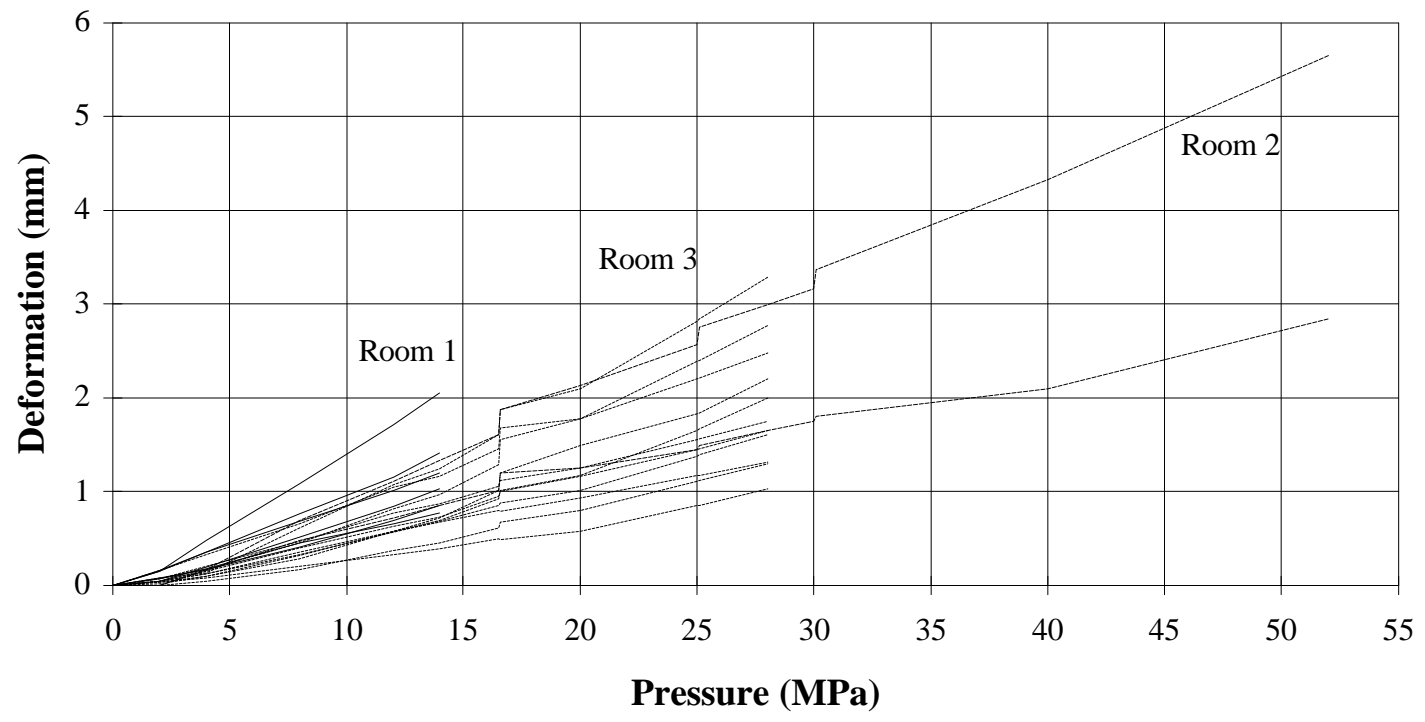

Figure 5-6. Total Radial Deformations Measured in all Three Test Rooms (Grängesberg Pilot Plant). 


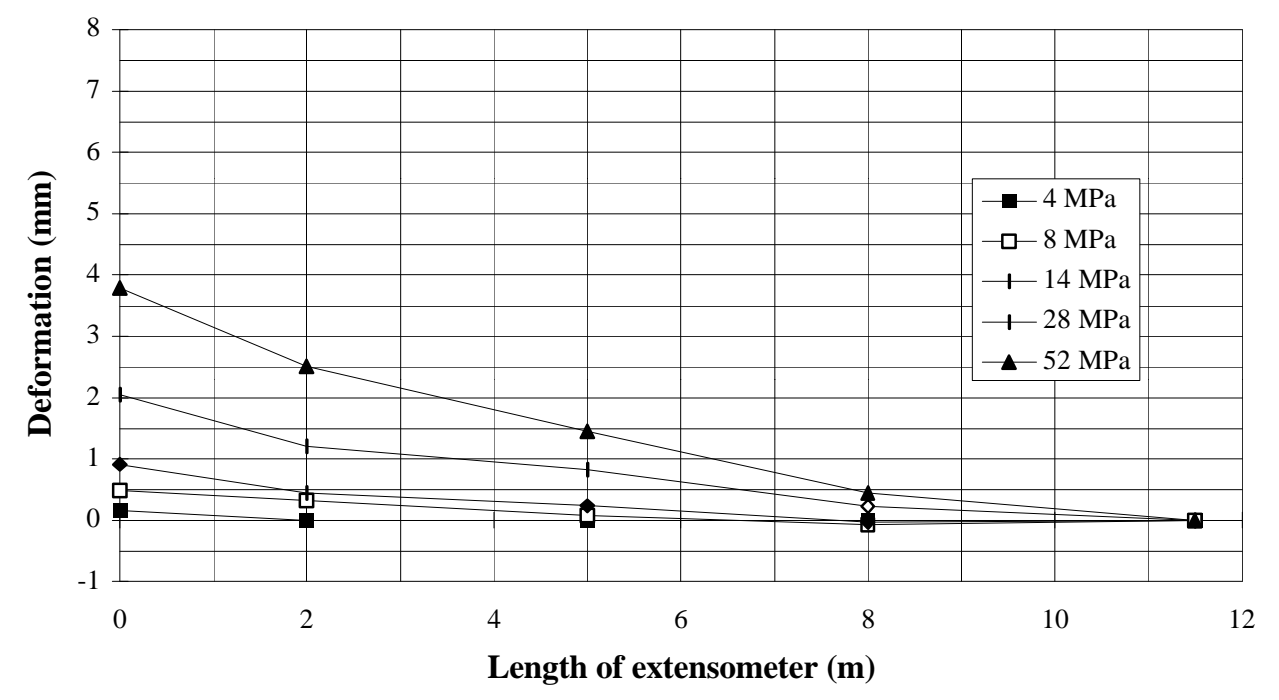

Figure 5-7. Measured Distribution of Radial Deformation Along an 11.5-Meter-Long Extensometer.

\subsubsection{Comparison Between Predicted and Measured Behavior}

Figure 5-8 shows the predicted radial deformations (for either of the two horizontal stress conditions) along with the measured deformations in all installed horizontal extensometers (a combination of Figures 5-4 and 5-6). The predicted deformation span and the measured deformations show good agreement for the intended maximum storage pressure range; i.e., 20$25 \mathrm{MPa}$. No measured deformation has exceeded the upper limit of the predicted span.

At high-pressure levels, the measured deformations are considerably smaller than the predicted deformations. The explanation to this is to be found both in a built-in conservatism in the methods used for estimating the mechanical properties and in the conservative approach adopted by design engineers with little previous experience in the field of high-pressure storage in an LRC.

The evaluation of the distribution of deformation along the length of all the installed extensometers shows that approximately 90 percent of the radial deformation at $28 \mathrm{MPa}$ takes place within a distance of two diameters from the cavern wall (see the example in Figure 5-7).

The analysis of the results has shown that the $E$ modulus generally was underestimated at the initial prediction. The results at $52 \mathrm{MPa}$ also indicate that the $E$ modulus is different in different directions (the deformations were measured in two perpendicular directions). The main reason for the large discrepancy at high pressures, however, has to do with the underestimation of the rock mass strength in the finite element model. 


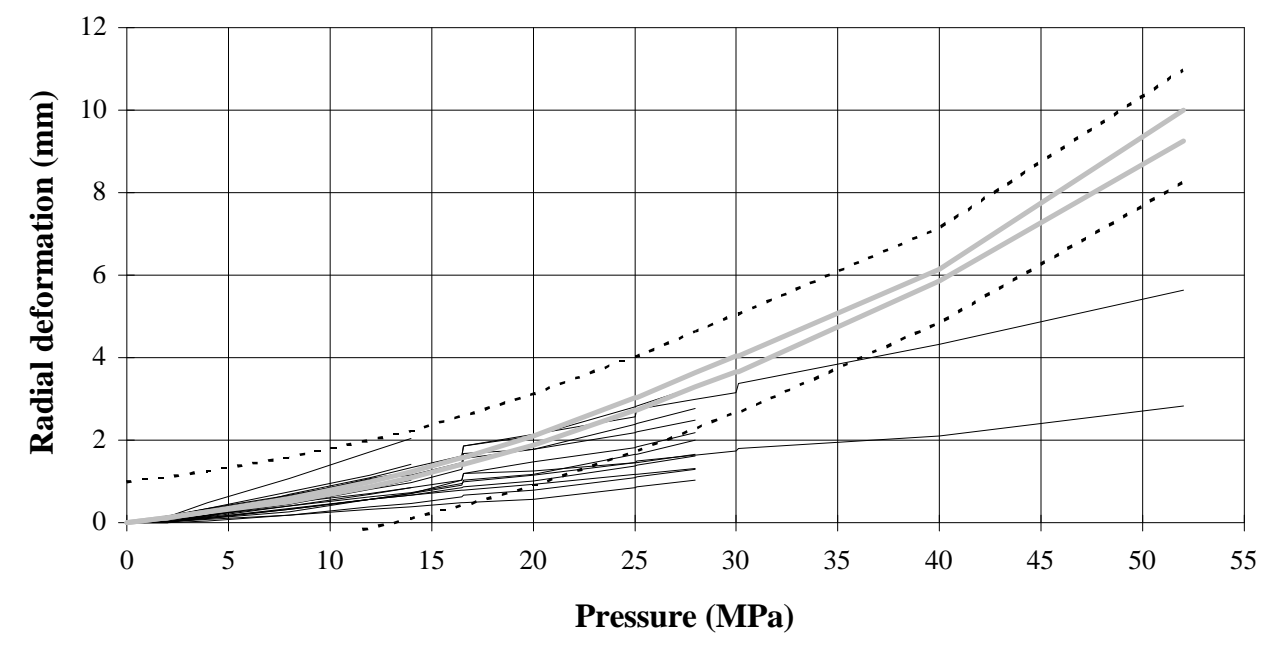

Figure 5-8. Deformations in all Horizontal Extensometers in the Three Test Caverns Along With the Predicted Deformations According to JOBFEM (Two Thick Lines for Two Different Horizontal Stress Conditions). The Expected Spread Was Set at \pm 1 Millimeter.

\subsubsection{Behavior During Multiple Cycles}

Knowledge about the long-term behavior is essential when designing peak-shaving facilities; i.e., storage caverns subjected to a very large number of cyclic loads. Several hundreds of cyclic loads to high-pressure levels have been performed in the Grängesberg Pilot Plant test rooms to evaluate the impact of the long-term deformations. Figure 5-9 shows the measured change in height (K7) and diameter (K8, K9) in Test Room 2 during 50 pressure cycles between 15 and $30 \mathrm{MPa}$. The duration of each cycle was 1 to 1.5 hours.

The general conclusion from the cyclical tests is that no significantly escalating deformations have occurred. On the contrary, a hardening behavior has been recorded; see Figure 5-10 showing the additional rock deformation in Test Room 2 during 100 pressure cycles between 1 and $16.5 \mathrm{MPa}$. This is explained by the fact that the rock mass closest to the cavern is probably compacted as rock joints are closed and sheared.

The main part of the additional deformation arises during the first 50 cycles. The total increase in the radial deformation from the 100 cycles is only about 17 percent. Pressure cycle tests performed in Test Room 3 show the same behavior. The increase in deformation due to pressure cycles is thus very limited and diminishing with the number of cycles for this case. This conclusion is assumed to be valid also for a peak-shaving facility subjected to ten complete pressure cycles a year (500 cycles over a lifetime of 50 years). 


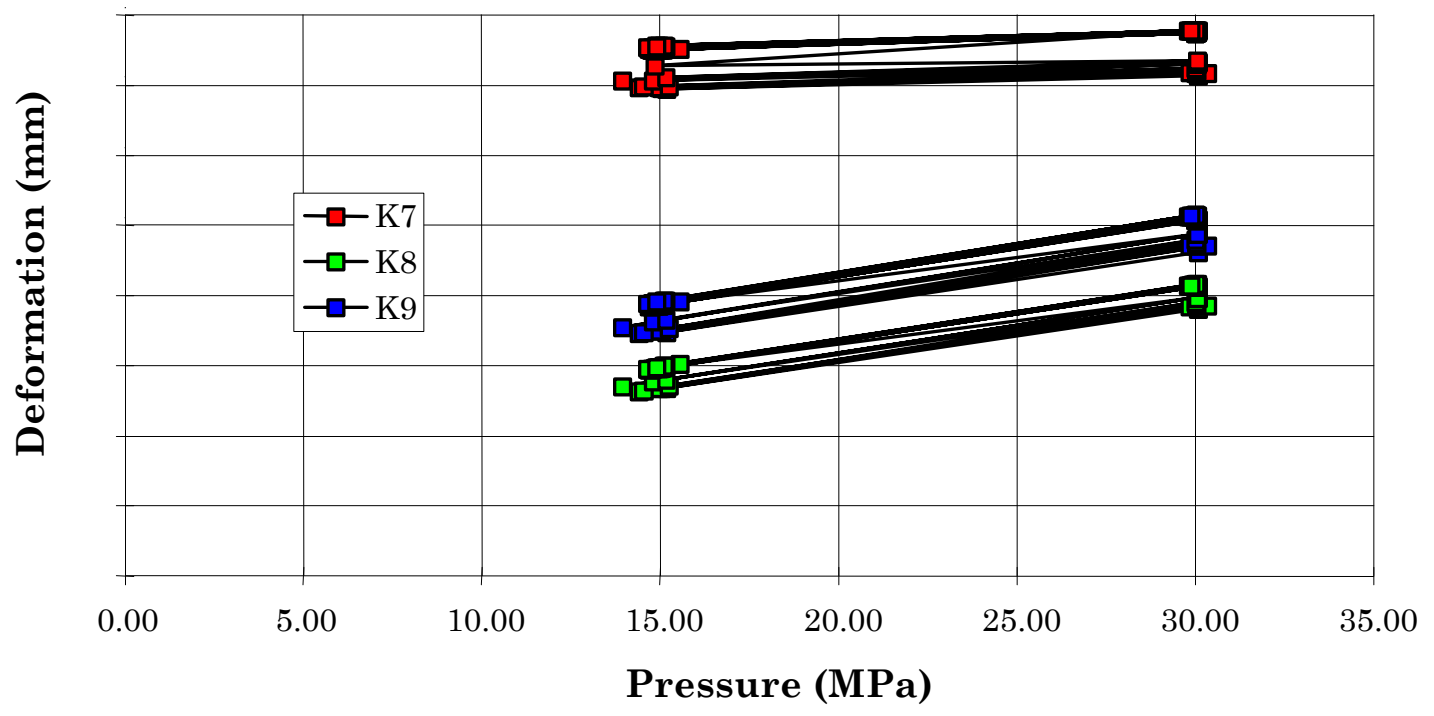

Figure 5-9. Measured Change in Diameter (K7, K8) and Height (K9) of Test Room 2 During 50 Cyclic Pressure Loads Between 15 and $30 \mathrm{MPa}$.

RSI-835-99-100

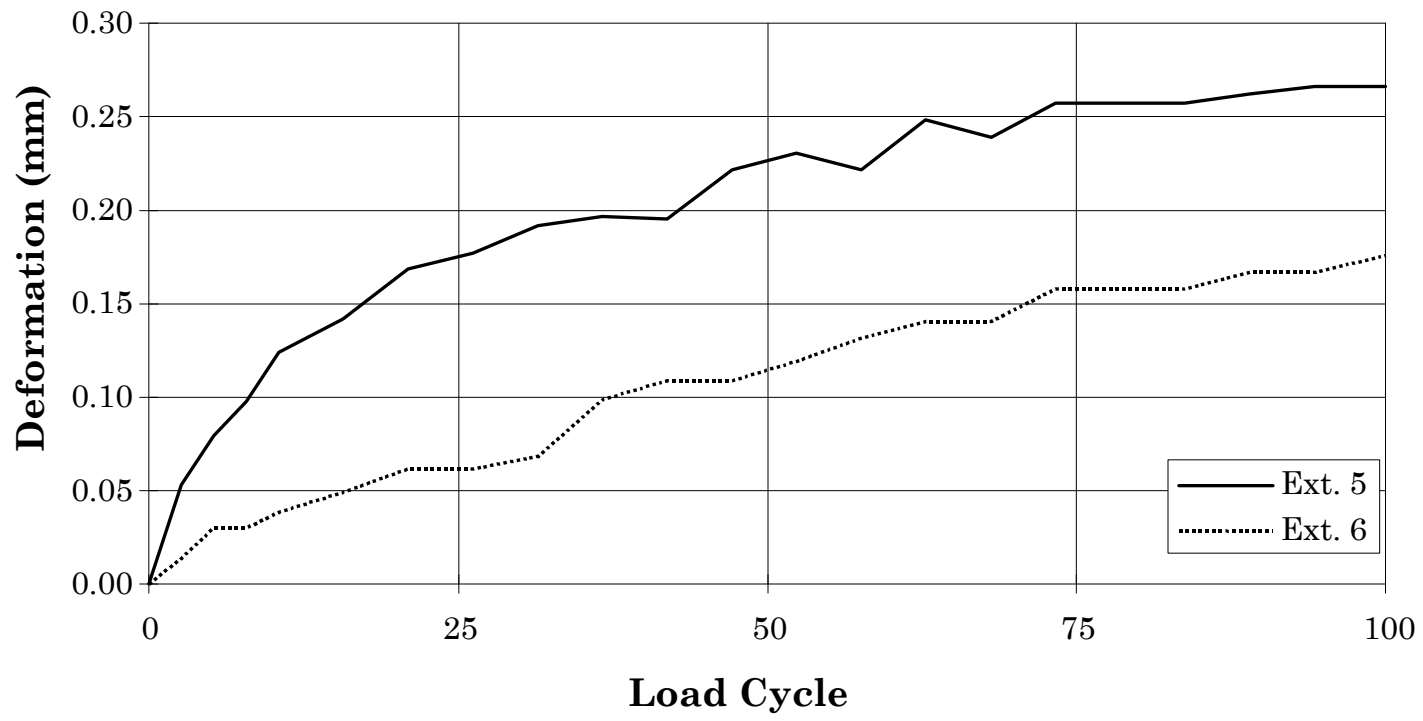

Figure 5-10. Additional Rock Deformation Registered in Test Room 2 During 100 Pressure Cycles Between 1 and 16.5 MPa. 


\subsubsection{Summary}

The general behavior of the rock mass in the Grängesberg Pilot Plant follows the expected rock mechanics behavior. The predictions made for the Grängesberg Pilot Plant regarding deformations (made with the best knowledge available at that time) have proven to be very conservative. Evaluation of the Grängesberg test results have helped to improve the empirical relationship used to estimate the mechanical properties of the rock mass and will enable design engineers to obtain better estimates; thus, optimizing the storage design. The tests in the Grängesberg Pilot Plant are probably the largest in situ tests of this type in the world for hard rock caverns and will contribute to the improvement of the methods used for estimating rock mass strength.

\subsubsection{Safety Against Uplift}

\subsubsection{Theoretical Background}

As there is limited experience regarding the safety against uplift for shallow, high-pressure rock caverns, the problem has to be approached with numerical models in combination with mechanical analogies. The prediction for the Grängesberg Pilot Plant was established with the aid of both analytical and numerical calculations combined with assumptions based on experiences from other analog applications.

The first approach uses the analogy of the resistance against uplift for flat, cylindrical anchor-plates placed in a material characterized with a cohesion of $c$ and an angle of internal friction of $\phi$ (see Figure 5-11). This has been studied both theoretically [Vesic, 1971] and experimentally [Harvey and Burley, 1973]. To calculate the resistance against uplift $\left(\mathrm{P}_{\mathrm{u}}\right)$, the following parameters were used:

- $\operatorname{cohesion}(c)$

- angle of internal friction $(\phi)$

- density of material $(\gamma)$

- depth beneath the surface $(H)$ (corresponds to rock cover for LRC)

- diameter of the anchor plate $(D)$ (corresponds to cavern diameter for LRC).

The second approach uses the method of calculating the weight of a rock overburden shaped like a cone (see Figure 5-12). The weight of the cone, and thereby also the resistance, depends on the angle $\alpha$. The shear strength of the rock mass is ignored. In rock mechanical applications (e.g., bolts anchored in rock), an angle of $30-45^{\circ}$ is generally used to describe the failure [Littlejohn and Bruce, 1975]. It is reasonable to assume that the angle should be in the same range for this case. Uplift failure will occur if the storage pressure exceeds the weight of the rock mass cone. The result of the calculations made with the anchor plate method and the cone 
method for the Grängesberg Pilot Plant, using angles in the range of $30-45^{\circ}$, are shown in Figure 5-13.

RSI-835-99-101

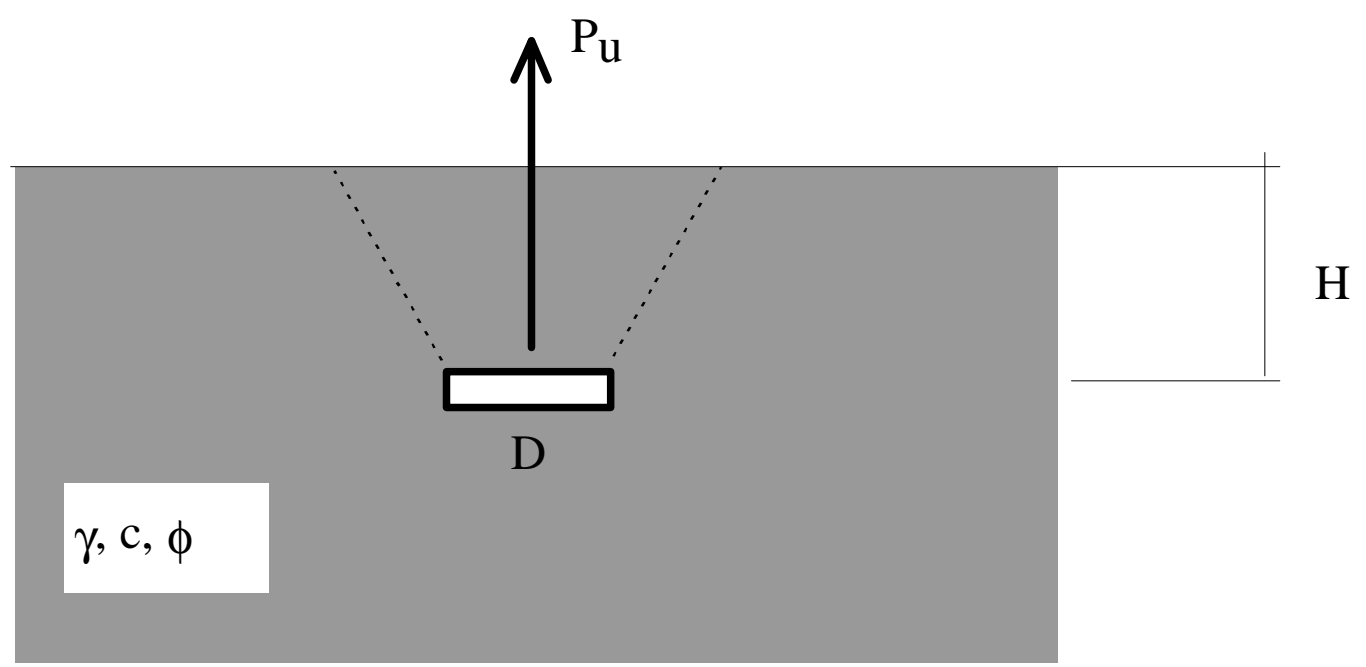

Figure 5-11. Uplift of Cylindrical Anchor Plates.

RSI-835-99-102

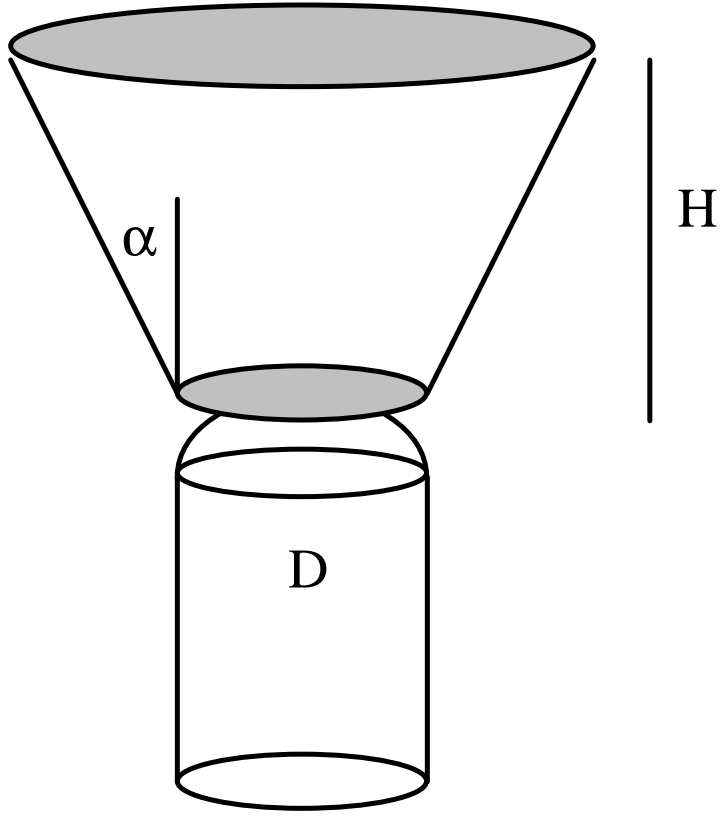

Figure 5-12. Resistance Against Uplift With a Cone-Shaped Rock Overburden. 


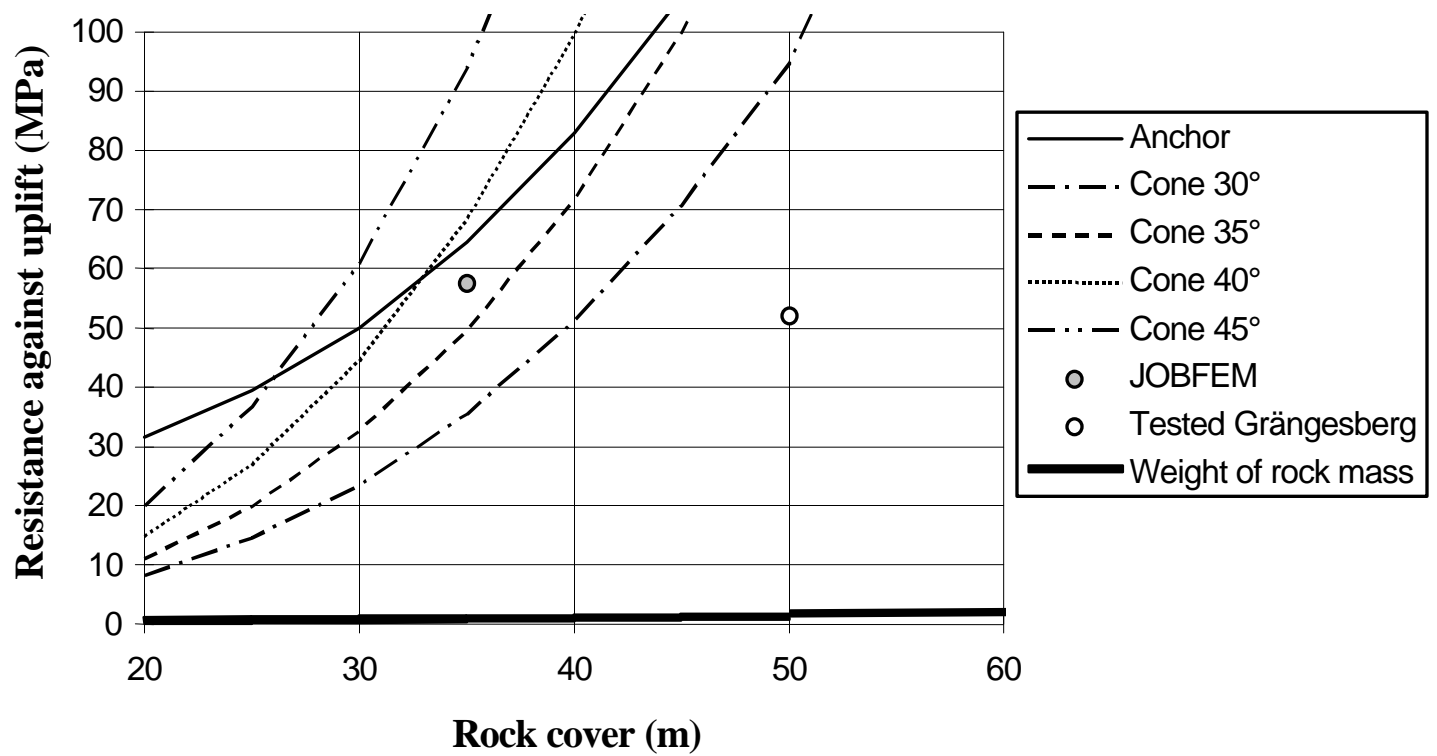

Figure 5-13. The Resistance of the Rock Mass Against Uplift Calculated With Three Different Methods for the Grängesberg Pilot Plant (Cavern Diameter 4.4 Meters and Actual Rock Cover 50 Meters).

The third method involved is a finite element modeling using the JOBFEM code. The principal input parameters for Grängesberg are those previously presented in Table 5-2. The results of the JOBFEM calculation are also shown in Figure 5-13.

\subsubsection{Study of Uplift in the Grängesberg Pilot Plant}

Figure 5-13 summarizes the calculations of safety against uplift made for the Grängesberg Pilot Plant as well as the weight of the vertical rock mass directly above the cavern.

The vertical weight of the rock mass directly above the cavern corresponds only to a pressure of 1.3 MPa. The JOBFEM calculation was made for a rock cover of 35 meters $^{1}$, indicating an uplift failure at 57.5 MPa. As shown in Figure 5-13, the uplift resistance calculated with the anchor analogy, the cone theory (with $\alpha=35-40^{\circ}$ ), and the JOBFEM code are approximately equal at a rock cover of 35 meters. This indicates a resistance against uplift in the range of 50-70 MPa.

Test Room 2, located with a rock cover of 50 meters, was successfully pressurized to $52 \mathrm{MPa}$ without any observed tendency for uplift. As indicated in Figure 5-13, this point is far below

1 The JOBFEM calculations were carried out before the final location of the storage rooms was finalized. Due to local geologic reasons, the final location selected has a rock cover of 50 meters. 
the estimated resistance against uplift. Extrapolating along the calculated results in Figure 5-13 to the actual rock cover of 50 meters, the resistance against uplift for the Grängesberg case would be expected to be approximately $135 \mathrm{MPa}$.

\subsubsection{Design Loop}

The LRC concept is characterized by a high degree of flexibility with respect to siting. The concept has been primarily developed and demonstrated to function well in Swedish bedrock of normal quality (Grängesberg). However, locations within geological formations of considerably lower quality are possible. The minimum requirements on rock mass quality are connected with the requirement to excavate and to maintain a large-scale rock cavern (diameter of 2040 meters). If this basic requirement is fulfilled, an LRC storage may be constructed. However, to make the storage economically feasible, the storage pressure must, of course, be relatively high. The maximum storage pressure is dictated by the chosen lining material and the actual geological conditions. The deformations must not exceed the maximum strain capacity of the lining material. This leads to a design loop where the design parameters are optimized in relation to each other within the frame of the geological conditions (see Figure 5-14).

RSI-835-99-104

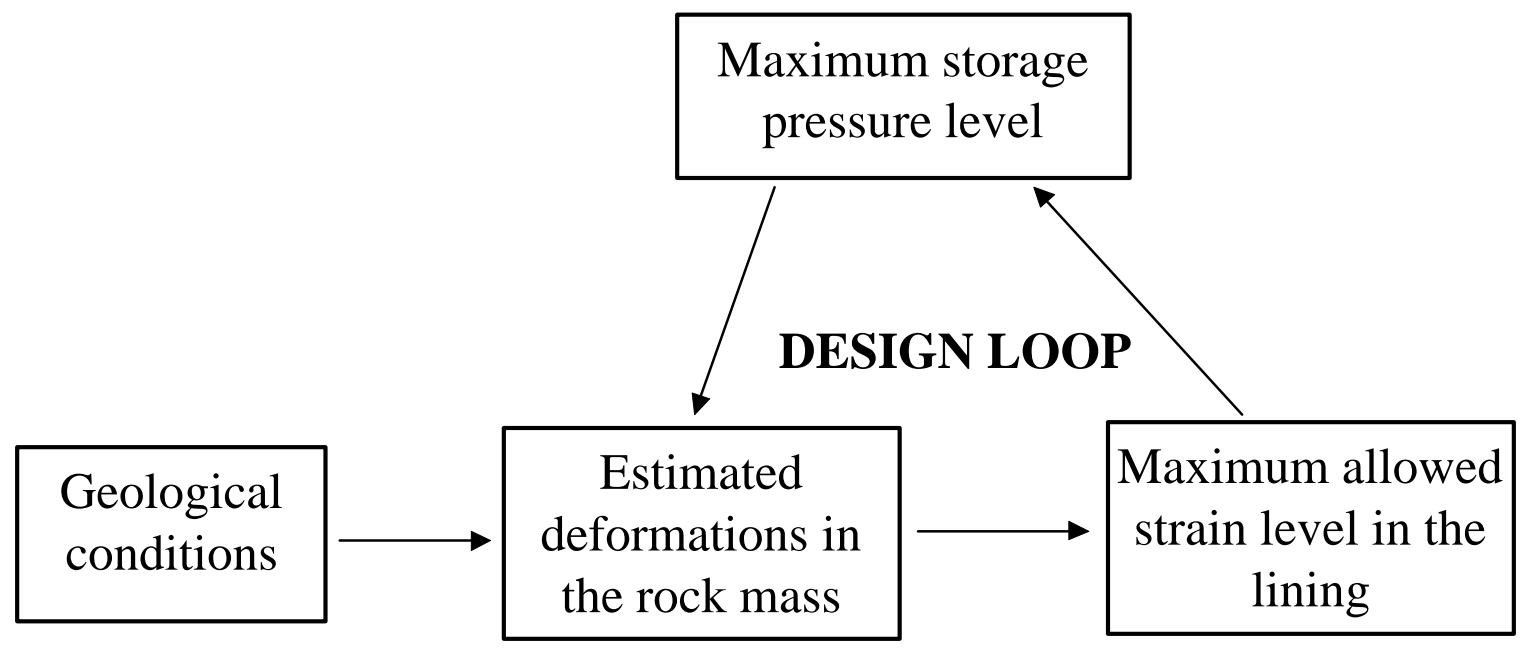

Figure 5-14. Design Loop for Technical and Economical Optimization of a Lined Rock Cavern for Storage of Gas.

With the knowledge of rock quality, the degree of homogeneity, and the initial state of stress, the same rock mechanical approach used for the Grängesberg Pilot Plant can be used for any other location to estimate the deformation caused by high gas storage pressures. A maximum allowable cavern pressure can then be determined, depending on the cavern size and the lining material according to the previously described design loop. When the maximum cavern pressure has been determined, the minimum required rock cover can also be determined. 
Screening criteria for siting LRC storage have been developed as a result of the evaluation of the Grängesberg Pilot Plant. The only geological input-data needed are the rock mass rating according to the RMR or the $\mathrm{Q}$ methods. As the rock mass rating often is well known from other underground excavations in many candidate areas, a first estimate of the suitability of the intended location may normally be possible without any significant site investigations.

Application of the RMR method for establishing cavern storage pressures is illustrated in Figure 5-15. With a knowledge of the RMR value, the storage pressure can be determined from the graph in Figure 5-15. For example, with an RMR value of 70, a storage pressure in the range up to $34 \mathrm{MPa}$ can be expected to be acceptable.

RSI-835-99-105

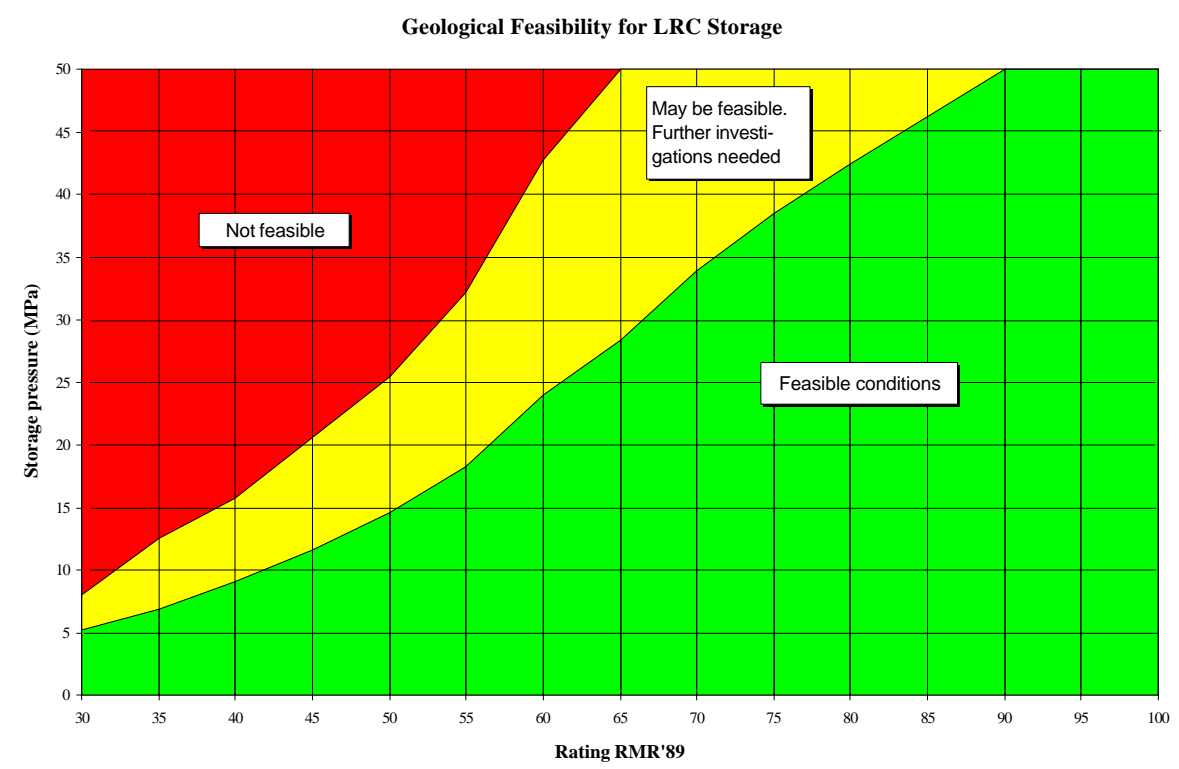

Figure 5-15. Method for Judging the Potential of a Site for LRC Storage.

If a site is judged to have potential for LRC storage, the suitability has, of course, to be further analyzed in order to make a final decision. The key to an accurate evaluation of rock mass behavior and LRC suitability is the mechanical properties estimation. This is done by using the empirical relations described in Section 5.1.2.2.

To determine the values of the relevant parameters needed for establishing a suitable predictive model, a range of field test methods and laboratory tests must be executed.

\subsubsection{Cavern Wall Principles}

The LRC concept is based on the interaction of four elements, as shown in Figure 5-16: 
1. steel liner

2. concrete layer

3. surrounding rock

4. drainage system.

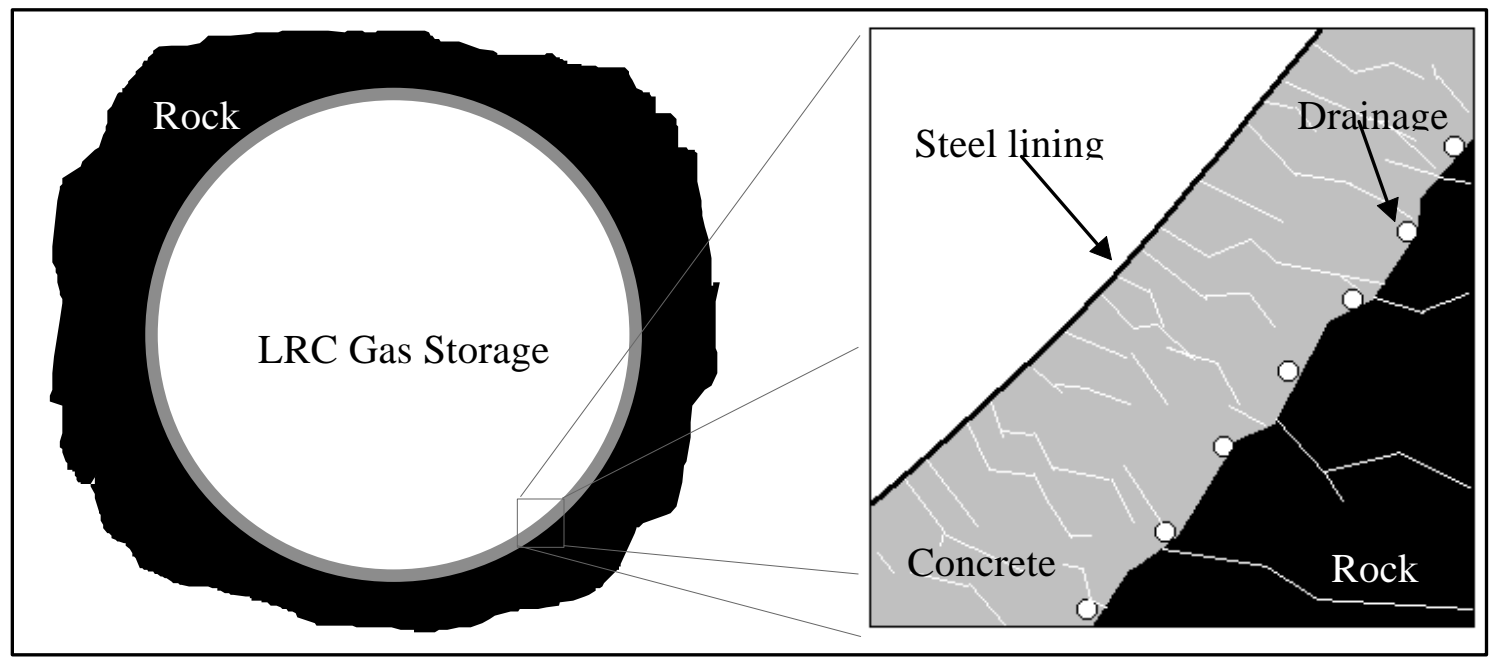

Figure 5-16. Horizontal Projection of Storage Showing the Sandwich Wall.

The steel liner will be made of carbon steel. The test in the Grängesberg Pilot Plant has shown that this is the most successful of the materials tested. The role of the steel liner is to achieve gas tightness. It is able to bridge minor cracks in the concrete.

The concrete layer is an intermediate layer and is located between the steel liner and the rock. Its main purpose is to transmit the gas pressure in the cavern to the rock and to distribute it uniformly across cracks. At the same time, it will serve as a smooth base for the steel liner.

The surrounding rock mass will support the gas pressure load on the wall, thus acting as a pressure absorber.

The drainage system consists of perforated drainpipes fixed at an oblique angle to cross horizontal and vertical cracks in the concrete and the rock. The drainage system allows the water pressure against the steel liner to be lowered when the gas pressure in the cavern is low, thus avoiding the risk of liner buckling. 


\subsubsection{Thermodynamic Behavior}

The temperature response of gas in LRC storage is a bit different than for other storage concepts. The main reason is the depth, and thus, the surrounding rock temperature. An LRC cavern will be located at approximately 150 meters (500 feet) below ground. At this depth, the temperature of the rock will be about $17^{\circ} \mathrm{C}\left(62^{\circ} \mathrm{F}\right)$. This is a great difference compared to domal salt caverns that are located at a depth of 1,000-1,500 meters (3,300-4,900 feet) where the temperature of the surrounding rock may be $50-60^{\circ} \mathrm{C}\left(120-140^{\circ} \mathrm{F}\right)$.

A sample calculation of the temperature of gas in storage is shown in Appendix B. During the rapid withdrawals (anticipated for LRC to be 10 days or less), the gas temperature will go below $0^{\circ} \mathrm{C}\left(32^{\circ} \mathrm{F}\right)$. The worst case is a withdrawal after a quiescent period in the storage in which the temperature will have gone down by cooling from the ambient rock temperature. After a 3-month quiescent period, the temperature after withdrawal will go down to $-18^{\circ} \mathrm{C}$ $\left(0^{\circ} \mathrm{F}\right)$.

The transient temperature distribution can have a negative impact on the steel liner and the concrete. A low temperature at the end of the withdrawal results in an increase in the residual gas volume in the cavern, thus increasing the base gas requirement and can also cause gas hydrate formation to occur. If repeated freezing and thawing occurs, it could have a negative impact on the concrete outside the steel liner. After many years of operation, the concrete might degrade.

Depending on the water content of the gas, hydrates may form toward the end of the gas withdrawal cycle. During gas injection, the reaction is, of course, the opposite. Gas will be cooled after the compressor, but the compression inside the cavern will develop heat that will increase the temperature inside the cavern, and thus, limit the working gas volume in the cavern. At the end of a 20-day injection, the cavern temperature is approximately $43^{\circ} \mathrm{C}\left(108^{\circ} \mathrm{F}\right)$ (see Appendix B).

In order to increase the working gas volume and avoid the risks associated with low temperature described above, a circulation system was created. With the circulation system, gas inside the cavern will be cooled during injection and heated during withdrawal. The temperature after injection will be equal to the ambient rock temperature, $17^{\circ} \mathrm{C}\left(62^{\circ} \mathrm{F}\right)$, and the temperature after withdrawal will be a minimum of $0^{\circ} \mathrm{C}\left(32^{\circ} \mathrm{F}\right)$. The working gas will increase approximately 30 percent with the circulation system compared to an unheated/uncooled LRC storage system. The circulation system is further described in Section 5.2.6.

\subsection{CONCEPTUAL DESIGN}

The storage consists of four rock caverns located at a depth of approximately 150 meters (500 feet). Caverns are excavated through an access tunnel. Each cavern will have a separate 
shaft for connection to the aboveground facilities. Drawing No. EXGAZ-16 (see Appendix C) shows the cavern and access tunnel configuration.

\subsubsection{Storage Performance}

The storage will have the following characteristics:

$\begin{array}{lll}\text { Number of caverns } & 4 & \\ \text { Geometric volume } & 320,000(11.3 \mathrm{MMcf}) & \mathrm{m}^{3} \\ \text { Working gas } & 74 \times 10^{6}(2.6 \mathrm{Bscf}) & \mathrm{m}^{3} \\ \text { Gas withdrawal, maximum } & 7.4 \times 10^{6}(260 \mathrm{MMscf} / \mathrm{d}) & \mathrm{m}^{3 / \mathrm{d}} \\ \text { Gas injection } & 3.7 \times 10^{6}(130 \mathrm{MMscf} / \mathrm{d}) & \mathrm{m}^{3 / \mathrm{d}} \\ \text { Gas circulation, maximum } & 7.4 \times 10^{6}(260 \mathrm{MMscf} / \mathrm{d}) & \mathrm{m}^{3 / \mathrm{d}} \\ \text { Cycles } & \text { Several } & \\ \text { Duration of withdrawal } & 10 & \mathrm{day} \\ \text { Duration of injection } & 20 & \mathrm{day} \\ \text { Pipeline pressure } & 84(1,220 \mathrm{psi}) & \mathrm{bar} \\ \text { Maximum storage pressure } & 230(3,330 \mathrm{psi}) & \mathrm{bar} \\ \text { Minimum storage pressure } & 38(550 \mathrm{psi}) & \mathrm{bar} \\ \text { Storage temperature after injection } & 20\left(68^{\circ} \mathrm{F}\right) & { }^{\circ} \mathrm{C} \\ \text { Inlet gas temperature } & 10\left(50^{\circ} \mathrm{F}\right) & { }^{\circ} \mathrm{C} \\ \text { Minimum storage temperature } & 0\left(32^{\circ} \mathrm{F}\right) & { }^{\circ} \mathrm{C} \\ \left.\text { Compressibility (@ p }=230 \text { bar, T }=20^{\circ} \mathrm{C}\right) & 0.82 & \\ \left.\text { Compressibility (@ p = 38 bar, T }=0^{\circ} \mathrm{C}\right) & 0.90 & \\ \text { Compressor injection power } & 8.8(12,000 \mathrm{hp}) & \mathrm{MW} \\ \text { Compressor circulation power } & 0.625(850 \mathrm{hp}) & \mathrm{MW} \\ \text { Refrigeration compressor power } & 1.9(2,600 \mathrm{hp}) & \mathrm{MW} \\ \text { Connection pipe diameter } & \mathrm{DN} 400\left(16^{\prime \prime}\right) & \\ \text { Shaft pipes, inlet } & \mathrm{DN} 250\left(10^{\prime \prime}\right) & \\ \quad \text { outlet } & \mathrm{DN} 300\left(12^{\prime \prime}\right) & \\ & & \\ & & \end{array}$

The performance corresponds to a cavern storage design with 10-day withdrawal and 20-day injection.

\subsubsection{Site Description}

The LRC is a challenge from both a design and construction perspective due to the scale of the rock caverns. A cavern is a 95-meter-high (312-foot-high) standing cylinder with a diameter of approximately 37 meters (121 feet).

The minimum depth of the caverns is estimated as approximately 150 meters (500 feet). The final decision will be made based on: 
1. The local geology, which means that the vertical placement of the caverns will be made to avoid geological weak zones in the roof section of the caverns.

2. Rock mechanical properties. Minor geological weakness zones might be present in the wall sections, but larger weakness zones should be avoided.

The local topography will be used in such a way that the access tunnel length will be minimized. It is not unrealistic to assume that a difference in height of about 50-70 meters (160-230 feet) or more will be present at any site chosen. This will shorten the access tunnel and/or minimize the declination of the tunnel.

The aboveground facilities need to be considered when planning the needed space in the site selection process. This includes space not only for the machinery and pipe installations, but also the space needed for excavated rock and waste water treatment.

The geological environment that will be sought during the site selection process will consist of primarily crystalline rock; e.g., granite and granodiorite. The rock mechanical properties of this rock will be classified according to the RMR system [Hoek et al., 1997]. The major part of the rock mass investigated should have an RMR value of 60 and above. Most likely, the average RMR value will be around 80 .

\subsubsection{General Layout}

The general layout of the facility shows a system of four caverns, shaped as standing cylinders (see Drawing No. EXGAZ-15 and EXGAZ-16, Appendix C). Each cylinder has a diameter of approximately 37 meters (121 feet) and a height of approximately 95 meters (312 feet). Each cavern should be placed with a distance of at least 100 meters between the cavern walls to avoid interaction effects in the rock mass when pressurizing the caverns. This approach has been verified in a test facility in Sweden [Isander, 1994]. The roofs of the caverns are to be shaped as semispherical domes in order to be stable during rock excavation and steel liner construction while the bottom portions of the caverns will be more flattened but still with a somewhat rounded shape. An access tunnel from the surface will spiral down to the levels where the caverns are entered. The connection between the caverns and the surface, as far as gas transportation is concerned, will consist of separate shafts for each cavern.

\subsubsection{Rock Excavation}

The main rock engineering components of the LRC concept are the excavation of the access tunnels, the storage cavern, the shaft for the gas pipes, and the grouting and rock supporting operations. 


\subsubsection{Excavation of the Tunnel Entrance}

The tunnel entrance will be excavated using conventional drill-and-blast methods. This means that the work needs to be planned carefully to avoid inconveniences regarding vibrations, noise, dust, and air pressure waves to people, the surrounding structures, and other concerns that might be sensitive. The entrance will be planned in such a way that the amount of excavated rock will be minimized, although this is dependent on the local geology and rock mechanical features.

\subsubsection{Excavation of the Tunnels}

The excavation will be performed as conventional drill-and-blast operations, and the tunnels will be made in a horseshoe shape, although the shape might vary slightly due to local geological and rock mechanical conditions. The final shape of the tunnels should not be less than the theoretical section and the excess excavation should be limited. Controlled blasting techniques will be utilized throughout construction to minimize overbreak damage to the remaining rock mass. The drilling pattern and the charge plan will be adapted to suit the local geology and to meet the demands set out regarding the damaged zone around the tunnel as well as to minimize the overbreak of rock.

The tunnels will be excavated with a minimum of excess rock. The cross section of the tunnels at straight stretches should be around 25 square meters (270 square feet) and in curves

around 43 square meters (463 square meters). The tunneling operations will need niches along the tunnel to allow for vehicles turning. Temporary pump pits will also be made, as well as meeting places for vehicles.

Rock support will be used when needed; i.e., spot bolting. The bolting will be performed with grouted rebar. Use of temporary support might be needed; e.g., friction bolts or anchored bolts, but will not be included in the final support. Systematic bolting can occur as well as shotcrete with or without steel fibers, depending on the local geological and rock mechanical conditions.

In certain portions of the facility, systematic bolting and shotcrete can be used, such as where the tunnel splits in two or at the position of pump pits. Systematic bolting may also be needed at sections with poor Rock Mass Quality.

Grouting will be needed to minimize the amount of groundwater leaking into the tunnel, in order to optimize the pumping equipment as well as to reduce the influence on the groundwater level. Grouting operations will primarily use cement-based grout. The grout curtain will be designed to suit the local geology and might vary during the excavation of the tunneling works. The design of the grouting will include specification of the number of holes, lengths, and directions. The grouting operations will need careful monitoring as the tunneling proceeds. Change of the drilling pattern might also be necessary. 


\subsubsection{Excavation of the Shafts}

Two types of shafts will be excavated in the LRC facility. The locations and functions of the various shafts are described below. One shaft type is the shorter shaft, 15-20 meters (4966 feet) in length, which will be excavated by the drill-and-blast method. Drilling can be performed as long-hole drilling, after which blasting can be performed either as retreat blasting or in one single blast. The choice is dictated by the quality demands that are made and on the local geological and rock mechanical conditions.

Longer shafts can be made by using raise-boring techniques. Shafts with a length of more than 40 meters (131 feet) and with a diameter of less than 5 meters (16 feet) can easily be made by raise boring at competitive costs. Rock support costs will be lower using the raise-boring method, compared to conventional drill-and-blast methods. When raise boring a shaft, it is important to be able to control ingress of groundwater into the shaft. Therefore, it is advised to drill long holes at the position of the shaft where grouting can be performed.

Support might be needed in the shafts, even if raise boring is used. These supports will most likely be limited to shorter rock bolts and shotcrete, possibly fiber reinforced.

\subsubsection{Installation Chambers Above the Caverns}

Above each cavern, a small chamber will be made. It will be used for pregrouting above the cavern and pouring concrete. The chamber will be approximately $7 \times 7$ meters $(23 \times 23$ feet $)$ and some 6-7 meters (20-23 feet) high. The shaft down to the cavern has to be adapted to the concrete plug needed to seal the cavern. The distance between the cavern and the tunnel above is around 15-20 meters (49-66 feet). This dimension might change, however, due to local geological conditions. The shaft can be made by raise boring or by using the drill-and-blast method, the latter being the most efficient.

\subsubsection{Excavation of the Rock Caverns}

The excavation of the caverns can be made in different ways and the decision on what method to use will be based on the experience and capability of the different contractors (e.g., Sturk and Stille [1995]; Sagefors and Daerga [1996]).

Before the excavation work starts inside the caverns, grouting operations will take place from the small chambers above the caverns. Long drillholes will be made in a fan shape into the rock mass above the caverns. These drillholes will be grouted, using cement, to ensure that the groundwater movements in the rock mass around the caverns will be kept as small as possible during excavation. 
The access tunnels will enter the planned cavern at two or more points. From these entrance points, the excavation will proceed in a manner that will be both safe and economical. The height of the caverns makes it necessary to have the highest level of safety during the operations, and the excavation sequence will be planned in such a way that exposure to hazardous situations is minimized.

The more traditional way of excavating the caverns would be to enter the cavern at the top and to excavate the cupola. This operation puts very high demands on accuracy when drilling and blasting, as the roof is a sensitive part of the construction. From the entrance level, a spiralling ramp is made upward as the roof section is excavated. As the cupola is halfspherical, it puts special demands on the excavation technique used. Once the roof is excavated and secured with systematic bolting and shotcrete, the ramp is removed and the wall reinforced accordingly. The barrier position at the top of the cavern will be finally shaped from inside the cavern as the excavation work is being done in the cavern cupola.

The cavern would also be entered at the bottom where a level for mucking out the waste rock would be established. The shape of this level might vary, depending on what excavation sequence is chosen. One possible scenario is to excavate a small chamber at the center of the cavern at the lower entrance level. A raise-bored shaft could then be made from the upper access level. This shaft might be enlarged to a suitable diameter as it would be used as a rock pass into which the waste rock will be dumped. The rock would be loaded and hauled to surface.

The remaining rock in the cylindrical part of the cavern will be slashed into the shaft as the excavation operation proceeds downward in a spiral. The size of the blasts will depend on local geological factors, as well as on the methods used by the contractor. Reinforcement of the cavern walls will be carried out, using rockbolts and shotcrete, as the excavation proceeds. Additional grouting of the walls might be necessary to avoid wet working conditions inside the cavern and to facilitate later casting of concrete against the walls.

The last part of the rock cavern to be excavated is the bottom. The most optimal shape would be to make the same shape as the roof, which is half-spherical. The problems encountered doing that in the bottom of the cavern are so significant that a compromise has to be made, allowing the bottom to be rounded but not in a perfect half-sphere. The excavation proceeds in the same way as earlier; i.e., a spiralling ramp is used to reach the correct level.

\subsubsection{Excavation of the Barrier Positions}

The barrier or seal positions are to be blasted with extra care to create a smooth surface with as few fractures as possible. The barriers will be placed at the tunnel entrances in connection with the concrete wall inside the caverns. The barriers will be approximately 4-6 meters (1320 feet) long. The blasting procedure will include making a pilot tunnel along the length of the 
barrier, after which slashing of the walls will be made in shorter sections. At the position of the barrier, the tunnel will be made wedge shaped to increase the pressure-absorbing capability of the barrier.

The same technique will be used at the top of the cavern where the shaft will enter the cavern. The smooth blasting of the barrier position will be made from inside the cavern. This section of the shaft will also be made wedge shaped.

\subsubsection{Excavation of the Pump Pits}

Pump pits of a conventional type will be needed at one or more positions within the facility. The excavation of these pits will be made using the conventional drill-and-blast method, after which concrete casting works will take place.

At the bottom of the access tunnels at the lower parts of the caverns, a pump pit will be made. It will be made to a depth lower than the bottom of the cavern to ensure that the drainage water from the cavern will be transported to the pump pit. The connection between the pump pit and the cavern will be through one or more drillholes from the bottom of the caverns to the bottom of the pump pit.

\subsubsection{Excavated Rock Treatment}

The calculated amount of excavated rock for a four-cavern facility is approximately $400,000 \mathrm{~m}^{3}$ (14 million cubic feet). Assuming a swelling factor of 1.6 results in a total volume of $640,000 \mathrm{~m}^{3}$ (22.6 million cubic feet) of excavated rock to be deposited, sold, or used in the construction works.

The rock produced at the construction site will be of good quality and there should be several ways of using it in the construction work at the site. The rock can be used for aggregates in the concrete production and for the foundation of the surface structures. If not used on site, the produced aggregates should hold a commercial value in a favorable market, provided other construction projects are occurring in the same area. The value of the aggregates decreases very quickly with required haulage distance.

If the excavated rock is not being used for construction work, it has to be deposited on site. Even if the excavated rock is being used, a temporary deposit area needs to be established, although not of the same size as if all rock has to be deposited.

A permanent deposit area needs to be designed to accommodate the local demands. Consideration has to be taken of the surrounding landscape and vegetation as far as the visual perception of the deposit is concerned. The effects on vegetation and groundwater must also be taken into consideration as far as water treatment is concerned. Other factors, such as dust, 
noise, and visual impact on the site, must be considered. If the deposit is placed in remote areas with little or no population, the environmental effects should be limited.

\subsubsection{Treatment of Leakage Water}

A certain amount of groundwater will leak into the tunnel system of the facility. This water has to be pumped to the surface and processed before passing it on to any natural recipient. This treatment will most likely consist of sedimentation dams to allow any rock particles present in the water to settle. These sediments are being produced mainly in the drilling operations of the rock excavation. Other materials can be present in the leakage water, such as cement from the grouting and casting operations. This will be treated in the same way as described above. If any oil is present in the leakage water, an oil separator must be installed.

\subsubsection{Cavern Wall}

\subsubsection{Concrete Wall}

A concrete layer will be cast between the lining and the rock. The purpose of this concrete layer is twofold:

1. Transfer the load generated by the gas pressure in the cavern to the surrounding rock mass.

2. Provide a smooth base for the steel lining.

The concrete layer also has a role to minimize the strain in the lining. The large cracks that can be generated by the deformation result in a number of smaller cracks in the concrete, thus, limiting the local strain in the lining.

The selection of concrete quality should be made carefully. The concrete lining must be of sufficient strength to facilitate the distribution of cavern pressure to the rock walls. The proposed procedure to construct the wall after excavation is to start with the steel lining followed by the concrete wall.

The primary concerns related to the construction of the concrete casting are:

- Support for the form pressure

- Transportation and distribution of concrete

- Need for working space inside the formwork

- Coordination with the steel lining construction. 


\section{Support for the form pressure}

There will be a considerable height to the wall being casted. The pressure of the concrete needs to be balanced by some kind of support from inside the liner.

A special concern has to do with the support needed when pouring concrete under the bottom part of the steel lining. The upward lift of the concrete will be very large, and the only method for having a counterforce is to use dead weight in the form of water filling of the lining.

\section{Transportation and distribution of concrete}

The total concrete volume needed for one cavern wall is of the order of $7,000 \mathrm{~m}^{3}(245,000$ cubic yards), which results in a total of $28,000 \mathrm{~m}^{3}$ (980,000 cubic yards) for a four-cavern facility. To ensure a steady supply, a concrete mixing plant is needed on site (or in the near vicinity). The concrete will be transported by truck into the tunnels and might be pumped the last part of the way.

Other concrete works in the facility include the casting of pump pits and the barriers to the caverns. The amount of concrete for these works is small in comparison with the needs for the cavern wall lining, but are estimated at approximately $3,500 \mathrm{~m}^{3}(120,000$ cubic yards) for a fourcavern facility.

\subsubsection{Steel Lining}

The steel lining will provide the primary guarantee of gas tightness in the cavern. The lining material must be resistant to gas and the possible condensates and impurities that it may contain, as well as to the environment to which the outer surface is exposed.

From the structural standpoint, the lining is not intended nor designed to carry primary loads, as the concrete layer supports the lining, which in turn, is supported by the surrounding rock mass. The lining should, however, be able to withstand the stress and strain caused by the general elastic and plastic deformation of the cavern wall. In addition, with increasing gas pressure, fractures and cracks will open up in the rock mass. These will initiate smaller cracks in the concrete layer. The liner must then have the capacity to withstand the strain resulting from the spanning of the largest of those cracks.

The maximum operating pressure allowed for the storage depends on the lining characteristics and the geological conditions. It must be set at a value such that the induced deformation in the rock mass and the concrete layer does not result in the strain of the lining in excess of its capacity for deformation.

The quality of the steel lining is of primary importance for a successful LRC. It must, therefore, have the highest priority, and every effort must be put into creating the best possible 
conditions for the emplacement of the lining. The different steps in the steel lining construction work are:

- Transportation and placing of the steel plates

- Welding, including pretreatment of joint surfaces and posttreatment of weld surfaces

- Quality control regarding strength

- Quality control regarding gas tightness.

Each one of these work steps will constitute a separate workstation with specialized personnel and equipment. The main question for the choice of construction method is where to put these workstations and how the work should be carried out at these workstations.

Another important choice is the decision as to whether the welds are to be made with automatic or manual welding. Automatic welding (e.g., Submerged Arc Welding (SAW)) is expected to give a higher production rate and a uniform and high weld quality, and is, therefore, preferred. There will probably, however, always remain some welds that are not suitable to automate.

\subsubsection{Drainage System}

The hydrostatic pressure outside of the cavern due to the column of groundwater can be 1.5-2.5 MPa (220-360 psi). The drainage system is a part of the general groundwater management plan. This plan consists of three major parts:

1. During construction of the cavern, the rock mass is grouted in the cavern roof and wall in order to minimize groundwater inflow to the cavern. This is needed both for construction and operation purposes.

2. During concrete placement for the cavern wall, water influx is prevented by the drainage system.

3. During operation, when gas pressure within the cavern is lower than the hydrostatic pressure outside the cavern, or when the cavern is depressurized to atmospheric pressure for inspection and/or maintenance, the lining can then be exposed to a load from the outside. This is prevented by lowering the pressure through the drainage system.

During construction, the drainage system is in operation, draining all groundwater so as to not damage the steel lining. When the construction is completed, the drainage system is closed, and full groundwater pressure is allowed (1.5-2.5 MPa). The groundwater pressure must never be allowed to be higher than the storage pressure inside the cavern. 
The movements of the groundwater are to be minimized during operation of the LRC. This restriction is intended to reduce the risk for chemical and bacterial obstruction in the system, as well as to avoid lowering of the groundwater table.

\subsubsection{Storage Operation}

A flow diagram for the aboveground facilities is shown in Drawing No. EXGAZ-01 (see Appendix C). The operating principles for the aboveground facilities are described below. The different operational cases for the aboveground facilities are shown in Drawing No. EXGAZ-02 to 06 (see Appendix C).

\subsubsection{Injection With Flow Control}

Drawing No. EXGAZ-02 (see Appendix C) illustrates injection with flow control. When the pipeline pressure is above the cavern pressure, gas will be injected with flow control. The gas flow is measured during injection in an ultrasonic flow meter before the flow control valve. The inlet gas is analyzed in a gas chromatograph and a dew point meter. The gas will pass through a filter to capture rust and other particles coming from the pipeline.

\subsubsection{Injection With Compression}

Drawing No. EXGAZ-03 (see Appendix C) illustrates injection with compression. When the pressures in the pipeline and the cavern are equalized, injection continues by means of the injection compressors. The injection rate is $3.7 \times 10^{6} \mathrm{~m}^{3 / \text { day }}(130 \mathrm{MMcf} /$ day) at an inlet

pressure of 700 psi and an outlet pressure of 3,330 psi. Gas is cooled in an air cooler down to the ambient temperature of about $+38^{\circ} \mathrm{C}\left(100^{\circ} \mathrm{F}\right)$. The cooling will continue by means of a refrigeration unit down to a temperature of $10^{\circ} \mathrm{C}\left(50^{\circ} \mathrm{F}\right)$. At the same time, gas is circulated from the caverns by means of the circulation compressor through an air cooler and a refrigeration unit, in order to cool the storage gas; thus, increasing the working gas volume. The circulation flow rate is maximum at $260 \mathrm{MMcf} /$ day, and the temperature of the gas going back to the storage is $10^{\circ} \mathrm{C}\left(50^{\circ} \mathrm{F}\right)$. The goal is to have a final gas temperature close to the ambient rock temperature (see Section 5.1.6). In order to achieve maximum efficiency, the cool gas is injected at the bottom of the cavern and warmer gas is taken out at the top (see Figure 5-17).

\subsubsection{Withdrawal With Reduction}

Drawing No. EXGAZ-04 (see Appendix C) illustrates withdrawal with pressure reduction. During withdrawal, gas is removed from the cavern by free flow down to the pipeline pressure. The withdrawal capacity is $7.4 \times 10^{6} \mathrm{~m}^{3} /$ day (260 MMscf/day). At the same time, the same amount of gas is circulated and heated in order to maintain a temperature above $0^{\circ} \mathrm{C}$ inside the 
cavern. During the circulation, warm gas is injected at the bottom of the cavern in order to avoid any cold areas (see Figure 5-18).

RSI-835-99-107

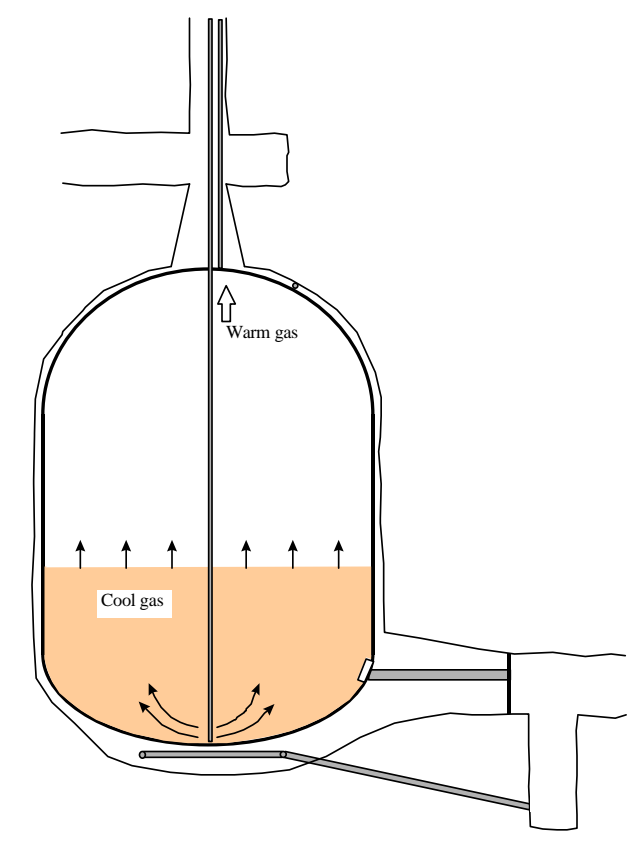

Figure 5-17. Circulation Cooling During Injection.

RSI-835-99-108

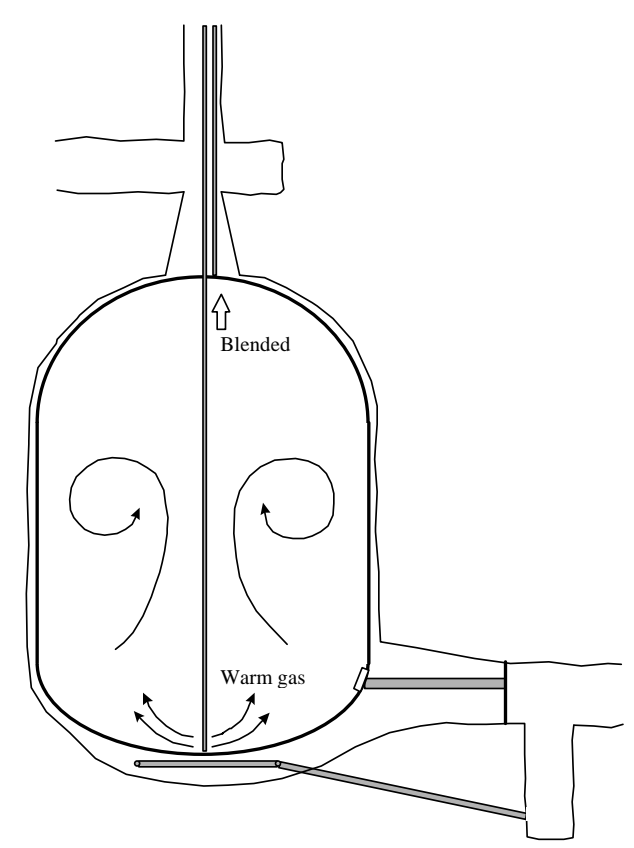

Figure 5-18. Circulation Heating During Withdrawal. 
Before pressure reduction, the gas flows through a filter, protecting the pressure reduction valves from water or rust particles. The gas is heated before the pressure reduction to avoid low temperatures in the pipeline.

\subsubsection{Withdrawal With Compression}

Drawing No. EXGAZ-05 (see Appendix C) illustrates withdrawal with compression. When the cavern pressure level reaches the pipeline pressure, gas will continue to be withdrawn by means of the main compressors. In this case, the installed compressor power is utilized to reduce the base gas requirement by going below the pipeline pressure in the cavern. The compressors can be utilized to withdraw gas down to a pressure of 38 bar ( 555 psi) and inject it into the pipeline at a maximum pressure of 84 bar (1,215 psi).

\subsubsection{Circulation Cooling/Heating}

Drawing No. EXGAZ-06 (see Appendix C) illustrates circulation cooling and heating. This case is used if the temperature for some reason should need to be adjusted. This can be used for optimization of the storage operation.

\subsubsection{Aboveground Facilities Layout and Main Equipment}

The layout for the aboveground facilities is shown in Drawing No. EXGAZ-07 (see Appendix C). The facility consists of four headshafts - one for each cavern. The shafts contain two gas pipes: one for injection and one for withdrawal. Each cavern can be operated separately.

The compressor station consists of two electric motor-driven, two-stage reciprocating compressors for injection and one circulation compressor. Adjacent to the compressors, air coolers for cooling by ambient air are installed. In line with the air cooler, the refrigeration unit, which is cooling the gas to $10^{\circ} \mathrm{C}$, is installed.

The metering and pressure reduction consists of two outlet trains with filters, heaters, and pressure reduction valves. "Slam-shuts" will ensure that the storage pressure does not overpressure the pipeline. Heat for warming the gas is provided from a boiler central with a water/glycol system. Gas analysis instruments are installed to measure the gas composition and the dew point.

The facility is controlled from a control room which also includes staff facilities. The operation is controlled by a PLC system. Electricity is supplied through a high-voltage transformer and switch gear. The aboveground facilities will include the support systems listed below: 
- Air compressors for instrument air

- ESD system, including venting of the compressor system

- Gas detectors

- Fire detectors

- Lubrication oil storage tank

- Glycol system

- Waste oil tank

- UPS system. 


\subsection{COST ESTIMATE}

\subsection{INTRODUCTION}

This chapter gives the investment and operational cost for a four- and an eight-cavern LRC storage facility. A time schedule for the project is also presented. The costs are believed to be accurate for December 1998 for a location in New England. The New England area is selected for the cost estimate as it is the most promising area from a market point of view (see Chapter 7.0). The primary difference between the cost of an LRC in New England and the Southeast would relate to differences in labor rates.

To be able to handle all uncertainties linked to the cost, a probabilistic approach has been chosen for presenting the cost. The result is a cost-versus-probability curve that is believed to give a truer cost picture than just one single value.

The cost achieved in the United States for the rock excavation has been compared with the Scandinavian cost for similar excavation. This comparison is presented in Section 6.2.6.

A cost estimate that is 100 percent accurate is impossible to develop for any major project. The cost level will depend on design parameters but also local geological conditions as well as the competition and the general situation in the construction market. A probabilistic model called Multirisk is used to handle the uncertainties. Multirisk has been used by Sycon in many projects in the past.

The general factors that will impact the cost level of an LRC storage include:

1. Design

2. Geology

3. Production methods

4. Permitting

5. Competition

6. Location.

The anticipated design of a four-cavern storage for the cost estimate is presented in Chapter 5.0.

The anticipated geology is described in Chapters 4.0 and 5.0. An RMR value of at least 70 is anticipated. This represents competent rock with a low requirement for rock support. The water influx is anticipated to be low. 
The production methods used are well recognized by United States rock excavation contractors. Improvements can be made using, for example, Scandinavian methods.

The cost for permitting is based on "normal" requirements for underground storage.

The cost estimate is made without consideration of competition. It is, therefore, likely that the cost can be lowered when the project is ready to be bid.

An LRC project is a very labor-intensive construction project. The location where the LRC is being constructed will, therefore, have a significant impact on construction costs because of variations in labor union issues. This uncertainty is handled in the probabilistic model at a general influence level.

The costs for the LRC facility are divided into three groups: preconstruction cost, below ground cost, and aboveground cost. For the calculation of these costs, each item in each group has been assigned a low, likely, and high value. The items are regarded as independent of each other. To combine the items for a total project cost, Multirisk has been used. For the below ground group, general conditions are also applied for competition and location impact.

\subsection{INVESTMENT COST FOR A FOUR-CAVERN FACILITY}

The four-cavern storage facility will have the characteristics below:

$\begin{array}{lll}\text { Number of caverns } & 4 & \\ \text { Geometrical volume } & 320,000(11.3 \mathrm{MMcf}) & \mathrm{m}^{3} \\ \text { Working gas } & 74 \times 10^{6}(2.6 \mathrm{Bscf}) & \mathrm{m}^{3} \\ \text { Gas withdrawal, maximum } & 7.4 \times 10^{6}(260 \mathrm{MMscf} / \mathrm{d}) & \mathrm{m}^{3} / \mathrm{d} \\ \text { Gas injection } & 3.7 \times 10^{6}(130 \mathrm{MMscf} / \mathrm{d}) & \mathrm{m}^{3} / \mathrm{d} \\ \text { Gas circulation, maximum } & 7.4 \times 10^{6}(2.60 \mathrm{MMscf} / \mathrm{d}) & \mathrm{m}^{3 / \mathrm{d}}\end{array}$

The calculated investment cost for the three groups: preconstruction, below ground, and aboveground, is presented below. The cost is presented as a probabilistic S-curve. In the curve, the cost will depend on the confidence level that is chosen for the project. An 80 percent probability is what is normally chosen for investment decisions. This means that the probability that the cost is lower than this value is 80 percent. The graphs below show the S-curves for the three groups of costs. Also, the top ten uncertainties are indicated. These are the items in the cost calculation in which the cost portion combined with the uncertainty create the greatest impact on the total cost. 


\subsubsection{Preconstruction Cost}

The preconstruction cost consists of:

- Permits

- Design and tender documents

- Site selection and geologic evaluation.

The S-curve for the preconstruction cost is presented in Figure 6-1, and the top ten risks are presented in rank-order in Figure 6-2. The cost with 80 percent probability for preconstruction is $\$ 5,800,000$. The most uncertain item is the cost for permitting.

RSI-835-99-109

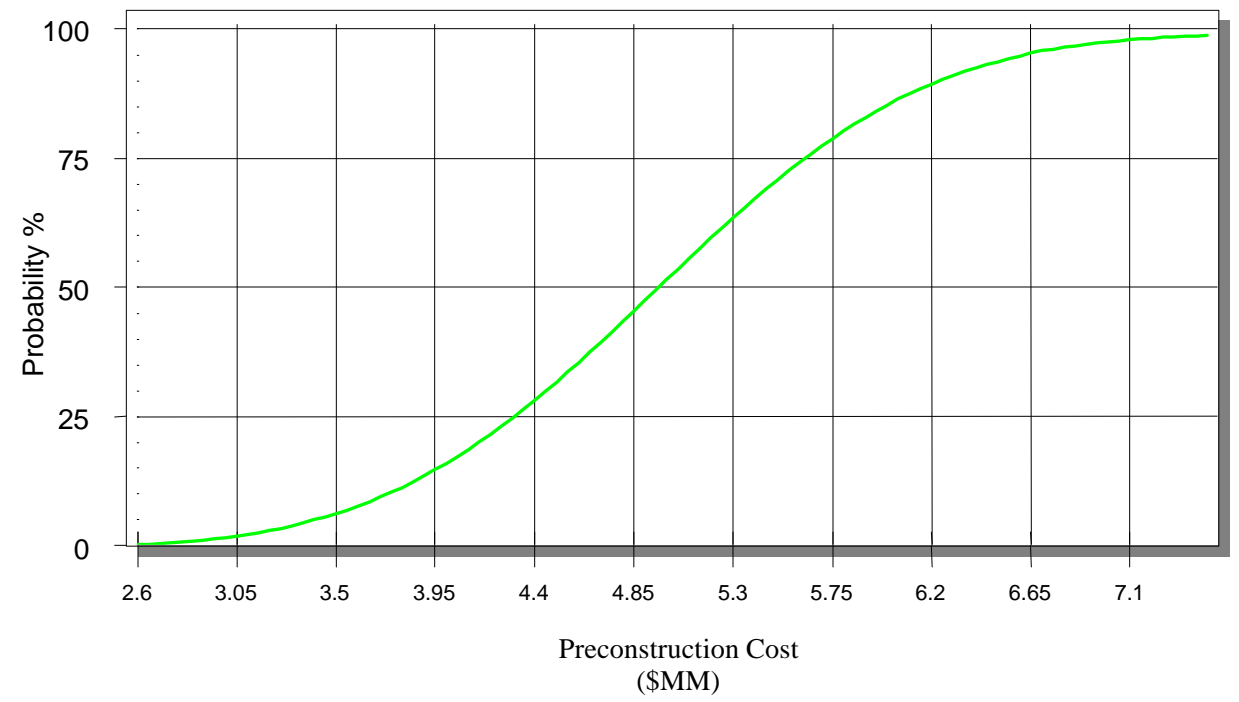

Figure 6-1. Preconstruction Investment Cost. 
RSI-835-99-110

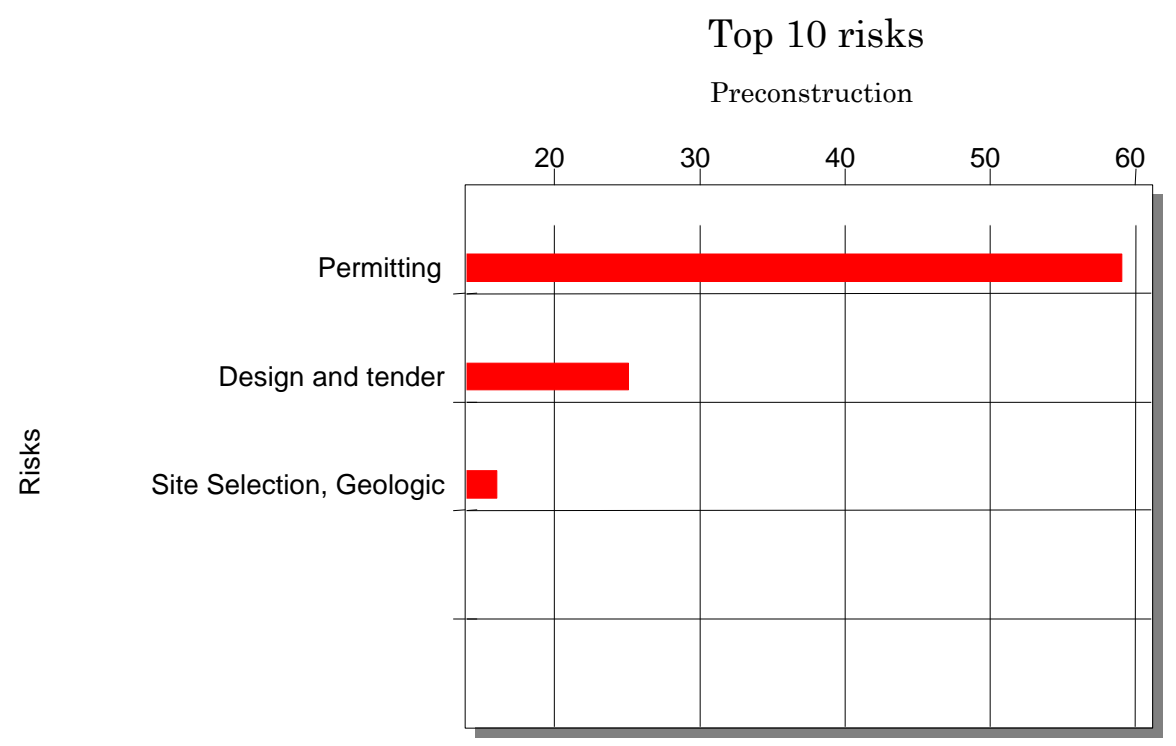

Figure 6-2. Uncertainties for Preconstruction Cost.

\subsubsection{Below Ground Cost}

The below ground cost includes:

- Site preparation

- Spiral access tunnels

- Cavern access tunnels

- Above cavern tunnels

- Caverns

- Cavern shafts

- Concrete barriers

- Water drainage pipes

- Rock support

- Shotcrete

- Grouting 
- General service

- General and administrative labor

- General and administrative expenses

- Insurance and bonding

- Equipment purchase and rent

- Electrical consumption

- Water treatment plant.

The S-curve for the below ground portion of the LRC project is illustrated in Figure 6-3 and shows that the cost with 80 percent probability for below ground construction is $\$ 125,500,000$.

RSI-835-99-111

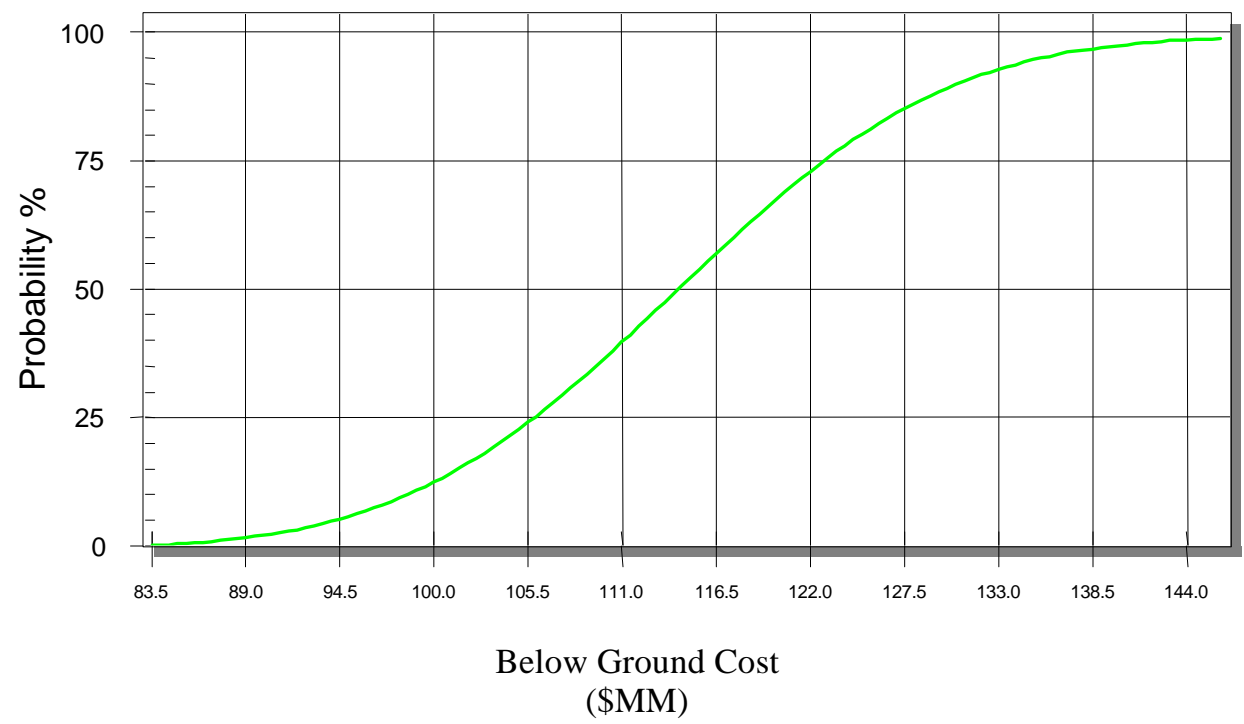

Figure 6-3. Below Ground Investment Cost.

The three dominating uncertainties shown in Figure 6-4 are competition, location, and the steel lining. In a tender procedure, there is always a span between the highest and lowest bid. A 30 percent span between the highest and the lowest is not unusual. Since the cost estimation is done without any competition, it is reasonable to believe that the cost will go down during bidding. In the model, a likely reduction has been set to 5 percent with a span from -15 percent to +10 percent. 


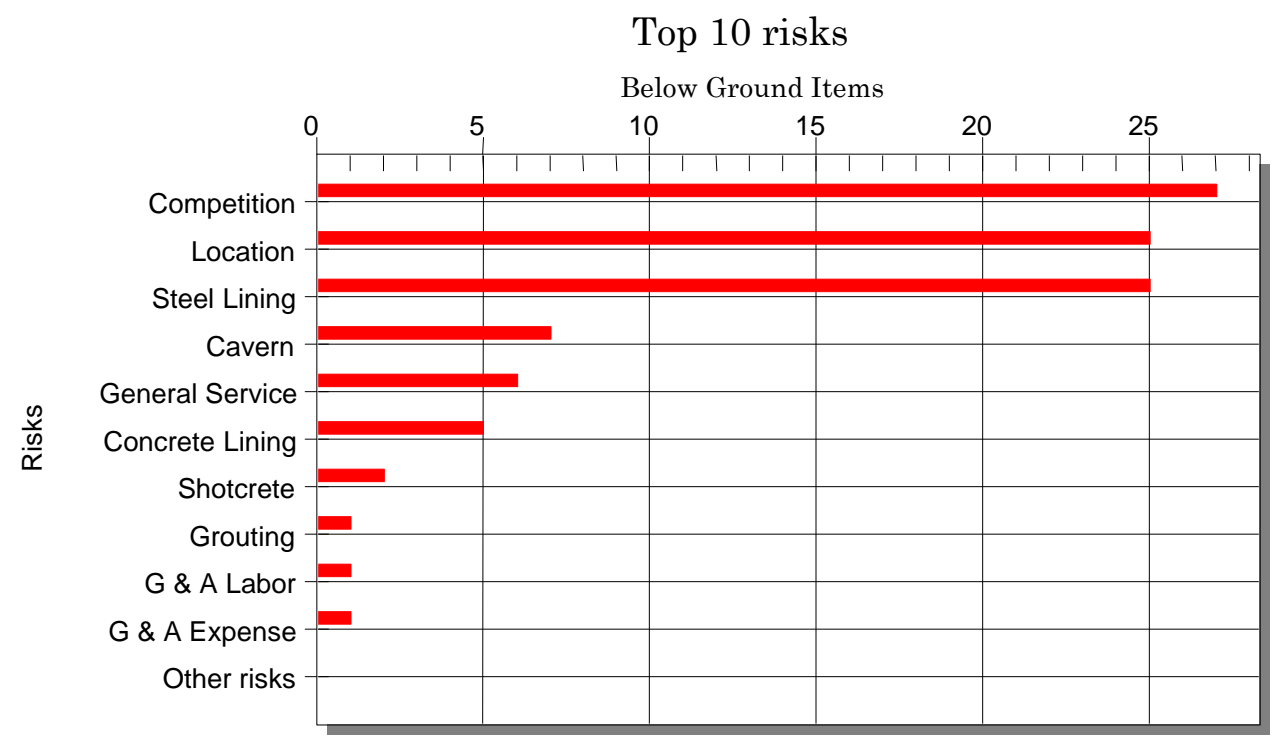

Figure 6-4. Largest Uncertainties for Below Ground Cost.

The second major uncertainty factor has to do with the project location. This parameter is related to the labor union situation and the wages at the location where the project might be built. It is anticipated that there will be a difference between the individual states in New England. In the model, a likely reduction has been set to 0 percent with a span from -15 percent to +10 percent.

The third major uncertainty concerns the steel liner. This uncertainty is related to the production cost of the liner. This type of liner has never been developed before; thus, there is no experience base. The first steel liner will be built in the demonstration plant in Sweden.

The analysis is based on the assumption that the site has been selected and the geologic investigations are made in the preconstruction phase. The uncertainties associated with rock excavation are higher prior to the geological investigation.

\subsubsection{Aboveground Cost}

The aboveground facilities cost includes:

- Pipeline connection of one-half mile

- Power supply 
- Compressor station

- Station piping

- Workshops and warehouses

- Permits, legal fees, insurance.

The cost with 80 percent probability for aboveground construction is $\$ 31,000,000$ (see Figure 6-5). The largest uncertainty, as shown in Figure 6-6, is related to the compressor equipment and installation of equipment and piping in the compressor station as these are the dominating costs.

RSI-835-99-113

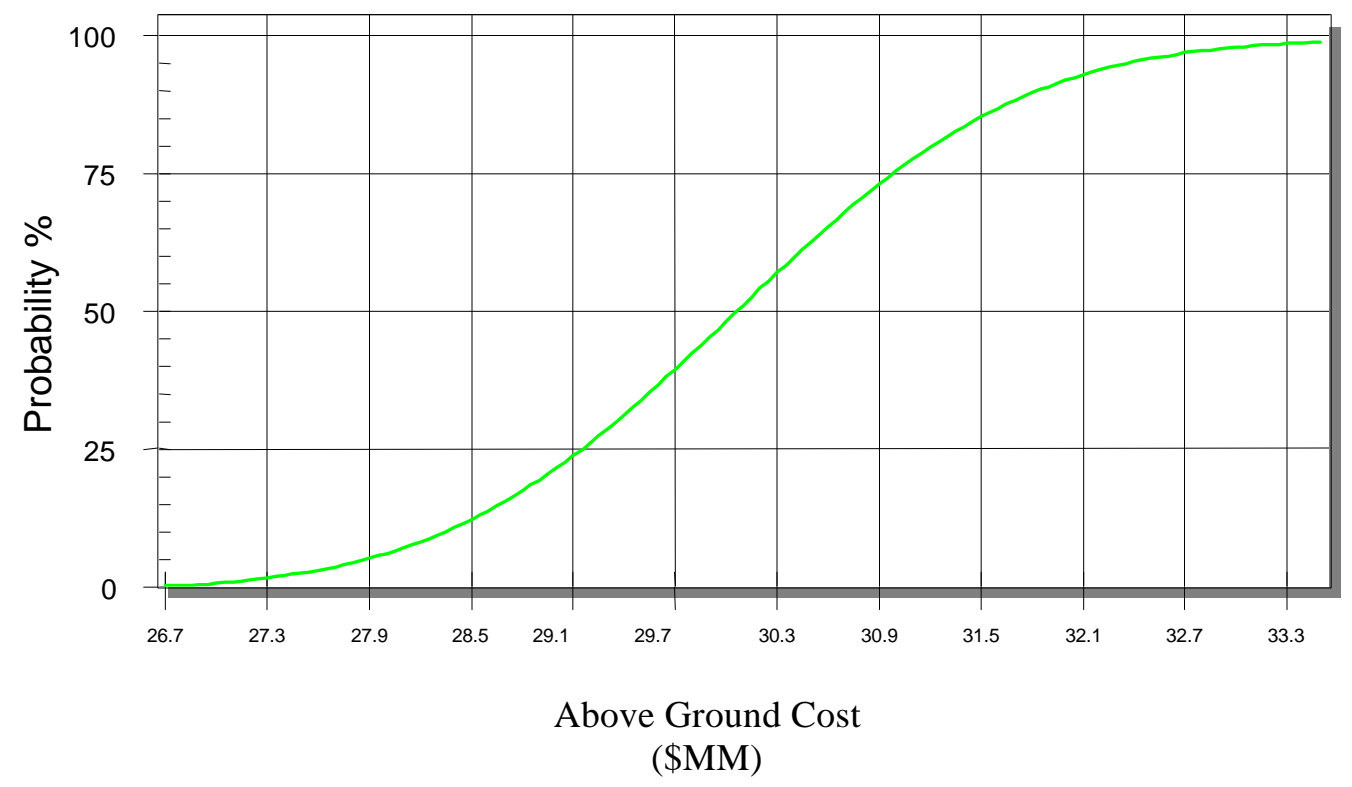

Figure 6-5. Aboveground Investment Cost. 


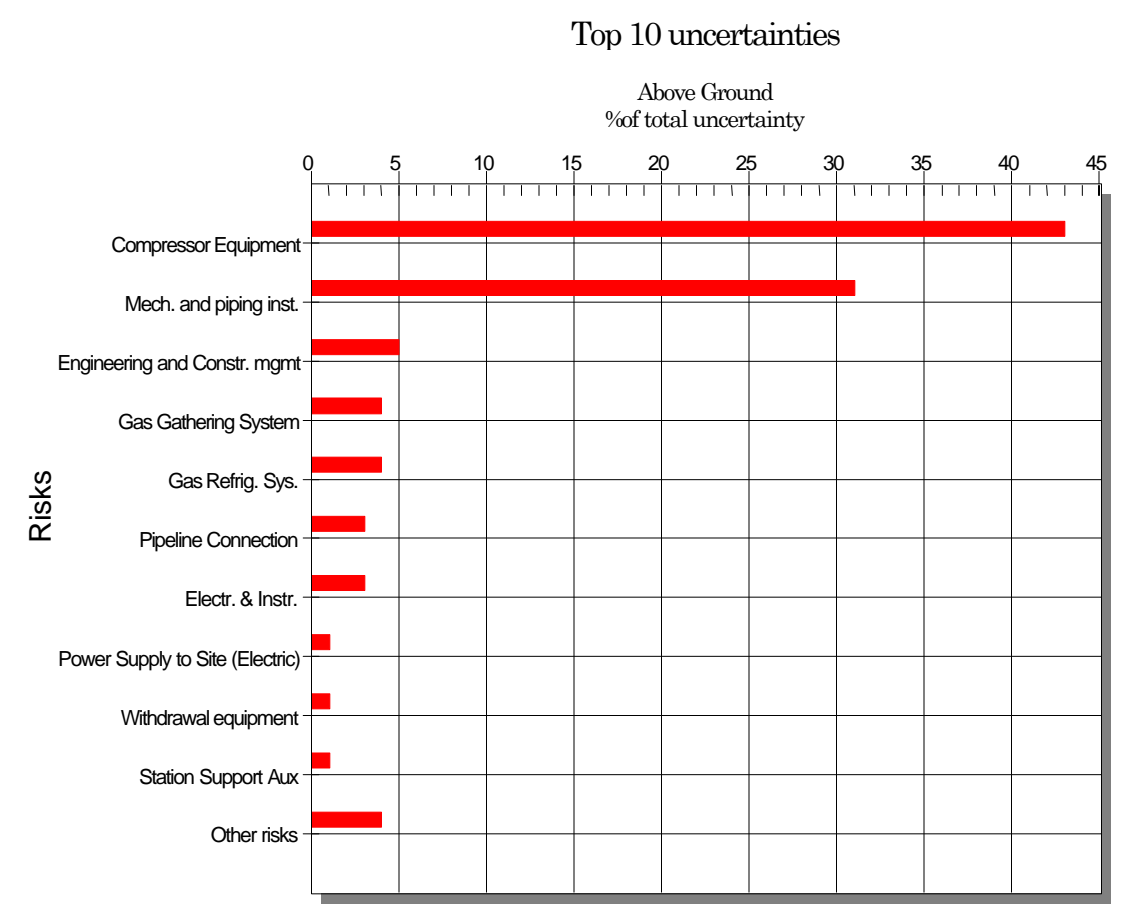

Figure 6-6. Largest Uncertainties for Aboveground Cost.

\subsubsection{Total Investment Cost for a Four-Cavern Storage Facility}

The total investment cost includes the cost from each of the three main cost groupings: preconstruction, below ground, and aboveground, together with base gas cost and Allowance for Funds During Construction (AFDC). The base gas cost of $\$ 1,250,000$ is calculated assuming a gas volume of $0.5 \mathrm{bcf}$ and a gas price of $\$ 2.5$. The AFDC is calculated assuming an interest rate 7.5 percent and the project time schedule in Section 6.2.1. The total investment cost for a fourcavern storage facility (with an 80 percent probability) is shown in Table 6-1.

Table 6-1. Investment Cost for a FourCavern LRC Facility

\begin{tabular}{||l|c||}
\hline $\begin{array}{c}\text { Cost } \\
\text { Component }\end{array}$ & $\begin{array}{c}\text { Investment } \\
\text { Cost } \\
\mathbf{( \$ 1 , 0 0 0 )}\end{array}$ \\
\hline \hline Preconstruction & 5,800 \\
\hline Below ground & 125,550 \\
\hline Aboveground & 31,000 \\
\hline Base gas & 1,250 \\
\hline AFDC & 18,700 \\
\hline Total & $\mathbf{1 8 2 , 3 0 0}$ \\
\hline
\end{tabular}




\subsubsection{Operating Cost for a Four-Cavern Storage Facility}

The operating cost for a four-cavern storage facility with one cycle is presented in Table 6-2. With several cycles, the fixed operational cost will be constant except for compressor maintenance, which will increase with the run time. The variable cost is proportional to the number of cycles.

Table 6-2. Annual Operating Cost for a Four-Cavern LRC Facility

\begin{tabular}{||l|c||}
\hline \multicolumn{1}{|c|}{ Cost Component } & $\begin{array}{c}\text { Annual } \\
\text { Operating Cost } \\
\mathbf{( \$ 1 , 0 0 0 )}\end{array}$ \\
\hline \hline Fixed cost: & 600 \\
Personnel (7) & 200 \\
Maintenance compressors & 100 \\
Insurance & 100 \\
Fixed maintenance & \\
\hline Variable cost for one cycle: & 500 \\
Electricity for injection and cooling plus fuel gas & $\mathbf{1 , 5 0 0}$ \\
\hline Total cost for one cycle & \\
\hline
\end{tabular}

The Skallen demonstration plant in Sweden will be built with a remote-control capability. Personnel operating the main pipeline will also operate the storage. This manpower approach is also possible with a four-cavern facility, which would cut the cost for personnel shown.

\subsubsection{Total Investment Cost for an Eight-Cavern Storage Facility}

The eight-cavern storage facility will have the characteristics below:

$\begin{array}{lll}\text { Number of caverns } & 8 & \\ \text { Geometrical volume } & 640000(22.6 \mathrm{MMcf}) & \mathrm{m}^{3} \\ \text { Working gas } & 148 \times 10^{6}(5.2 \mathrm{Bscf}) & \mathrm{m}^{3} \\ \text { Gas withdrawal, maximum } & 14.8 \times 10^{6}(560 \mathrm{MMscf} / \mathrm{d}) & \mathrm{m}^{3} / \mathrm{d} \\ \text { Gas injection } & 7.4 \times 10^{6}(260 \mathrm{MMscf} / \mathrm{d}) & \mathrm{m}^{3} / \mathrm{d} \\ \text { Gas circulation, maximum } & 14.8 \times 10^{6}(560 \mathrm{MMscf} / \mathrm{d}) & \mathrm{m}^{3} / \mathrm{d}\end{array}$


The design will basically include two modules of four caverns each with a separate access tunnel. The two four-cavern modules can be built simultaneously or sequentially. The cost estimate has been revised for an eight-cavern based on the two four-cavern modules being built at the same time. This will create some synergies regarding indirect construction cost that are more related to the construction time than to the size; e.g., supervision, general service, water treatment, and operation. The cost increase for preconstruction of an eight-cavern facility instead of a four-cavern facility is small. The cost estimate for an eight-cavern facility, with an 80 percent probability, is presented in Table 6-3, together with the four-cavern facility cost multipliers.

Table 6-3. Investment Cost for an Eight-Cavern LRC Facility

\begin{tabular}{||l|c|c||}
\hline \multicolumn{1}{|c|}{$\begin{array}{c}\text { Cost } \\
\text { Component }\end{array}$} & $\begin{array}{c}\text { Investment } \\
\text { Cost } \\
\mathbf{( \$ 1 , 0 0 0 )}\end{array}$ & $\begin{array}{c}\text { Four-Cavern Facility } \\
\text { Multiplier }\end{array}$ \\
\hline \hline Preconstruction & 7,000 & 1.21 \\
\hline Below ground & 239,000 & 1.90 \\
\hline Aboveground & 60,000 & 1.94 \\
\hline Base gas & 2,500 & 2.00 \\
\hline AFDC & 35,200 & 1.88 \\
\hline \multicolumn{1}{|c|}{ Total } & $\mathbf{3 4 3 , 7 0 0}$ & $\mathbf{1 . 8 9}$ \\
\hline
\end{tabular}

\subsubsection{Operating Cost for an Eight-Cavern Storage Facility}

The operating cost for an eight-cavern storage facility is presented in Table 6-4. The operating cost is 1.87 times the four-cavern facility cost.

Table 6-4. Annual Operating Cost for an Eight-Cavern LRC Facility

\begin{tabular}{||l|c||}
\hline \multicolumn{1}{|c|}{ Cost Component } & $\begin{array}{c}\text { Annual } \\
\text { Operating Cost } \\
\mathbf{( \$ 1 , 0 0 0 )}\end{array}$ \\
\hline \hline Fixed cost: & 1,700 \\
Personnel (11) & 400 \\
Maintenance compressors & 150 \\
Insurance & 150 \\
Fixed maintenance & \\
\hline Variable cost for one cycle: & 1,100 \\
Electricity for injection and cooling plus fuel gas & $\mathbf{2 , 8 0 0}$ \\
\hline Total cost for one cycle & \\
\hline
\end{tabular}




\subsubsection{Comparison of Investment Cost in the United States to Investment Cost in Scandinavia}

The investment cost for a four-cavern facility in the United States has been compared to the cost for a similar facility in Scandinavia. The Scandinavian cost was calculated with the SECON-model (see Chapter 7.0 and Appendix D). The cost comparison is presented in Table 6-5.

Table 6-5. Investment Cost Comparison for LRC Storage Between the United States and Scandinavia

\begin{tabular}{||c|c|c|c||}
\hline $\begin{array}{c}\text { Cost } \\
\text { Component }\end{array}$ & U.S. Cost & $\begin{array}{c}\text { Scandinavian } \\
\text { Cost }\end{array}$ & $\begin{array}{c}\text { Ratio of } \\
\text { U.S. Cost to } \\
\text { Scandinavian } \\
\text { Cost }\end{array}$ \\
\hline \hline & \multicolumn{2}{|c|}{$\$ 1,000$} & \\
\hline Preconstruction Cost & 5,800 & 5,800 & 1.00 \\
\hline Below Ground Cost & 125,550 & 54,600 & 2.33 \\
\hline Aboveground Cost & 31,000 & 34,000 & 0.91 \\
\hline Total & $\mathbf{1 6 2 , 3 5 0}$ & $\mathbf{9 4 , 4 0 0}$ & $\mathbf{1 . 7 2}$ \\
\hline
\end{tabular}

As shown in Table 6-5, there is a great difference in the below ground cost between the United States and Scandinavia. The cost differences for some of the more significant cost items are illustrated in Table 6-6.

Table 6-6. Cost Comparison for LRC Storage Between the United States and Scandinavia for Certain Below Ground Components

\begin{tabular}{||c|c||}
\hline $\begin{array}{c}\text { Facility } \\
\text { Component }\end{array}$ & $\begin{array}{c}\text { United States/ } \\
\text { Scandinavia Cost }\end{array}$ \\
\hline \hline Tunnels & 3.21 \\
\hline Caverns & 3.39 \\
\hline Shafts & 1.66 \\
\hline
\end{tabular}

The cost differences are caused mainly by different union rules in the United States compared to Scandinavia. These rules significantly impact a labor-intensive project such as excavation of a rock cavern. The tables above indicated that there is a great potential for reducing the project cost. There should be some room for negotiating labor union contracts. 


\subsubsection{Cost of Service}

The cost of service is calculated using the model presented in Chapter 7.0 and Appendix D. The cost of service calculation shown in Table 6-7 is based on the following conditions:

$\begin{array}{ll}\text { Interest rate } & 8.4 \% \\ \text { Return on equity } & 14.0 \% \\ \text { Equity debt ratio } & 25 / 75 \\ \text { Federal tax } & 36.0 \% \\ \text { State tax } & 8.25 \%\end{array}$

Property tax $\quad 1.0 \%$ (Calculated on the entire investment, including that below ground) Cost of electricity and fuel are included in the cost of service shown in Table 6-7.

Table 6-7. Cost of Service per Deliverability for LRC Storage

\begin{tabular}{||c|c|c|c|c||}
\hline Facility & $\begin{array}{c}\text { Deliverability } \\
\text { MMcf/d }\end{array}$ & $\$ / \mathbf{M c f} / \mathbf{d} /$ Month & $\begin{array}{c}\text { Annual Cost } \\
\text { for Capacity } \\
\text { at 1 Cycle } \\
\mathbf{\$} / \mathbf{M c f})\end{array}$ & $\begin{array}{c}\text { Annual Cost } \\
\text { for Capacity } \\
\text { at 12 Cycles } \\
\text { (\$/Mcf) }\end{array}$ \\
\hline \hline Four-cavern facility & 260 & $\$ 9.79$ & 11.75 & 1.28 \\
\hline Eight-cavern facility & 520 & $\$ 9.23$ & 11.07 & 1.21 \\
\hline
\end{tabular}

\subsubsection{Cost Reduction Potential}

Sycon and Gaz de France are presently working with cost reductions for the LRC concept. The evaluations include changes in design, such as increased height and width of the caverns, as well as more economical production methods for mining of the caverns. Options with gas cooling and higher gas pressure are also being evaluated.

The design changes are evaluated technically and economically in an ongoing process with a feasibility target price of $\$ 8 / \mathrm{Dth} / \mathrm{d} /$ month.

\subsubsection{Project Schedule}

Figure 6-7 illustrates the project schedule for a four-cavern storage facility. The schedule is based on a project construction start in January 1999. The project schedule for the LRC demonstration plant in Sweden is also shown for information.

The total project time is about 6 years. However, two caverns can be commissioned approximately 1 year before total project completion. 


\begin{tabular}{|c|c|c|c|c|c|c|c|c|c|c|c|}
\hline \multirow[b]{2}{*}{ ID } & \multirow[b]{2}{*}{ Activity } & \multicolumn{2}{|c|}{1999} & 2000 & 2001 & 2002 & 2003 & 2004 & 2005 & \multicolumn{2}{|c|}{2006} \\
\hline & & $\mathrm{H} 1$ & $\mathrm{H} 2$ & \begin{tabular}{|l|l|}
$\mathrm{H} 1$ & $\mathrm{H} 2$ \\
\end{tabular} & \begin{tabular}{l|l|}
$\mathrm{H} 1$ & $\mathrm{H} 2$ \\
\end{tabular} & \begin{tabular}{|l|l|}
$\mathrm{H} 1$ & $\mathrm{H} 2$ \\
\end{tabular} & \begin{tabular}{|l|l|}
$\mathrm{H} 1$ & $\mathrm{H} 2$ \\
\end{tabular} & \begin{tabular}{|l|l|}
$\mathrm{H} 1$ & $\mathrm{H} 2$ \\
\end{tabular} & \begin{tabular}{|l|l|}
$\mathrm{H} 1$ & $\mathrm{H} 2$ \\
\end{tabular} & $\mathrm{H} 1$ & $\mathrm{H} 2$ \\
\hline 1 & Pre- Construction & & & & & & & & & & \\
\hline 2 & Permitting & & & & & & & & & & \\
\hline 3 & SiteSelection and Design & & & & & & & & & & \\
\hline 4 & Below Ground Construction & & & & & & & & & & \\
\hline 5 & Excavation of tunnels & & & & & & & & & & \\
\hline 6 & Excavation of Shafts and 2 first caverns & & & & & & & & & & \\
\hline 7 & Lining of 2 first caverns & & & & & & & & & & \\
\hline 8 & Test and commission of 2 first caverns & & & & & & & & & & \\
\hline 9 & Filling of first 2 caverns & & & & & & & & & & \\
\hline 10 & Excavation of 2 last caverns & & & & & & & & & & \\
\hline 11 & Lining of 2 last caverns & & & & & & & & & & \\
\hline 12 & Test and commission of 2 last caverns & & & & & & & & & & \\
\hline 13 & Filling of 2 last caverns & & & & & & & & & 8-3 & \\
\hline 14 & Above Ground Construction & & & & & & & & & & \\
\hline 15 & & & & & & & & & & & \\
\hline 16 & Demonstration Plant in Skallen, Sweden & & & & & & & & & & \\
\hline 17 & Construction of Demo-plant & & & & & & & & & & \\
\hline 18 & Test of Demo-plant & & & & & & & & & & \\
\hline
\end{tabular}

Figure 6-7. Time Schedule for a Four-Cavern LRC Storage. 


\subsection{ECONOMIC COMPARISON OF LRC TO ALTERNATIVES}

\subsection{INTRODUCTION}

In this chapter, the LRC is compared to other storage alternatives and pipeline transportation. The comparison is made for two regions: the Northeast, covering New England, and the Southeast, covering Georgia, North Carolina, and South Carolina. Both of these areas have geology suitable for LRC and both are facing the highest gas consumption rates in the country, leading to a tremendous increase in the need for flexibility and modulation. The growth is mainly driven by power generation and climate conditions that generate strong peak demands either in winter (Northeast and Southeast) or both in winter and in summer (Southeast).

The Northeast area is located at the far end of the transmission pipeline systems that originate in the gas production regions of the Gulf of Mexico. The gas has to be transported over long distances to reach the East Coast market. Thus, it is expensive to transport the gas with a low load factor; i.e., it is uneconomical to cover the consumption variation with the pipeline. The distance to the Southeast area is shorter, but the pipeline transportation capacity is limited.

There is no salt cavern storage in the two subject areas. The closest salt storage is located in the middle Atlantic for the Northeast and in Louisiana, Mississippi, and Alabama for the

Southeast. Furthermore, storage for modulation of a power plant has to be located very close to the facility to be able to function properly. Long transmission distances will create problems in the gas supply due to pressure drop in the system.

LNG peak-shaving facilities, which have been the only storage means in the two areas for a long time, have three major drawbacks:

1. The cost is high.

2. They are not very well perceived by the population, making approval for new projects difficult.

3. An LNG liquefaction plant can generally only provide one cycle per year, depending on the investment for liquefaction equipment. Vaporization plants, which are recharged by truck delivery, can be cycled. However, they then have to rely on a larger liquefaction unit or an import terminal located within a reasonable distance. 


\subsection{THE NEW ENGLAND AREA}

Four pipelines run from the Gulf of Mexico to supply the area: The Tennessee pipeline, the Transcontinental/Algonquin pipeline, the Texas Eastern/Algonquin pipeline, and the Colombia Gulf/Colombia Gas/Algonquin pipeline. Another line, the Iroquois pipeline, supplies New England through the Canadian border from the TransCanada pipeline. The PNGTS receives gas from the TransCanada pipeline via the Montreal pipeline. One more line from Canada is projected: the M\&E pipeline. The M\&E pipeline will transmit gas from the Sable Island Project.

The storage option available today for the Northeast consumers (besides the option of buying peak gas from LNG) is to utilize storage located in the Middle Atlantic.

\subsection{THE SOUTHEAST AREA}

The Transcontinental pipeline supplies this area with gas from the Gulf of Mexico. The SONAT pipeline also provides the states of Georgia and South Carolina with gas. The lack of storage facilities in the Southeast is even more evident than in the Northeast. The storage that can be utilized is located in northern West Virginia or in Louisiana, Mississippi, or Alabama. This situation has favored the construction of the Pine Needle LNG plant.

\subsection{CASE STUDIES}

The economics of LRC will depend on the customers' load profile. To illustrate LRC use with different customer requirements, two cases have been evaluated. The cases are:

Case 1: Peak storage for one cycle each year. The most likely customers are marketers or LDCs that want to cover the risk associated with severe weather conditions.

Case 2: Multiple cycle storage that could be utilized by all types of customers: LDCs, transmission companies, power plants, or marketers. The average number of cycles for the five highest cycling facilities in the United States was between 3 and 3.5 cycles, for the heating season 97-98 [Energy Information Administration, 1998]. The number of cycles for the most active facilities has increased sharply during the 90s. During the heating season of 90-91, the average number of cycles for the five highest cycling facilities was 0.3 cycle. For this case, a three-cycle scenario is chosen.

The cases have been evaluated for the two areas encompassing New England and the Southeast. The economic model presented in Appendix D was utilized for the evaluation. 
The cost utilized in this comparison for LRC is the forecasted cost of $\$ 8 / \mathrm{Dth} / \mathrm{d} / \mathrm{month}$. This is a targeted cost for LRC, as discussed in Chapter 6.0.

\subsubsection{New England Area}

For this area, the possible pipeline transportation alternatives have been listed in Table 7-1.

Table 7-1. Cost Comparison for Various Storage Technologies

\begin{tabular}{||l|l|c||}
\hline \multirow{2}{*}{ In State } & \multicolumn{1}{|c|}{ Cost Basis } & \multicolumn{1}{c|}{$\begin{array}{c}\text { Cost } \\
\text { (\$/Dth/d/Month) }\end{array}$} \\
\hline \hline \multirow{3}{*}{ Naine } & Tennessee+Granite & 19.82 \\
\hline \multirow{3}{*}{ Massachusetts } & Tennessee & 17.15 \\
\cline { 2 - 4 } & Col.Gulf/Col.Gas/Tennessee & 14.96 \\
\cline { 2 - 4 } & Tennessee & 17.15 \\
\cline { 2 - 4 } & Col.Gulf/Col.Gas/Tennessee & 16.02 \\
\cline { 2 - 4 } & TransCanada/Iroquois/Tennessee & 27.53 \\
\cline { 2 - 4 } & TransCanada/Iroquois/Algonquin & 33.18 \\
\hline \multirow{3}{*}{ Tonnecticut } & Tennessee & 17.15 \\
\cline { 2 - 4 } & TransCanada/Iroquois & 33.61 \\
\cline { 2 - 4 } & Col.Gulf/Col.Gas/Tennessee & 16.02 \\
\cline { 2 - 4 } & Texas Eastern/Algonquin & 27.53 \\
\hline
\end{tabular}

A comparison has been made for a typical customer needing a deliverability of $30 \mathrm{MDth} / \mathrm{d}$. When comparing pipeline transportation and storage utilization, the Tennessee pipeline transportation rate has been utilized. The proposed storage in salt caverns at Tioga and the proposed LNG storage in Wells, Maine, have been used for the storage alternatives. It should be noted that the proposed LNG facility in Wells has been canceled. However, it should nonetheless serve as a reasonable comparison for possible alternatives. A small local LNG satellite tank has also been included for comparison. The satellite can only supply $6 \mathrm{MDth} / \mathrm{d}$ with refilling every day. The assumptions made for the evaluation of Cases 1 and 2 are given in Tables 7-2 and 7-3, respectively. The results of the evaluations are shown in Tables 7-4 and 7-5 for Cases 1 and 2, respectively. 
Table 7-2. Assumptions for Case 1

\begin{tabular}{||l|c|l||}
\hline \multicolumn{1}{|c|}{ Quantity } & Value & \multicolumn{1}{|c|}{ Units } \\
\hline \hline Needed deliverability & 30 & MDth/d \\
\hline Yearly gas volume & 300 & MDth \\
\hline Storage withdrawal time & 10 & $\mathrm{~d}$ \\
\hline Storage injection time & 200 & $\mathrm{~d}$ \\
\hline Storage rates: & & \\
\hline LRC & 8.0 & $\$ / \mathrm{Dth} / \mathrm{d} / \mathrm{month}$ \\
\hline Salt storage: & & \\
\hline Tioga (Zone 4) & 4.2 & $\$ / \mathrm{Dth} / \mathrm{d}$ \\
\hline LNG: & & \\
\hline Wells, Maine (Zone 6) & 6.4 & $\$ / \mathrm{Dth} / \mathrm{d} / \mathrm{month}$ \\
\hline LNG Satellite & 9.7 & $\$ / \mathrm{Dth} / \mathrm{d} / \mathrm{month}$ \\
\hline Transportation of LNG (Truck @ \$2.00/Dth) & 1.7 & $\$ / \mathrm{Dth} / \mathrm{d} / \mathrm{month}$ \\
\hline $\begin{array}{l}\text { Long haul firm transportation rate on Tennessee } \\
\text { (Zone 0-6) }\end{array}$ & 17.15 & $\$ / \mathrm{Dth} / \mathrm{d} / \mathrm{month}$ \\
\hline \hline
\end{tabular}

Table 7-3. Assumptions for Case 2

\begin{tabular}{||l|c|l||}
\hline \multicolumn{1}{|c|}{ Quantity } & Value & \multicolumn{1}{c|}{ Units } \\
\hline \hline Needed deliverability & 30 & MDth/d \\
\hline Yearly gas volume & 900 & MDth \\
\hline Storage withdrawal time & 10 & $\mathrm{~d}$ \\
\hline Storage injection time & 200 & $\mathrm{~d}$ \\
\hline Storage rates: & & \\
\hline LRC & 8.0 & $\$ / \mathrm{Dth} / \mathrm{d} / \mathrm{month}$ \\
\hline Salt storage: & & \\
\hline $\begin{array}{c}\text { Tioga (Zone 4) } \\
\text { LNG: }\end{array}$ & 4.2 & $\$ / \mathrm{Dth} / \mathrm{d} / \mathrm{month}$ \\
\hline Wells, Maine (Zone 6) & 6.4 & $\$ / \mathrm{Dth} / \mathrm{d} / \mathrm{month}$ \\
\hline Transportation of LNG (Truck @ \$2.00/Dth) & 1.7 & $\$ / \mathrm{Dth} / \mathrm{d} / \mathrm{month}$ \\
\hline $\begin{array}{l}\text { Long haul firm transportation rate on Tennessee } \\
\text { (Zone 0-6) }\end{array}$ & 17.15 & $\$ / \mathrm{Dth} / \mathrm{d} / \mathrm{month}$ \\
\hline
\end{tabular}


Table 7-4. Comparison of Transportation Cost of 300 MDth Yearly at a Deliverability of $30 \mathrm{MDth} / \mathrm{d}$ - Case 1

\begin{tabular}{||l|c|c|c|c|c||}
\cline { 2 - 6 } \multicolumn{1}{c|}{} & $\begin{array}{c}\text { Long-Haul } \\
\text { Firm } \\
\text { Transportation }\end{array}$ & $\begin{array}{c}\text { Tioga } \\
\text { Storage }\end{array}$ & Wells LNG & $\begin{array}{c}\text { LNG } \\
\text { Satellite(a) }^{(a)}\end{array}$ & LRC \\
\hline Transportation to storage & - & 233,000 & 600,000 & 600,000 & 308,000 \\
\hline Storage Cost & - & $1,512,000$ & $2,304,000$ & $3,500,000$ & $2,880,000$ \\
\hline Transportation to end customer & $6,174,000$ & $2,225,000$ & $1,217,000$ & -(a) & $1,217,000$ \\
\hline Total annual cost & $\mathbf{6 , 1 7 4 , 0 0 0}$ & $\mathbf{3 , 9 7 0 , 0 0 0}$ & $\mathbf{4 , 1 2 1 , 0 0 0}$ & -(a) & $\mathbf{4 , 4 0 5 , 0 0 0}$ \\
\hline $\begin{array}{l}\text { Total cost (per yearly gas } \\
\text { volume) }\end{array}$ & $\mathbf{2 0 . 6}$ & $\mathbf{1 3 . 2}$ & $\mathbf{1 3 . 7}$ & - -(a) & $\mathbf{1 4 . 7}$ \\
\hline $\begin{array}{c}\text { Cost compared to long-haul } \\
\text { firm transportation }\end{array}$ & & $\mathbf{- 2 , 2 0 4 , 0 0 0}$ & $\mathbf{- 2 , 0 5 3 , 0 0 0}$ & - -(a) & $\mathbf{- 1 , 7 6 7 , 0 0 0}$ \\
\hline $\begin{array}{c}\text { Total annual cost, } \\
\text { Direct connection }\end{array}$ & & & $\mathbf{4 , 1 0 0 , 0 0 0}$ & $\mathbf{3 , 1 8 8 , 0 0 0}$ \\
\hline $\begin{array}{c}\text { Cost compared to long haul } \\
\text { firm transportation with } \\
\text { direct connection }\end{array}$ & & & & $\mathbf{- 2 , 0 7 4 , 0 0 0}$ & $\mathbf{- 2 , 9 8 6 , 0 0 0}$ \\
\hline $\begin{array}{c}\text { Total cost (per yearly gas } \\
\text { volume) }\end{array}$ & & & $\mathbf{1 3 . 7}$ & $\mathbf{1 0 . 6 3}$ \\
\hline
\end{tabular}

(a) $\operatorname{Max} 6 \mathrm{MDth} / \mathrm{d}$.

The cost for injection and withdrawal are comparably small for all alternatives, and are thus, neglected in this comparison.

The conclusions that can be drawn from these tables are:

- LRC has possibilities to lower the cost for transportation of gas from the Gulf of Mexico to the New England area.

- The cost for LRC is a bit higher than the proposed alternatives for a one-cycle operation. However, for some operations, such as power plant hourly peaks, salt caverns located in Tioga may cause problems for the transmission company due to pressure drop in the transmission line. LRC could then be used for pipeline pressure balancing.

- For the three-cycle case, LRC competes with firm transportation and LNG.

- If the LRC storage can be located so that a direct connection with the end customer, or if back haul delivery can be utilized, the LRC storage competes with all of the alternatives. 
Table 7-5. Comparison of Transportation Cost of 900 MDth Yearly at a Deliverability of $30 \mathrm{MDth} / \mathrm{d}$ - Case 2

\begin{tabular}{|c|c|c|c|c|c|}
\hline & \begin{tabular}{|c} 
Long-Haul \\
Firm \\
Transportation
\end{tabular} & $\begin{array}{l}\text { Tioga } \\
\text { Storage }\end{array}$ & Wells LNG & $\begin{array}{c}\text { LNG } \\
\text { Satellite }^{(a)}\end{array}$ & LRC \\
\hline Transportation to storage & - & 233,000 & $1,800,000$ & $1,800,000$ & 308,000 \\
\hline Storage Cost & - & $1,512,000$ & $2,304,000$ & $3,500,000$ & $2,880,000$ \\
\hline Transportation to end customer & $6,174,000$ & $2,225,000$ & $1,217,000$ & -(a) & $1,217,000$ \\
\hline Total annual cost & $6,174,000$ & $3,970,000$ & $5,321,000$ & -(a) & $4,405,000$ \\
\hline $\begin{array}{l}\text { Total cost (per yearly gas } \\
\text { volume) }\end{array}$ & 6.9 & 4.4 & 5.9 & -(a) & 4.9 \\
\hline $\begin{array}{l}\text { Cost compared to long-haul } \\
\text { firm transportation }\end{array}$ & & $-2,204,000$ & $-853,000$ & -(a) & $-1,767,000$ \\
\hline $\begin{array}{l}\text { Total annual cost, } \\
\text { Direct connection }\end{array}$ & & & & $5,300,000$ & $3,188,000$ \\
\hline $\begin{array}{l}\text { Cost compared to long haul } \\
\text { firm transportation with } \\
\text { direct connection }\end{array}$ & & & & $-874,000$ & $-2,986,000$ \\
\hline $\begin{array}{l}\text { Total cost (per yearly gas } \\
\text { volume) }\end{array}$ & & & & 5.9 & 3.5 \\
\hline
\end{tabular}

(a) Max $6 \mathrm{MDth} / \mathrm{d}$.

\subsubsection{Southeast Area}

Fewer specific alternatives exist in the Southeast for cost comparison. However, it is clear that the Southeast area is closer to the Gulf of Mexico; thus, the transportation cost for gas from the production area to the southern market is lower than transportation to the New England market.

The TRANSCO rates for firm transportation from production areas (Zone 1-3) are \$6-7 Dth/d/month for transportation into Alabama and Georgia (Zone 4). Transportation costs into South Carolina and North Carolina (Zone 5) are \$9-10 Dth/d/month. Transportation cost inside Zone 4 is $\$ 5 \mathrm{Dth} / \mathrm{d} / \mathrm{month}$, and the cost inside Zone 5 is $\$ 4 \mathrm{Dth} / \mathrm{d} / \mathrm{month}$.

The available storage alternative in the southern market area is the Pine Needle LNG storage. The demand charge for this storage is $\$ 4.85 \mathrm{Dth} / \mathrm{d} / \mathrm{month}$. 
The conclusions for the Southeast area are:

- LRC will not compete with firm transportation in Georgia but will in South Carolina and North Carolina. However, connection directly to an end customer or back haul delivery is needed to compete.

- LRC will not compete with LNG for the single cycle of Case 1. However, LRC will compete in Case 2, with a three-cycle operation. This could be of interest for pipeline balancing and power generation. 


\subsection{ENVIRONMENTAL IMPACT AND PERMITTING ISSUES}

\subsection{SUMMARY OF ENVIRONMENTAL IMPACT}

Construction of the LRC facility will last approximately 4-5 years. Conventional techniques will be used to construct tunnels and rooms in the rock; i.e., drill-and-blast. Electrical drilling machines will be used, which implies that new electric cables must be supplied to the working area. There will be minor ground vibrations from the construction. However, the vibration will be very small and contained within approximately 200 meters (650 feet) from the construction area.

Some of the rock mass can be used for site preparation in connection with the facility and in production of concrete for the storage. Remaining rock aggregate will be piled or sold on the market. Traffic will mainly occur in connection with disposal of crusher material. The rock aggregate used for construction purposes may be crushed in a mobile crusher near the pile. The total amount of rock aggregate from the excavation will be approximately $600,000 \mathrm{~m}^{2}$ (21 million cubic feet) for a four-cavern facility.

In this chapter of the report, a very brief summary of the potential environmental impacts (both during and after construction) is provided.

\subsubsection{Environmental Effects During the Construction Period}

Effects on the environment during the construction of the plant can be divided into two main categories: (1) influence from rock excavation work and (2) influence from construction of the connecting pipeline. Pipeline connection is a well-known technology, and is, therefore, not discussed here.

\section{Landscape}

The landscape will be influenced from establishing the working site and construction of the plant. Trailers for workers, warehouse, and workshop will be placed at the tunnel entrance. Areas for parking and arrangements for trailers will be made adjacent to the entrance.

Rock aggregate that is placed permanently or temporarily can affect the landscape. Vegetation in the rock aggregate area has to be cut. Access roads will also be developed.

\section{Ground}

Within the working area for the storage, there will be an impact on soil because of the traffic. There will be effects on the forestry in the area that is affected by the workings. 
Certain work near the working site will be limited. The damage incurred is estimated to be moderate and restoration will be done after the construction is finished.

\section{Vegetation}

No affect is assumed on the vegetation due to eventual lowering of the water table in the area. Other damages to the vegetation are estimated only to be in the areas of the buildings and the tunnel entrance.

\section{Animals}

The animals in the area may be disturbed by the construction. After some work progress, the rock excavating will be done at greater depths and the disturbance on the ground will be minimized. Other work on the ground may also disturb the animal life, but this disturbance is expected to be very low.

\section{Groundwater}

An eventually lower water table will be very local and presumably will only exist for a very short time. Eventually, a well very near the working site could be influenced by a lower water table. However, this is estimated only to occur for short periods of time.

The technique of constructing the storage cavern is based on limiting the inflowing water in the tunnel system. This will be done by grouting; i.e., injection of a cement slurry in the rock cracks.

The water that is still leaking into the tunnel system and cavern room will be pumped up to the ground and be cleaned. Some water will be reused in the building process and some will be disposed. As an alternative, the water can be injected back into the ground.

\section{Watercourses and wetlands}

A very small influence is expected on watercourses and wetlands in the area.

\section{Recreation}

Recreation in the area around the working site may be disturbed because of the noise from work at the plant and from the traffic. This is expected to be contained within 200-500 meters (650-1,640 feet), depending on the site topography. At large distances, the influence will be small. Certain restrictions can be put in place concerning trespass on ground areas near the working site.

\section{Noise and vibration on the ground}

It is a matter of course that a construction site of this size will generate noise. This noise is caused by excavation, transportation, and the ventilation plant for the tunnel. Disturbing noise 
levels from the excavation will only be present during the first 3-4 weeks. After this, the excavation will have gone so far into the rock that almost no noise can be heard on the ground.

\section{Dust}

Dust arises in connection with vehicular travel. The amount of dust from vehicles should be very small, depending on the condition of the roads. Dust from excavation near the ground is limited in both time and space.

\section{Discharge}

The risk of discharge in the surroundings is regarded as small. A source of discharge that can be identified is from the vehicles that are used at the site. Exhaust from these vehicles can, however, be cleaned effectively. Eventual discharge of oil will be limited by demands on the contractor.

\subsubsection{Environmental Effects After the Construction Period}

\section{Landscape}

The plant will have three to four smaller buildings that will be built within an area that will be fenced. A small parking space will be built in connection with the aboveground plant. Existing vegetation and trees shall, as far as possible, be left to minimize the impact on the landscape.

\section{Ground}

The use of ground for forestry and farming will be influenced in the area where the aboveground plant is situated. The aboveground plant will be fenced.

\section{Animals}

Noise from compressors may disturb sensitive animal life. However, this is not different from existing storage alternatives.

\section{Groundwater}

An eventually lower level of groundwater around the storage will be very local and limited during a very short time.

The technique of constructing the storage is based on limiting the inflowing water in the tunnel system. This will be done by grouting; i.e., injection of cement slurry in the rock cracks. The rock mass can be expected to be very dense and no large problems with groundwater loss is expected. 


\section{Watercourses and wetlands}

A very small influence is expected on watercourses and wetlands.

\section{Recreation}

There will be local noise from compressors. Area for the aboveground plant will be fenced. However, this is no different from existing storage alternatives.

\section{Cultural environment}

No influence is expected.

\section{Noise}

There will be noise from the compressor station. The compressors will be isolated to minimize the noise.

\section{Dust}

Dust will practically not exist.

\section{Emission}

Emission of natural gas will only occur during maintenance of the aboveground facilities or in an emergency situation.

\subsection{PERMIT SUMMARY}

Tables 8-1 and 8-2 identify the federal and state regulations (Massachusetts and Georgia) that are or may be applicable to the LRC technology. Regulations and permits required in each state are principally driven by federal legislation, and are, therefore, generally similar.

A column is included in both tables that is entitled "Relevance to LRC Technology." This column indicates whether a specific permit is required, likely to be required, or unlikely to be required. Many of the permit requirements are site specific. It is, therefore, important to consider all potential permit requirements in the site selection and design phases of the work.

Factors which will affect the permitting schedule and cost for an LRC storage facility in each state are highly site specific and should be an important consideration during the site selection process. For example, locating an LRC facility near a valuable and protected resource, such as a wild and scenic river, will result in an increase in the time required and cost for permitting. In addition, a river basin commission authorization may also be required based on the proposed location of the LRC facility and the potential impacts of dewatering operations on area groundwater. 
Table 8-1. Federal and State Regulations That are or may be Applicable to the LRC Technology in Massachusetts (Page 1 of 5)

\begin{tabular}{|c|c|c|c|c|}
\hline Type & Citation & Agency & Description and Requirements & $\begin{array}{c}\text { Relevance } \\
\text { to LRC } \\
\text { Tech. }\end{array}$ \\
\hline & $\begin{array}{l}18 \text { CFR Part } \\
157 \& 284^{\text {(a) }}\end{array}$ & FERC & $\begin{array}{l}\quad \text { 7(C) Certificates of the Natural Gas Act } \\
\text { Certificates are required to demonstrate or receive: } \\
\text { - public convenience and necessity } \\
\text { - provision of storage and transportation services } \\
\text { - approval of market-based rates } \\
\text { - confidential treatment } \\
\text { Typical permit application requirements include the } \\
\text { following descriptions or evaluations: } \\
\text { - project } \\
\text { - water use \& quality } \\
\text { - vegetation \& wildlife } \\
\text { - cultural resources } \\
\text { - socioeconomics } \\
\text { - geology } \\
\text { - soils } \\
\text { - land use, recreation, and aesthetics } \\
\text { - air \& noise quality } \\
\text { - alternatives } \\
\text { - engineering design. }\end{array}$ & Yes \\
\hline $\begin{array}{l}\text { Regulatory } \\
\text { Affairs }\end{array}$ & $\begin{array}{l}301 \mathrm{CMR} \\
11.00^{(\mathrm{b})}\end{array}$ & $\begin{array}{l}\text { MEPA } \\
\text { (State) }\end{array}$ & $\begin{array}{l}\text { Massachusetts Environmental Policy Act } \\
\text { Environmental Notification Form (ENF) to be filed } \\
\text { with the Massachusetts Environmental Policy Act } \\
\text { (MEPA) Office. } \\
\text { Agency and public comment period follow. } \\
\text { Environmental Impact Report (EIR) may be required. } \\
\text { Agency and public comment periods follow with a } \\
\text { statement issued at the end of the process. }\end{array}$ & $\begin{array}{c}\text { Likely } \\
\text { Unlikely }\end{array}$ \\
\hline $\begin{array}{l}\text { Air Quality } \\
\text { Control }\end{array}$ & $\begin{array}{l}310 \mathrm{CMR} \\
6.00,7.00, \& \\
8.00\end{array}$ & $\begin{array}{l}\text { MADEP } \\
\text { (State) }\end{array}$ & $\begin{array}{l}\qquad \underline{\text { Air Permits }} \\
\text { Air Plan approval required for construction of certain } \\
\text { projects: } \\
\text { - fuel utilization facility with energy input above } \\
\text { certain threshold limits } \\
\text { - construction in nonattainment areas } \\
\text { - certain boilers, stationary engines, \& emergency } \\
\text { generators. } \\
\text { Relevant Permits: } \\
\text { BWP AQ 02 (Nonmajor comprehensive approval) } \\
\text { BWP AQ 03 (Major comprehensive approval) }\end{array}$ & $\begin{array}{l}\text { Likely } \\
\text { Unlikely }\end{array}$ \\
\hline
\end{tabular}


Table 8-1. Federal and State Regulations That are or may be Applicable to the LRC Technology in Massachusetts (Page 2 of 5)

\begin{tabular}{|c|c|c|c|c|}
\hline Type & Citation & Agency & Description and Requirements & $\begin{array}{c}\text { Relevance } \\
\text { to LRC } \\
\text { Tech. }\end{array}$ \\
\hline $\begin{array}{l}\text { Industrial } \\
\text { Wastewater } \\
\text { Management }\end{array}$ & $\begin{array}{l}314 \text { CMR } \\
\text { 314 CMR } \\
3,00,4.00 \& \\
12.00 \\
314 \mathrm{CMR} \\
7.00 \& 12.00 \\
\\
314 \mathrm{CMR} \\
5.00 \& 6.00 \\
314 \mathrm{CMR} \\
12.00\end{array}$ & $\begin{array}{l}\text { MADEP } \\
\text { (State) }\end{array}$ & $\begin{array}{l}\text { NPDES Permits - Industrial Wastewater } \\
\text { BWP IW 18 Permit required for industrial wastewater } \\
\text { discharge to surface waters (no threshold limits based } \\
\text { on discharge volume or rate). } \\
\text { BWP IW 12 (Type I Facility) Permit and Plan approval } \\
\text { required for industrial wastewater discharge to MA } \\
\text { sewer system. } \\
\text { BWP IW } 24 \text { (Type I Facility) - plan approval only. } \\
\text { BWP IW 05 (Type I Facility) Permit to discharge } \\
\text { industrial wastewater to groundwater. } \\
\text { Permits required to store industrial wastewater on site } \\
\text { in a holding tank with disposal via POTW. No } \\
\text { thresholds based on amount of discharge. } \\
\text { BWP IW 01 (Permit to construct \& install a non- } \\
\text { hazardous holding tank). } \\
\text { BWP IW 28 (Permit to convert an existing tank to a } \\
\text { nonhazardous holding tank). }\end{array}$ & $\begin{array}{l}\text { Possible } \\
\text { Unlikely }\end{array}$ \\
\hline $\begin{array}{l}\text { Water } \\
\text { Pollution } \\
\text { Control }\end{array}$ & $\begin{array}{l}310 \text { CMR } \\
15.00 \text { (Title } 5 \\
\text { Regulations) } \\
\\
314 \text { CMR } \\
7.00 \& 12.00\end{array}$ & $\begin{array}{l}\text { Municipal } \\
\text { Board of } \\
\text { Health }\end{array}$ & 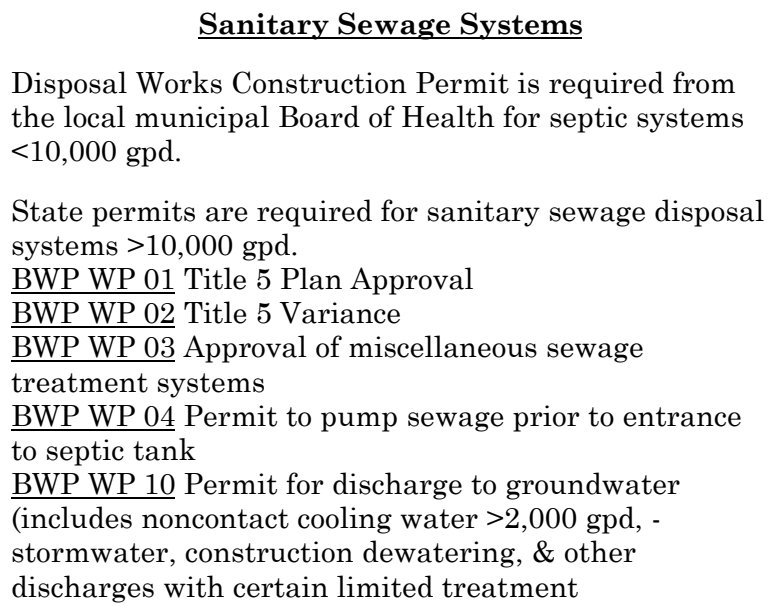 & Unlikely \\
\hline
\end{tabular}


Table 8-1. Federal and State Regulations That are or may be Applicable to the LRC Technology in Massachusetts (Page 3 of 5)

\begin{tabular}{|c|c|c|c|c|}
\hline Type & Citation & Agency & Description and Requirements & $\begin{array}{c}\text { Relevance } \\
\text { to LRC } \\
\text { Tech. }\end{array}$ \\
\hline $\begin{array}{l}\text { Water } \\
\text { Pollution } \\
\text { Control }\end{array}$ & $\begin{array}{l}314 \mathrm{CMR} \\
7.00 \& 12.00 \\
\\
314 \mathrm{CMR} \\
7.00 \& 12.00\end{array}$ & $\begin{array}{l}\text { MADEP } \\
\text { (State) }\end{array}$ & $\begin{array}{l}\text { Sewer Connection to Public System } \\
\text { Permits are required for the following public sewer } \\
\text { connections. } \\
\text { BRP WP 14 Sewer extension } \leq 2,500 \text { feet \& with flows } \\
<50,000 \text { gpd or connected to a pump station. } \\
\text { BRP WP 55 Permit for sewer extension or industrial } \\
\text { wastewater connection (not covered under Industrial } \\
\text { Wastewater Management Program) for flows } \geq 15,000 \\
\text { gpd. } \\
\quad \text { Industrial Wastewater Holding Tank } \\
\text { BRP WP } 56 \text { Permit for industrial wastewater holding } \\
\text { tank for a facility without a safer alternative. }\end{array}$ & $\begin{array}{l}\text { Possible } \\
\text { Unlikely }\end{array}$ \\
\hline $\begin{array}{l}\text { Watershed } \\
\text { Management }\end{array}$ & $\begin{array}{l}40 \mathrm{CFR} \\
122-125 \\
31 \mathrm{CMR} \\
3.00 \& 4.00\end{array}$ & $\begin{array}{l}\text { USEPA \& } \\
\text { MADEP } \\
\text { (State) }\end{array}$ & $\begin{array}{l}\text { NPDES Permits - Surface Water Discharge } \\
\text { NOTE: Massachusetts is not a delegated state under } \\
\text { the Clean Water Act; therefore, a USEPA General } \\
\text { Permit is required for Stormwater (Notice of Intent), } \\
\text { construction site dewatering, noncontact cooling water, } \\
\text { \& minor nonprocess wastewater. An approved storm } \\
\text { water management plan is required. MADEP review } \\
\text { will not being until after a draft permit has been } \\
\text { received from USEPA. The permit program is } \\
\text { administered jointly with the USEPA. } \\
\text { BWP WM 06 (Type I Surface Water Discharge). } \\
\text { BWP WM 08 (EPA General Permit (NOI), Stormwater). } \\
\text { BWP WM 09 (Approval of Stormwater Management } \\
\text { Plan). } \\
\text { BWP WM } 10 \text { (EPA General Permit, Construction Site } \\
\text { Dewatering). } \\
\text { BWP WM 11 (EPA General Permit, Noncontact Cooling } \\
\text { Water). } \\
\text { BWP WM } 13 \text { (EPA General Permit, Minor Nonprocess } \\
\text { Wastewater). }\end{array}$ & $\begin{array}{l}\text { Unlikely } \\
\text { Yes } \\
\text { Yes } \\
\text { Yes } \\
\text { Unlikely } \\
\text { Possible }\end{array}$ \\
\hline $\begin{array}{l}\text { Watershed } \\
\text { Management }\end{array}$ & $\begin{array}{l}310 \mathrm{CMR} \\
4.00 \& 36.00\end{array}$ & $\begin{array}{l}\text { MADEP } \\
\text { (State }\end{array}$ & $\begin{array}{l}\text { Surface Water \& Groundwater Withdrawal } \\
\text { BRP WM 03 Permit required for surface water or } \\
\text { groundwater withdrawal from river basins at a rate } \\
>100,000 \text { gpd or }>9 \text { million gal } / 3 \text { mos. }\end{array}$ & Unlikely \\
\hline
\end{tabular}


Table 8-1. Federal and State Regulations That are or may be Applicable to the LRC Technology in Massachusetts (Page 4 of 5)

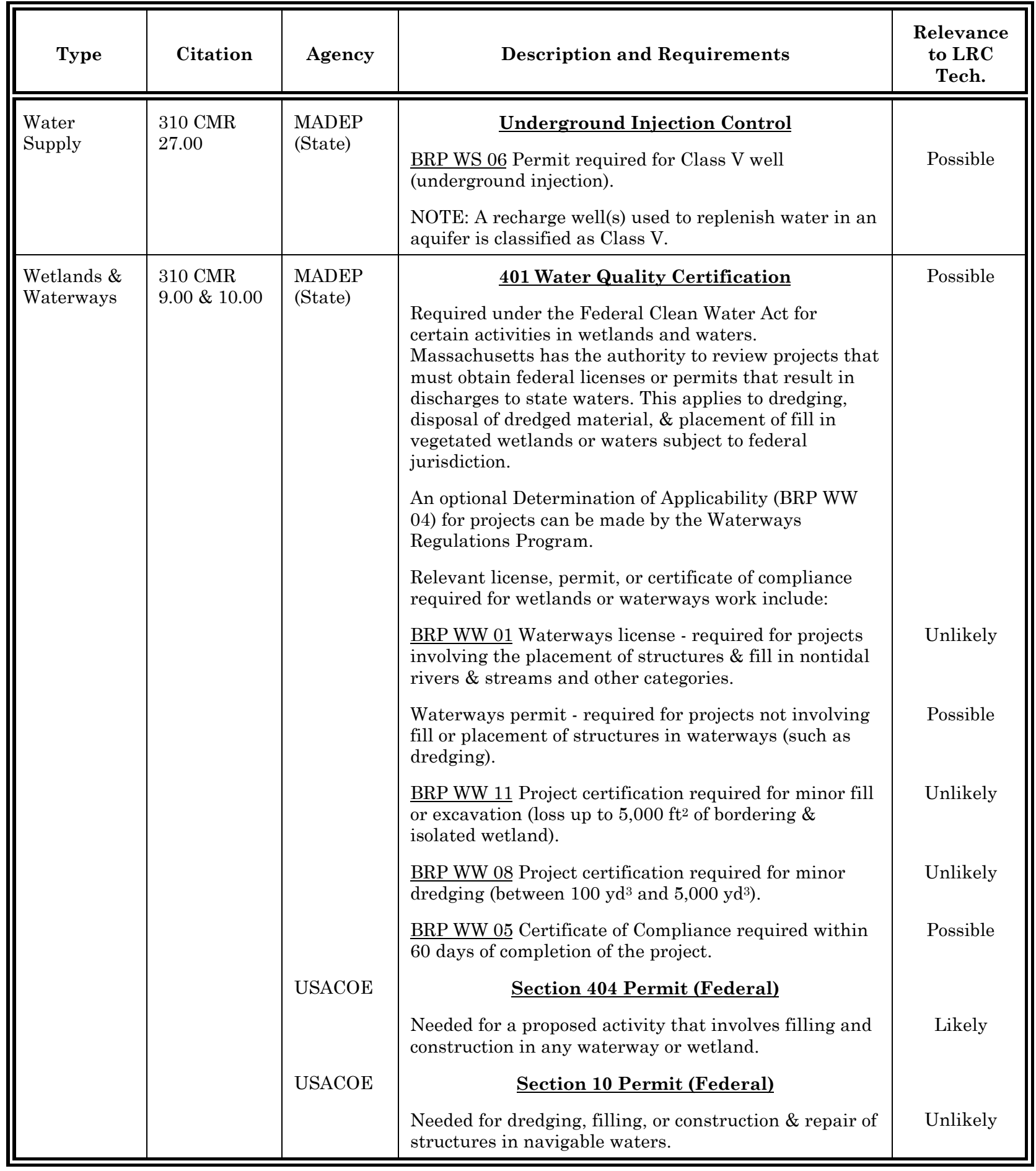


Table 8-1. Federal and State Regulations That are or may be Applicable to the LRC Technology in Massachusetts (Page 5 of 5)

\begin{tabular}{|c|c|c|c|c|}
\hline Type & Citation & Agency & Description and Requirements & $\begin{array}{l}\text { Relevance } \\
\text { to LRC } \\
\text { Tech. }\end{array}$ \\
\hline $\begin{array}{l}\text { Wetlands \& } \\
\text { Waterways }\end{array}$ & $\begin{array}{l}310 \mathrm{CMR} \\
10.00\end{array}$ & $\begin{array}{l}\text { Local } \\
\text { Conservation } \\
\text { Commission }\end{array}$ & $\begin{array}{l}\qquad \text { Wetlands Protection } \\
\text { Wetlands protection is administered by local } \\
\text { conservation commissions. } \\
\text { A Notice of Intent (NOI) and permit (Order of } \\
\text { Conditions) is required from the local conservation } \\
\text { commission for removing, dredging, filling, or other } \\
\text { altering of a wetland. }\end{array}$ & Possible \\
\hline $\begin{array}{l}\text { Hazardous } \\
\text { Materials }\end{array}$ & $\begin{array}{l}40 \text { CFR } 262 \\
310 \text { CMR } \\
30.00\end{array}$ & $\begin{array}{l}\text { USEPA } \\
\text { MADEP } \\
\text { (State) }\end{array}$ & $\begin{array}{l}\qquad \text { Hazardous Waste Generators } \\
\text { Registration required for hazardous waste generators } \\
\text { (LQG, SQG, \& VSQG). } \\
\text { - EPA ID Number required for LQG \& SQG (except } \\
\text { waste oil) } \\
\text { - MADEP registration required for VSQG \& waste oil } \\
\text { SQG. } \\
\text { NOTE: Waste oil is classified as hazardous in MA. } \\
\text { Hazardous materials recycling permit required for }>27 \\
\text { gal. hazardous waste per month. }\end{array}$ & Possible \\
\hline $\begin{array}{l}\text { Toxics Use } \\
\text { Reporting }\end{array}$ & $\begin{array}{l}310 \mathrm{CMR} \\
40.00 \\
41.00, \& \\
50.00\end{array}$ & $\begin{array}{l}\text { MADEP } \\
\text { (State) }\end{array}$ & $\begin{array}{l}\text { Regulations which apply to facilities that use at least } \\
10,000 \text { lbs. of any chemical listed on EPA's Toxic } \\
\text { Release Inventory (Section } 313 \text { - Emergency Planning } \\
\text { and Right-to-Know and CERCLA). }\end{array}$ & Unlikely \\
\hline $\begin{array}{l}\text { Solid Waste } \\
\text { Management }\end{array}$ & $\begin{array}{l}310 \mathrm{CMR} \\
16.00 \& \\
19.00\end{array}$ & $\begin{array}{l}\text { MADEP } \\
\text { (State) }\end{array}$ & $\begin{array}{l}\text { Solid Waste Management Facilities } \\
\text { NOTE: A comprehensive site assessment is required } \\
\text { for a solid waste management facility permit. } \\
\text { Permits (or other) are required for the following } \\
\text { categories: } \\
\text { BWP SW } 17 \text { Determination of Need, Small Operation } \\
\text { Site Assignment. } \\
\text { BWP SW } 27 \text { Permit for new landfill between } 25 \& 250 \\
\text { acre feet (volume). } \\
\text { BWP SW } 28 \text { Permit for new landfill <25 acre feet } \\
\text { BWP SW } 10 \text { Permit to receive authorization to operate } \\
\text { a new landfill. } \\
\text { BWP SW 01 Permit to establish a new solid waste } \\
\text { facility. }\end{array}$ & Unlikely \\
\hline
\end{tabular}

(a) Code of Federal Regulations.

(b) Code of Massachusetts Regulations. 
Table 8-2. Federal and State Regulations That are or may be Applicable to the LRC Technology in Georgia (Page 1 of 4)

\begin{tabular}{|c|c|c|c|c|}
\hline Type & Citation & Agency & Description and Requirements & $\begin{array}{c}\text { Relevance } \\
\text { to LRC } \\
\text { Tech. }\end{array}$ \\
\hline & $\begin{array}{l}18 \text { CFR Part } \\
157 \& 284^{(a)}\end{array}$ & FERC & $\begin{array}{l}\quad \text { 7(C) Certificates of the Natural Gas Act } \\
\text { Certificates are required to demonstrate or receive: } \\
\text { - public convenience and necessity } \\
\text { - provision of storage and transportation services } \\
\text { - approval of market-based rates } \\
\text { - confidential treatment } \\
\text { Typical permit application requirements include the } \\
\text { following descriptions or evaluations: } \\
\text { - project } \\
\text { - water use \& quality } \\
\text { - vegetation \& wildlife } \\
\text { - cultural resources } \\
\text { - socioeconomics } \\
\text { - geology } \\
\text { - soils } \\
\text { - land use, recreation, and aesthetics } \\
\text { - air \& noise quality } \\
\text { - alternatives } \\
\text { - reliability \& safety } \\
\text { - engineering design. }\end{array}$ & Yes \\
\hline $\begin{array}{l}\text { Underground } \\
\text { Storage }\end{array}$ & $\begin{array}{l}\text { OCGA } \\
\text { Section 46-4- } \\
50 \text { to } 46-4-62\end{array}$ & $\begin{array}{l}\text { GA Public } \\
\text { Service } \\
\text { Comm. } \\
\text { (State) }\end{array}$ & $\begin{array}{l}\text { Underground Gas Storage } \\
\text { Requirements \& regulations which apply to utilities } \\
\text { desiring to use or operate an underground reservoir. An } \\
\text { order approving the project is required from the Public } \\
\text { Service Commission. } \\
\text { - The application shall include a legal description of all } \\
\text { proposed improvements, maps showing the proposed } \\
\text { facilities and underground reservoir, and other } \\
\text { information to provide a clear and concise } \\
\text { presentation. }\end{array}$ & Yes \\
\hline $\begin{array}{l}\text { Surface } \\
\text { Mining }\end{array}$ & $\begin{array}{l}\text { Chapter 390- } \\
3-3^{\text {(b) }} \text {, } \\
\text { Surface } \\
\text { Mining }\end{array}$ & $\begin{array}{l}\text { GDNR } \\
\text { (EPD) } \\
\text { (State) }\end{array}$ & $\begin{array}{l}\qquad \text { Surface Mining } \\
\text { Permit and Mine Land Use Plan required for surface } \\
\text { mining. The Mine Land Use Plan shall include: } \\
\text { - Engineering drawings, plans, specifications, maps, or } \\
\text { other attachments } \\
\text { - A specific plan of action } \\
\text { - Description of the company } \\
\text { - Mining methods \& lands to be affected } \\
\text { - Reclamation objective \& schedule } \\
\text { - Affected acreage } \\
\text { - Protection of contiguous natural resources \& } \\
\text { - } \text { Eroperty on the National Register of Historic Places } \\
\text { Erosion \& siltation control. }\end{array}$ & Likely \\
\hline
\end{tabular}


Table 8-2. Federal and State Regulations That are or may be Applicable to the LRC Technology in Georgia (Page 2 of 4)

\begin{tabular}{|c|c|c|c|c|}
\hline Type & Citation & Agency & Description and Requirements & $\begin{array}{l}\text { Relevance } \\
\text { to LRC } \\
\text { Tech. }\end{array}$ \\
\hline $\begin{array}{l}\text { Eminent } \\
\text { Domain }\end{array}$ & $\begin{array}{l}\text { Chapter 391- } \\
3-23, \\
\text { Petroleum } \\
\text { Pipeline } \\
\text { Eminent } \\
\text { Domain } \\
\text { Procedures }\end{array}$ & $\begin{array}{l}\text { GDNR } \\
\text { (EPD) } \\
\text { (State) }\end{array}$ & $\begin{array}{l}\quad \text { Petroleum Pipeline Eminent Domain } \\
\text { A Certificate of Public Convenience and Necessity is } \\
\text { needed from the Commissioner followed by a permit. } \\
\text { Permit application requirements include: } \\
\text { - Certificate of Public Convenience } \\
\text { - Property information (inc. consultations with owners) } \\
\text { - Environmental effects report } \\
\text { - Background engineering reports. }\end{array}$ & Possible \\
\hline Air & $\begin{array}{l}\text { Chapter 391- } \\
\text { 3-1, Air } \\
\text { Quality } \\
\text { Control }\end{array}$ & $\begin{array}{l}\text { GDNR } \\
\text { (EPD) } \\
\text { (State) }\end{array}$ & $\begin{array}{l}\qquad \underline{\text { Air Permits }} \\
\text { Title V Program Permit, application requirements } \\
\text { include: } \\
\text { - Facility-wide information } \\
\text { - Emission unit information } \\
\text { - Emissions data } \\
\text { - Monitoring program } \\
\text { - Compliance program (for existing facilities not in } \\
\text { - compliance) } \\
\text { NOccidental release prevention program. } \\
\text { emissions units. }\end{array}$ & Likely \\
\hline \multirow[t]{4}{*}{ Water } & \multirow[t]{4}{*}{$\begin{array}{l}\text { Chapter 391- } \\
3-16.03 \\
\text { Federal } \\
\text { Water } \\
\text { Pollution } \\
\text { Control Act, } \\
\text { Sections 301- } \\
303,306 \text { \& } \\
307\end{array}$} & $\begin{array}{l}\text { GDNR } \\
\text { (EPD) } \\
\text { (State) }\end{array}$ & $\begin{array}{l}\qquad \frac{\text { Joint Application }}{401 \text { Certification of Water Quality }} \\
\text { State program is coordinated with USACOE (Savanna } \\
\text { Dist.) via a Memorandum of Understanding. Federal } \\
\text { Water Pollution Control permits through USACOE are } \\
\text { typically included. }\end{array}$ & Likely \\
\hline & & $\begin{array}{l}\text { USACOE } \\
\text { (Federal) }\end{array}$ & $\begin{array}{l}\text { Section } 404 \text { Permit (Federal) } \\
\text { Needed for a proposed activity that involves filling and } \\
\text { construction in any waterway or wetland. }\end{array}$ & Likely \\
\hline & & & Section 10 Permit (Federal) & Unlikely \\
\hline & & $\begin{array}{l}\text { USACOE } \\
\text { (Federal) }\end{array}$ & $\begin{array}{l}\text { Needed for dredging, filling, or construction of } \\
\text { structures in navigable waters. }\end{array}$ & \\
\hline
\end{tabular}


Table 8-2. Federal and State Regulations That are or may be Applicable to the LRC Technology in Georgia (Page 3 of 4)

\begin{tabular}{|c|c|c|c|c|}
\hline Type & Citation & Agency & Description and Requirements & $\begin{array}{c}\text { Relevance } \\
\text { to LRC } \\
\text { Tech. }\end{array}$ \\
\hline Water & $\begin{array}{l}\text { Chapter 391- } \\
\text { 3-6, Water } \\
\text { Quality } \\
\text { Control }\end{array}$ & $\begin{array}{l}\text { GDNR } \\
\text { (EPD) } \\
\text { (State) }\end{array}$ & $\begin{array}{l}\qquad \text { NPDES Permitting } \\
\text { Authority delegated to state by USEPA. } \\
\text { State regulations pursuant to the GA Water Quality } \\
\text { Control Act. NPDES permits are required for the } \\
\text { following categories: } \\
\text { - Storm water associated with industrial activity } \\
\text { - Nonstorm water (general or individual) } \\
\text { - Storm water associated with construction } \\
\text { - Underground Injection Control } \\
\text { - Land disposal \& treatment systems } \\
\text { - Land application facilities. } \\
\text { Permit application requirements include: } \\
\text { Storm Water (industrial activity) Notice of Intent, } \\
\text { pollution prevention plant, engineering report(s), plans } \\
\text { \& specifications, monitoring program, notice \& public } \\
\text { participation. } \\
\text { Storm Water (construction) } \\
\text { Nonstorm Water Notice of Intent, engineering } \\
\text { report(s), plans, specifications \& related materials, } \\
\text { notice \& public participation. }\end{array}$ & $\begin{array}{l}\text { Likely } \\
\text { Yes } \\
\text { Possible }\end{array}$ \\
\hline Groundwater & $\begin{array}{l}\text { Chapter 391- } \\
3-2 \text {, } \\
\text { Groundwater } \\
\text { Use }\end{array}$ & $\begin{array}{l}\text { GDNR } \\
\text { (EPD) } \\
\text { (State) }\end{array}$ & $\begin{array}{l}\text { Groundwater Withdrawal } \\
\text { The state regulates groundwater withdrawal and/or use } \\
\text { at rate of }>100,000 \text { gpd. A permit is required for } \\
\text { consumptive or nonconsumptive use. Permit } \\
\text { requirements include: } \\
\text { - State concurrent on well construction } \\
\text { - Documentation } \\
\text { - Proposed groundwater injection well information } \\
\text { - Aquifer characteristics } \\
\text { - Drilling \& well construction information. }\end{array}$ & Unlikely \\
\hline $\begin{array}{l}\text { Hazardous } \\
\text { Waste }\end{array}$ & $\begin{array}{l}\text { Chapter 391- } \\
3-11 \text {, Solid } \\
\text { Waste } \\
\text { Management } \\
40 \text { CFR } 262\end{array}$ & $\begin{array}{l}\text { GDNR } \\
\text { (EPD) } \\
\text { (State) } \\
\text { USEPA }\end{array}$ & $\begin{array}{l}\qquad \text { Hazardous Waste Generators } \\
\text { Registration, storage, handling, shipping, and } \\
\text { treatment/disposal requirements for hazardous waste } \\
\text { generators (LQG \& SQG). } \\
\text { - EPA ID Number required for LQG \& SQG } \\
\text { generators. }\end{array}$ & Possible \\
\hline
\end{tabular}


Table 8-2. Federal and State Regulations That are or may be Applicable to the LRC Technology in Georgia (Page 4 of 4)

\begin{tabular}{|c|c|c|c|c|}
\hline Type & Citation & Agency & Description and Requirements & $\begin{array}{l}\text { Relevance } \\
\text { to LRC } \\
\text { Tech. }\end{array}$ \\
\hline $\begin{array}{l}\text { Solid Waste } \\
\text { Management }\end{array}$ & $\begin{array}{l}\text { Chapter 391- } \\
3-4 \text {, Solid } \\
\text { Waste } \\
\text { Management }\end{array}$ & $\begin{array}{l}\text { GDNR } \\
\text { (EPD) } \\
\text { (State) }\end{array}$ & $\begin{array}{l}\quad \text { Solid Waste Management Landfills } \\
\text { Permit required for construction \& operation of a solid } \\
\text { waste landfill. Landfill siting requirements include: } \\
\text { - Site assessment report geologic, hydrologic, \& env. } \\
\text { resources) } \\
\text { - Application of specific design criteria } \\
\text { - Approved monitoring program } \\
\text { - Closure requirements. }\end{array}$ & Unlikely \\
\hline $\begin{array}{l}\text { Underground } \\
\text { Storage Tank } \\
\text { Management }\end{array}$ & $\begin{array}{l}\text { Chapter 391- } \\
3-15 \text {, } \\
\text { Underground } \\
\text { Storage } \\
\text { Tank } \\
\text { Management }\end{array}$ & $\begin{array}{l}\text { GDNR } \\
(\mathrm{EPD}) \\
\text { (State) }\end{array}$ & $\begin{array}{l}\text { Underground Storage Tank Registration } \\
\text { Annual registration required for underground storage } \\
\text { tanks. }\end{array}$ & Possible \\
\hline
\end{tabular}

(a) Code of Federal Regulations.

(b) Rules of the Georgia Department of Natural Resources, Environmental Protection Division.

Overall, a rough estimate of the time required to obtain necessary permits in these states will generally range between 18 and 24 months, based on the following assumptions:

- An Environmental Impact Statement (EIS) is not required (site location is critical for this issue).

- Site selection, property acquisition (excluding pipeline right-of-ways, if required), and preliminary design are substantially complete at the onset of permit studies and applications.

It should be further noted that the following issues may increase the permitting schedule:

- If the project is opposed by the agencies, special interest groups, or intervenors.

- Construction and/or project health and safety reviews, as may be required by the Occupational Safety and Health Administration (OSHA) or Mine Safety and Health Administration (MSHA) may be required.

- Local municipal reviews and approvals will be required.

As far as costs for licensing and permitting, project specifics, such as length of pipeline tieins, proximity to environmentally sensitive areas, and level of opposition to the project, greatly impact the costs of permitting and licensing. Therefore, a range of $\$ 2-10$ million for permitting activities would not be unreasonable. 


\subsection{REFERENCES}

Barton, N., R. Lien, and J. Lunde, 1974. "Engineering Classification of Rock Masses for the Design of Tunnel Support," Rock Mechanics, Springer Verlag, Vol. 6, pp. 189-236.

Bieniawski, Z. T., 1973. "Engineering Classification of Jointed Rock Masses," Trans. South African Inst. Civ. Eng., Vol. 15, No. 12, pp. 335-344.

Bieniawski, Z. T., 1978. "Determining Rock Mass Deformability - Experiences From Case Histories," International Journal of Rock Mechanics and Mining Science \& Geomechanics Abstracts, Vol. 15, pp. 237-247.

Brown, E. T., J. W. Bray, B. Ladanyi, and E. Hoek, 1983. "Ground Response Curves for Rock Tunnels," Journal of Geotechnical Engineering, ASCE 109, pp. 15-39.

Energy and Environmental Inc., 1994. Cost of New Underground Natural Gas Storage Facilities in the Lower 48 States, final report submitted to United States Department of Energy and the Energy Information Administration.

Energy Information Administration, 1998. Natural Gas 1998: Issues and Trends.

Goldsmith, R., 1987. The Bedrock Geology of Massachusetts, U.S. Geologic Survey Professional Paper 1366-E-J.

Grimstad, E. and E. Barton, 1993. "Updating of the Q-System for NMT," Proceedings, International Symposium on Sprayed Concrete - Modern Use of Wet Mixed Sprayed Concrete for Underground Support, Fagernes, Eds. Kompen Opsahl och Berg. Norwegian Concrete Association, Oslo, Norway.

Harvey, R. C. and E. Burley, 1973. "Behaviour of Shallow Inclined Anchorages in Cohesionless Sand," Ground Engineering, Vol. 6, pp. 48-55.

Hoek, E., and E. T. Brown, 1980. "Underground Excavations in Rock," Institute of Mining and Metallurgy, London.

Hoek, E., P. K. Kaiser, and W. F. Bawden, 1997. Support of Underground Excavations in Hard Rock, A. A. Balkema.

Isander, A., 1994. "Rock Mechanical Results From a Research Facility for Storage of Natural Gas in Lined Rock Caverns," ISRM International Symposium, Santiago, Chile. 
Littlejohn, G. S. and D. A. Bruce, 1975. "Rock Anchors - State of the Art," Ground Engineering, May.

McConnell, K. I. and J. O. Costello, 1982. "Guide to Geology Along a Traverse Through the Blue Ridge and Piedmont Provinces of North Georgia," Excursions in Southeastern Geology, R. W. Frey (ed.), American Geological Institute, Vol. 1, pp. 241-258.

Sagefors, I. and P-A. Daerga, 1996. "An Excavation Method for Large Vertical Cylindrical Caverns," Tunnelling and Underground Space Technology, Vol. 11, No. 3, pp. 279-285.

Serafim, J. L. and J. P. Pereira, J. P., 1983. "Consideration of the Geomechanical Classification of Bieniawski," Proceedings, International Symposium on Engineering Geology and Underground Construction, Lisbon 1(II), pp. 33-44.

Stille, H., 1984. Rock Bolting - Analysis Based on the Theory of Ground Reaction Curve, Report 151:1/84, Swedish Rock Engineering Research, SveBeFo, Stockholm, Sweden.

Stille, H., A. Fredriksson, and T. Groth, 1982. FEM-Analys Av Bergmekaniska Problem Med JOBFEM, BeFo Nr. 307:1/82.

Stille, H., J. Johansson, and R. Sturk, 1994. "High Pressure Storage of Gas in Lined Rock Caverns - Results From Field Tests," Proceedings, EUROCK'94 International Conference, Delft, Balkema, Rotterdam.

Sturk, R. and H. Stille, 1995. "Design and Excavation of Rock Caverns for Fuel Storage - A Case Study From Zimbabwe," Tunneling and Underground Space Technology, Vol. 10, No. 2, pp. 193-201.

Sydgas, 1990a. Catastrophic Case for Lined Rock Caverns, Internal report.

Sydgas, 1990b. Simulation of Natural Gas Dispersion at Leakage From a Rock Storage, Internal report.

Sydgas, 1992. Initial Risk Analysis for Lined Rock Caverns Storage for Natural Gas, Internal report.

Sydgas and Vattenfall, 1992. Swedgas' Storage Project, Technology and Costs, Summary, Internal report.

Sydgas, Sydkraft, Vattenfall, and Swedgas, 1987a. Lined Rock Caverns: Project Carbon Steel Lining, Internal report. 
Sydgas, Avesta Lining, and Swedgas, 1987b. Stainless Steel for Lining of Rock Cavern for Storing of Pressurized Natural Gas, Internal report.

Sydgas, Sydkraft, Avesta Lining, and Vattenfall, 1989. Sydgas Natural Gas Storage Phase 1, Internal report.

Sydkraft and Gas de France, 1996a. Basic Design Report, Internal report.

Sydkraft and Gas de France, 1996b. Final Risk Asssessment, Internal report.

Sydkraft and Gas de France, 1997. Elaboration of Detailed Demonstration Program, Internal report.

Sydkraft and Skanska, 1995a. Authority Standards, Internal report.

Sydkraft and Skanska, 1995b. Operational Conditions, Internal report.

Sydkraft and Skanska, 1995c. Site Specific Conditions, Internal report.

Sydkraft and Skanska, 1995d. Technical Criteria for Localization, Internal report.

Sydkraft and Skanska, 1995e. Risk Analysis, Internal report.

Sydkraft and Skanska, 1995f. Modelling of Sandwich Wall Construction, Internal report.

Sydkraft and Skanska, 1995g. System for Water and Gas Drainage for Lined Gas Storage, Internal report.

Sydkraft and Skanska, 1995h. Supplementary Rock Mechanical Studies, Internal report.

Sydkraft and Skanska, 1995i. Strategy and Program for Quality Assurance, Internal report.

Sydkraft and Skanska, 1995j. Simplified Above Ground Plant, Internal report.

Thompson, J. M., 1997. "U.S. Underground Storage of Natural Gas in 1997: Existing and Proposed," Natural Gas Monthly, September.

Vesic, A. S., 1971. "Breakout Resistance of Objects Embedded in Ocean Bottom," Journal of Soil Mechanics and Foundation Division, ASCE, Vol. 97, No. SM9, pp. 1183-1205. 
APPENDIX A

DESCRIPTION OF JOBFEM

FINITE ELEMENT SOFTWARE 


\section{APPENDIX A \\ DESCRIPTION OF JOBFEM FINITE ELEMENT SOFTWARE}

\section{A FINITE ELEMENT COMPUTER PROGRAM FOR ANALYSIS OF SOIL AND ROCK STRUCTURES}

JOBFEM is a finite element program specially designed to simulate soil and rock structures and offers the following features:

- Material behaviors, such as elasto-plasticity with Mohr-Coulomb failure criteria, multilaminate materials, hyperbolic stress-strain relationship, and a joint model.

- Excavation, filling, variable pore pressure, and temperature loads.

- Calculation of transient and steady state groundwater head or temperature flow.

- Three- and four-node area elements and a four-node joint element.

- The application of support elements such as tensioned and untensioned rock bolts, linings, beams, and shells.

- Analysis of either two-dimensional (plane strain, plane stress) or axisymmetrical problems.

The program system JOBFEM includes a preprocessor for mesh generation and mesh plotting and postprocessors for plotting the results of the analysis in different forms.

JOBFEM was developed at the Department of Soil and Rock Mechanics at the Royal Institute of Technology in Stockholm. The program has been used in Sweden for several years in practical design. A manual in English is available. 


\section{APPENDIX B}

\section{LRC GAS TEMPERATURE CALCULATIONS}




\section{APPENDIX B \\ LRC GAS TEMPERATURE CALCULATIONS}

\section{Temperature and pressure initialization}

During the commissioning procedure, it is planned to pressurize the cavern with water. Therefore, temperature simulations can be initiated with a water-filled cavern. The cavern is assumed to be filled with water for 60 days for the tests. The dewatering phase will last approximately 1 month. The initial conditions are as follows:

Water temperature $\quad 11^{\circ} \mathrm{C}\left(51^{\circ} \mathrm{F}\right)$

Rock temperature $\quad 17^{\circ} \mathrm{C}\left(62^{\circ} \mathrm{F}\right)$

\section{Cavern Characteristics}

The cavern geometric characteristics are as follows:

Midcavern depth $\quad 200 \mathrm{~m}$

Volume $\quad 80000 \mathrm{~m}^{3}$

Diameter $35 \mathrm{~m}$

Height $83 \mathrm{~m}$

3. Thermal characteristics for the surrounding rock mass

The rock thermal properties are as follows:

Conductivity $\quad 3.5 \mathrm{~W} / \mathrm{m} / \mathrm{K}$

Spec. weight $\quad 2,700 \mathrm{~kg} / \mathrm{m}^{3}$

Spec. heat $\quad 800 \mathrm{~J} / \mathrm{kg} / \mathrm{K}$

Geothermal Gradient $\quad 0.03 \mathrm{~K} / \mathrm{m}$

\section{Gas Characteristics}

The thermodynamic functions of the gas are calculated by using norm AGA8.

\section{Cavern performance}

The cavern performance characteristics are as follows:

Working gas

Gas withdrawal, maximum

Gas injection

Time of withdrawal
$14.3 \times 10^{6} \mathrm{~m}^{3}(0.50 \mathrm{Bscf})$

$1.4 \times 10^{6} \mathrm{~m}^{3} /$ day $(50 \mathrm{MMscf} /$ day)

$0.7 \times 10^{6} \mathrm{~m}^{3} /$ day $(25 \mathrm{MMscf} /$ day $)$

$10 \mathrm{~d}$ 
Time of injection $\quad 20 \mathrm{~d}$

Pressure after injection $\quad 230$ bar (3,330 psi)

Pressure after withdrawal 38 bar (550 psi)

Gas injection temperature is equal to $10^{\circ} \mathrm{C}\left(50^{\circ} \mathrm{F}\right)$.

\section{RESULTS}

The results of the thermal simulation are shown in Figure B-1. The first injection starts at Day 11 and lasts for 20 days. After that, there is a quiescence period of 20 days before the 10 -day withdrawal starts. The temperature for this cycle varies from a maximum of $+43^{\circ} \mathrm{C}$ $\left(108^{\circ} \mathrm{F}\right)$ after injection to $-18^{\circ} \mathrm{C}\left(0^{\circ} \mathrm{F}\right)$.

The second injection cycle starts directly after the withdrawal. At the end of the 20-day injection, the cavern temperature is $37^{\circ} \mathrm{C}\left(99^{\circ} \mathrm{F}\right)$. The preceding 10-day withdrawal starts immediately after the injection. The temperature after withdrawal is $-18^{\circ} \mathrm{C}\left(0^{\circ} \mathrm{F}\right)$. The cycle is repeated again with the same results. 


\section{Pressure and temperature variation in the cavern}

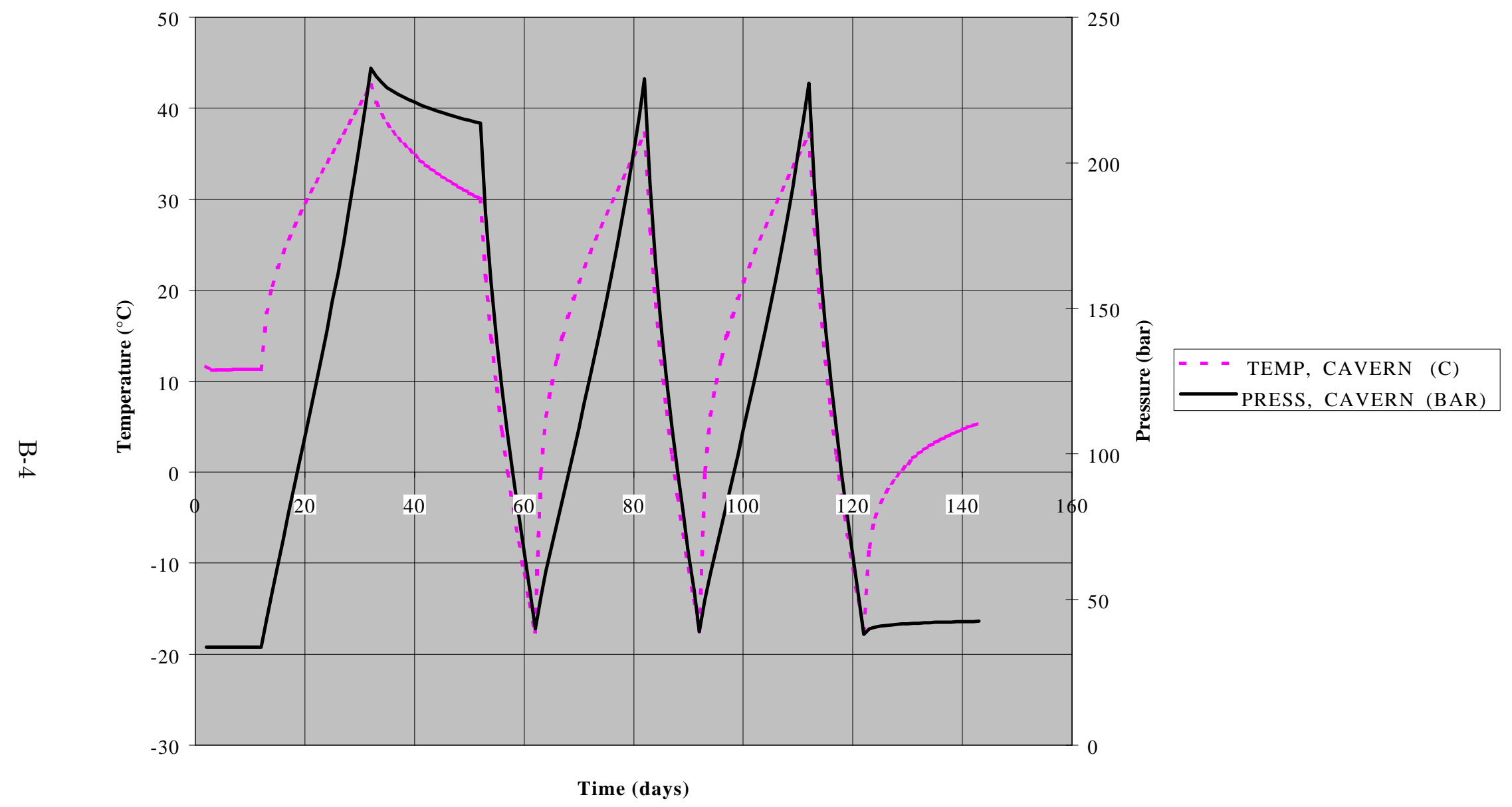

Figure B-1. Pressure and Temperature Variation in the Cavern. 


\section{APPENDIX C}

\section{DESIGN DRAWINGS}




\section{APPENDIX C \\ DESIGN DRAWINGS}

\begin{tabular}{|c|c|c|c|c|c|}
\hline $\begin{array}{l}\text { DRAWING LI } \\
\text { DEPARTEME } \\
\text { LRC NATUR }\end{array}$ & $\begin{array}{l}\text { IST } \\
\text { ENT OF E } \\
\text { AL GAS }\end{array}$ & $\begin{array}{l}\text { ENERGY } \\
\text { STORAGE }\end{array}$ & & Date & 1999-01-31 \\
\hline Drawing No. & Date & Name & Rev & Date & Remark \\
\hline EXGAZ -01 & 980831 & PROCESS DIAGRAM & A & 990121 & \\
\hline $\begin{array}{ll}\text { EXGAZ } & -02 \\
\end{array}$ & 980831 & PROCESS DIAGRAM LOADING WITH REDUCTION & A & 990121 & \\
\hline 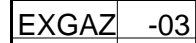 & 980831 & PROCESS DIAGRAM LOADING WITH COMPRESSION & A & 990121 & \\
\hline \begin{tabular}{ll|} 
EXGAZ & -04 \\
\end{tabular} & 980831 & PROCESS DIAGRAM WITHDRAWAL WITH REDUCTION & A & 990121 & \\
\hline EXGAZ & 980831 & PROCESS DIAGRAM WITHDRAWAL WITH COMPRESSION & A & 990121 & \\
\hline \begin{tabular}{ll|} 
EXGAZ & -06 \\
\end{tabular} & 980831 & PROCESS DIAGRAM CIRCULATION COOLING/HEATING & A & 990121 & \\
\hline \begin{tabular}{ll|} 
EXGAZ & -07 \\
\end{tabular} & 980902 & NEW ENGLAND LAY-OUT & - & & \\
\hline $\begin{array}{ll}\text { EXGAZ } & -08 \\
\end{array}$ & 980902 & PIPING IN STORAGE ROOM & - & & \\
\hline EXGAZ -12 & 990128 & STORAGE ROOM, SECTION SITE 2 & - & & \\
\hline 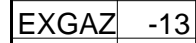 & 990128 & ROCK REINFORCEMENT & - & & \\
\hline EXGAZ -14 & 990128 & ACESS TUNNEL, SECTION STRAIGHT, CURVE & - & & \\
\hline EXGAZ -15 & & GENERAL LAYOUT & - & & \\
\hline $\begin{array}{ll}\text { EXGAZ } & -16 \\
\end{array}$ & & CAVERN AND TUNNELLING CONFIGURATION & - & & \\
\hline & & & & & \\
\hline & & & & & \\
\hline & & & & & \\
\hline & & & & & \\
\hline & & & & & \\
\hline
\end{tabular}




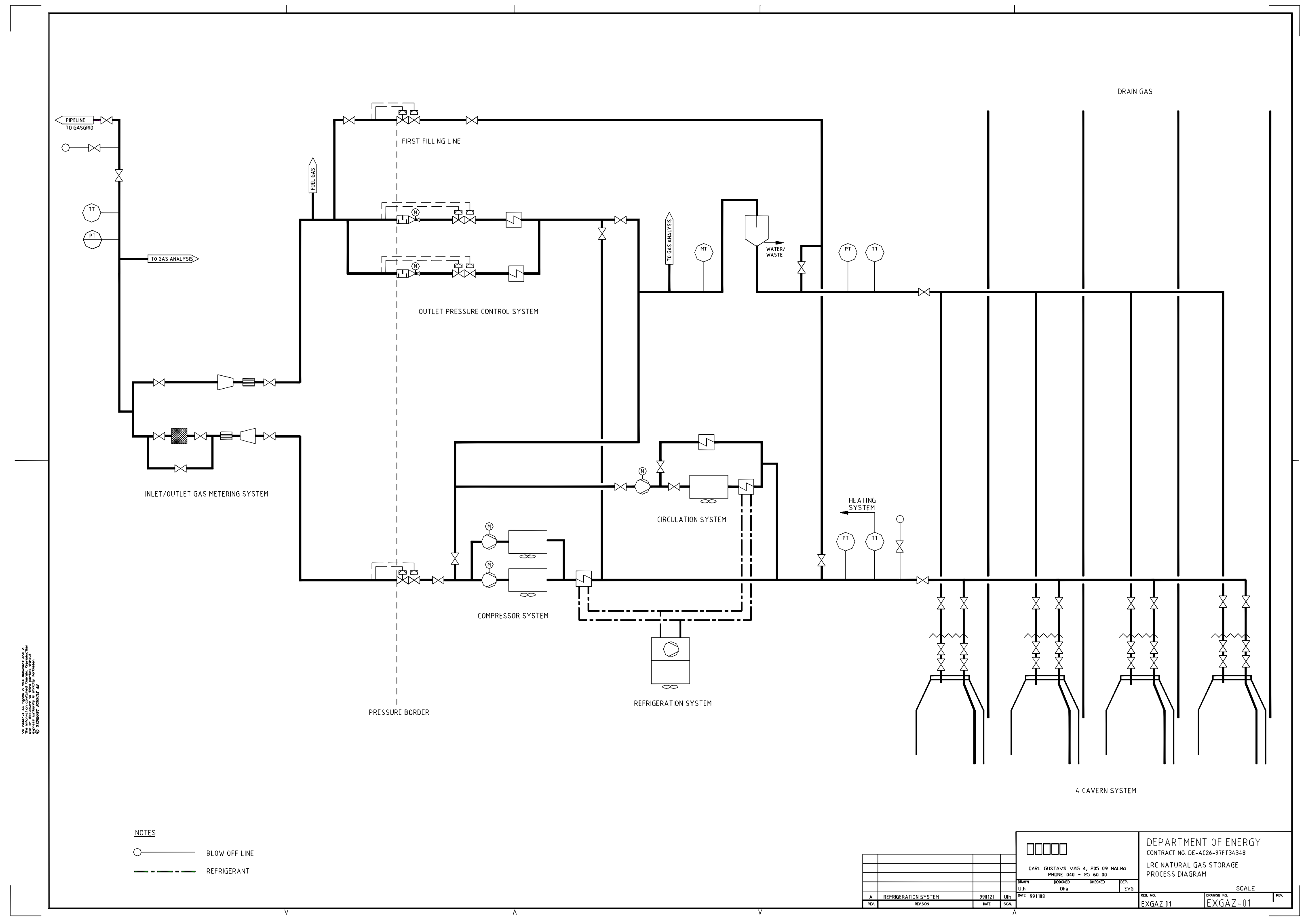




$$
\text { and }
$$




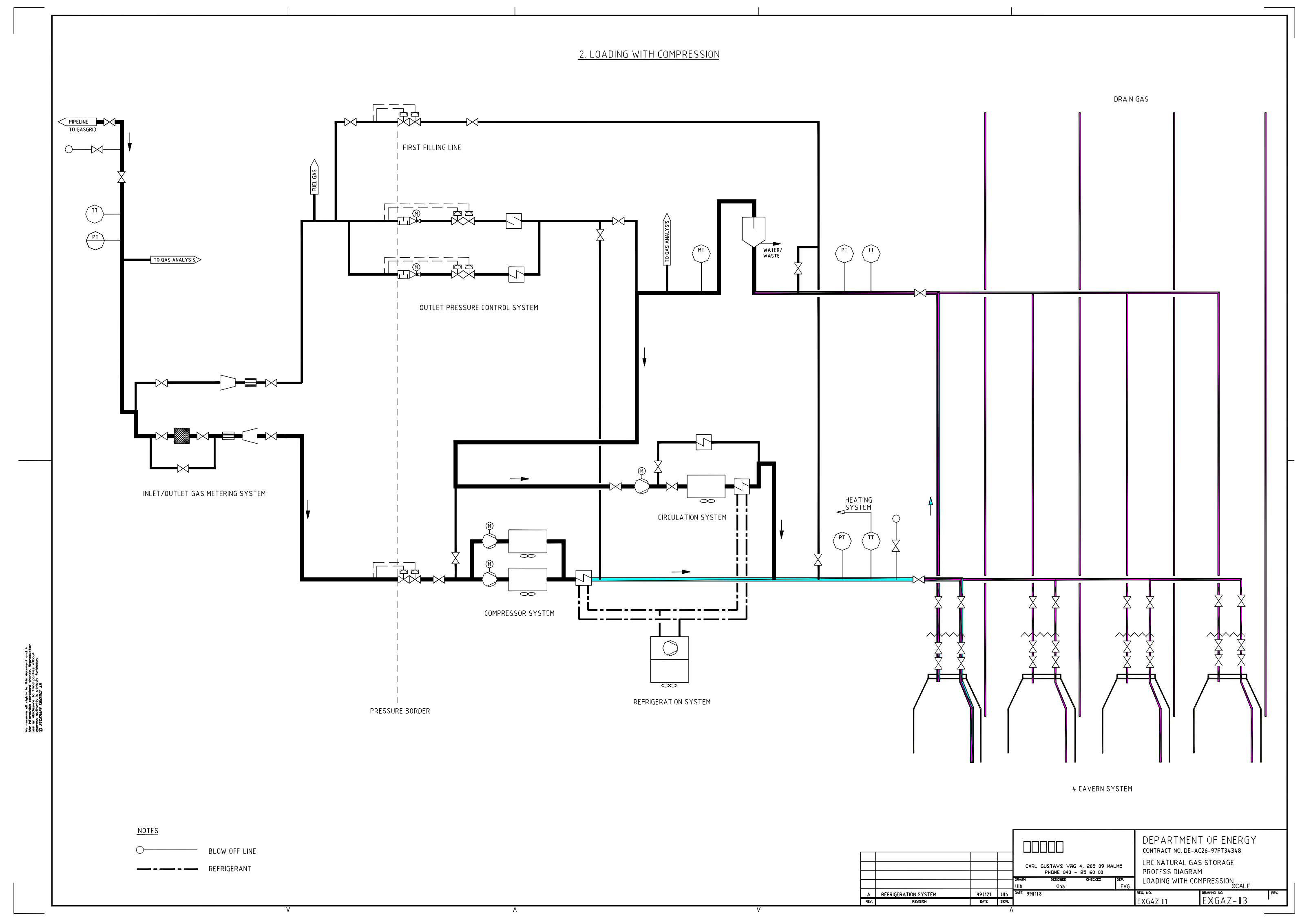




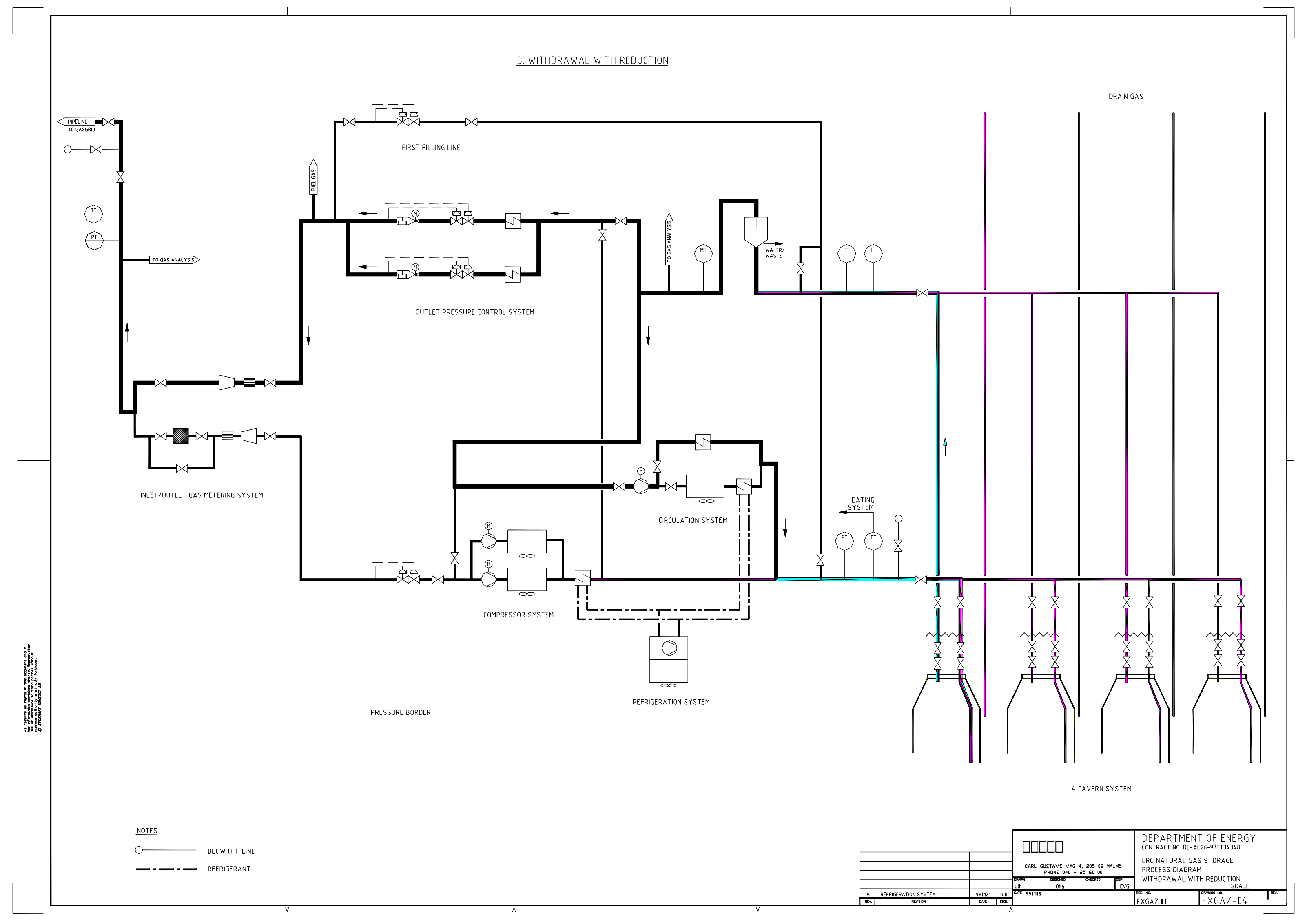




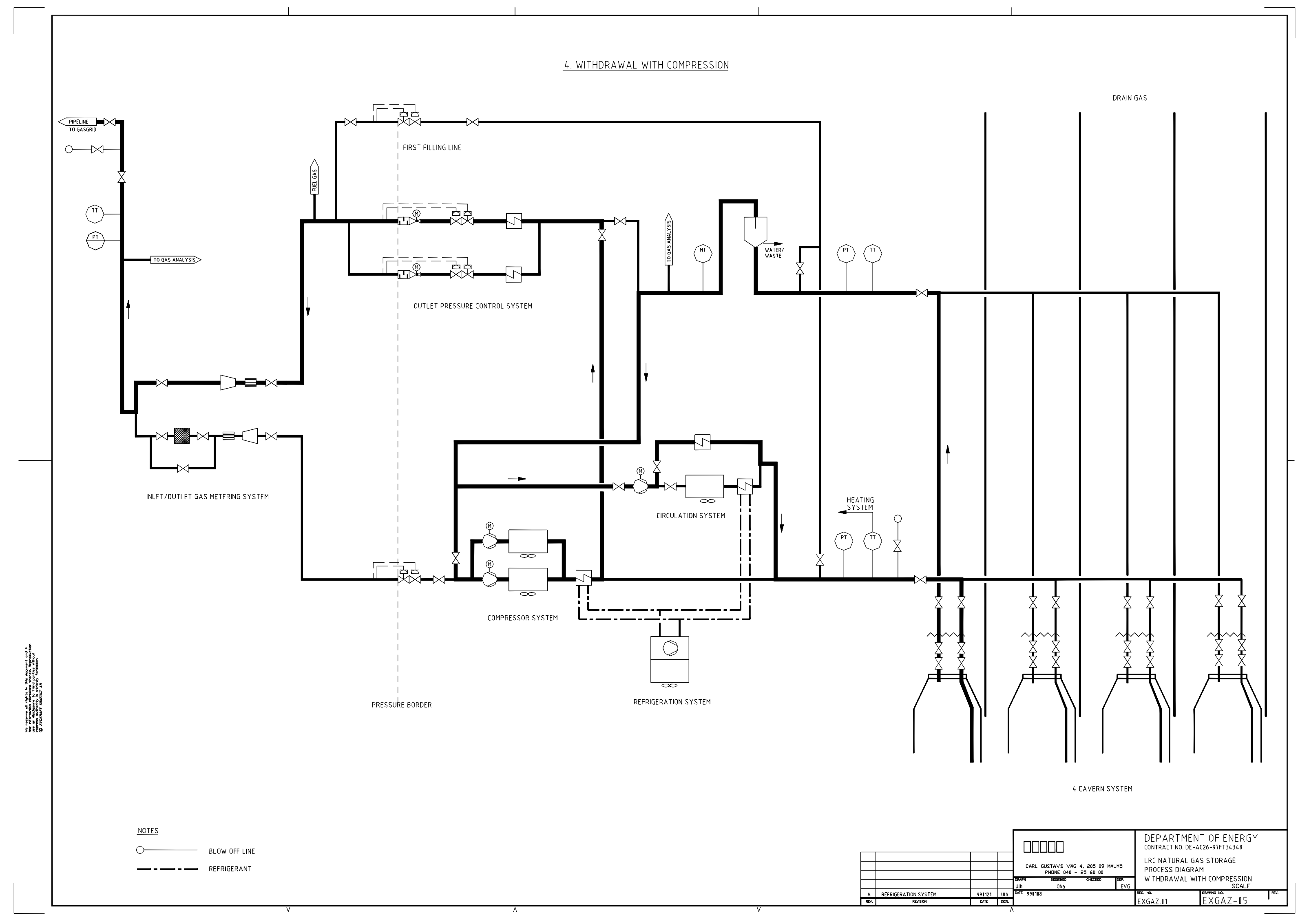




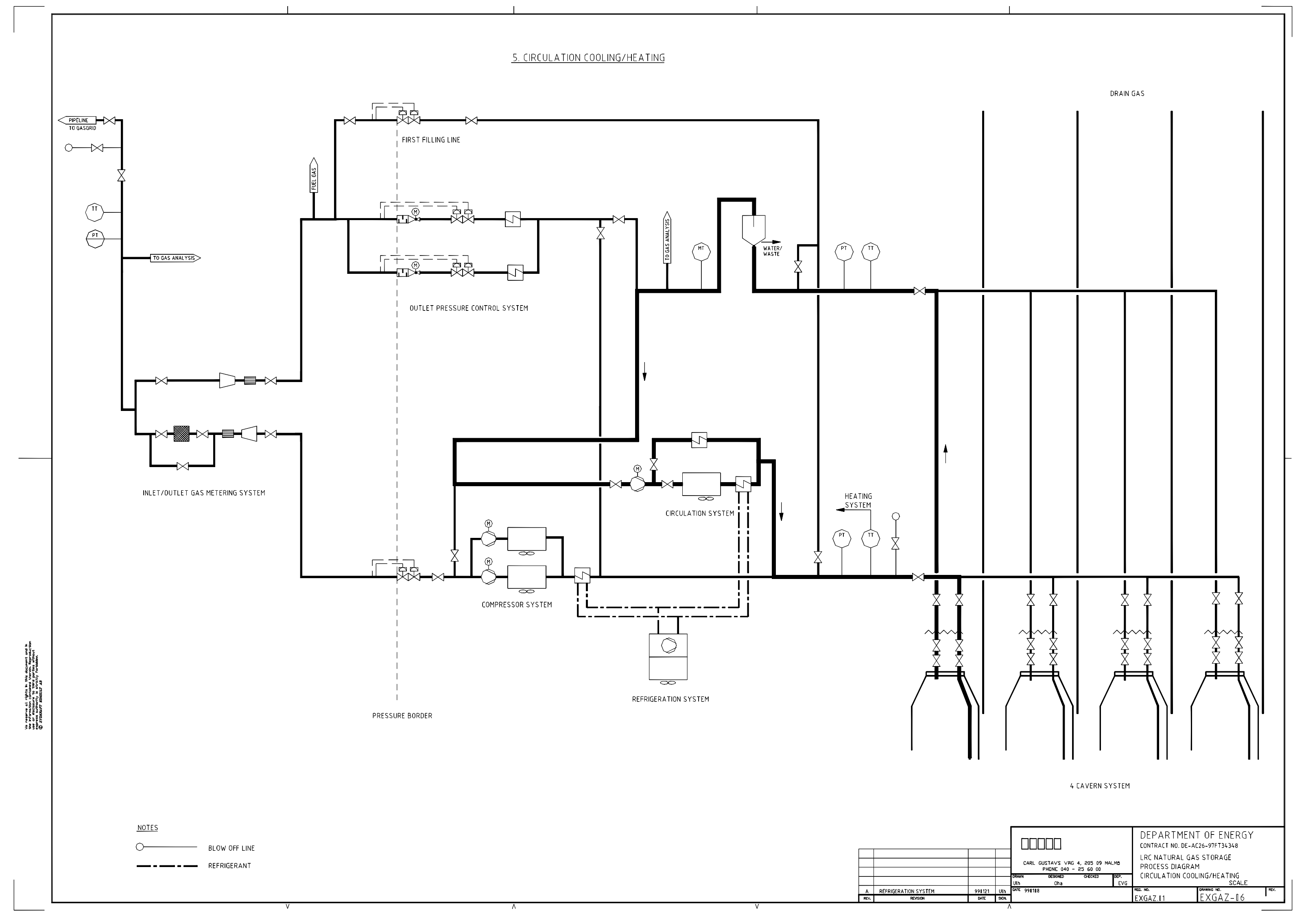




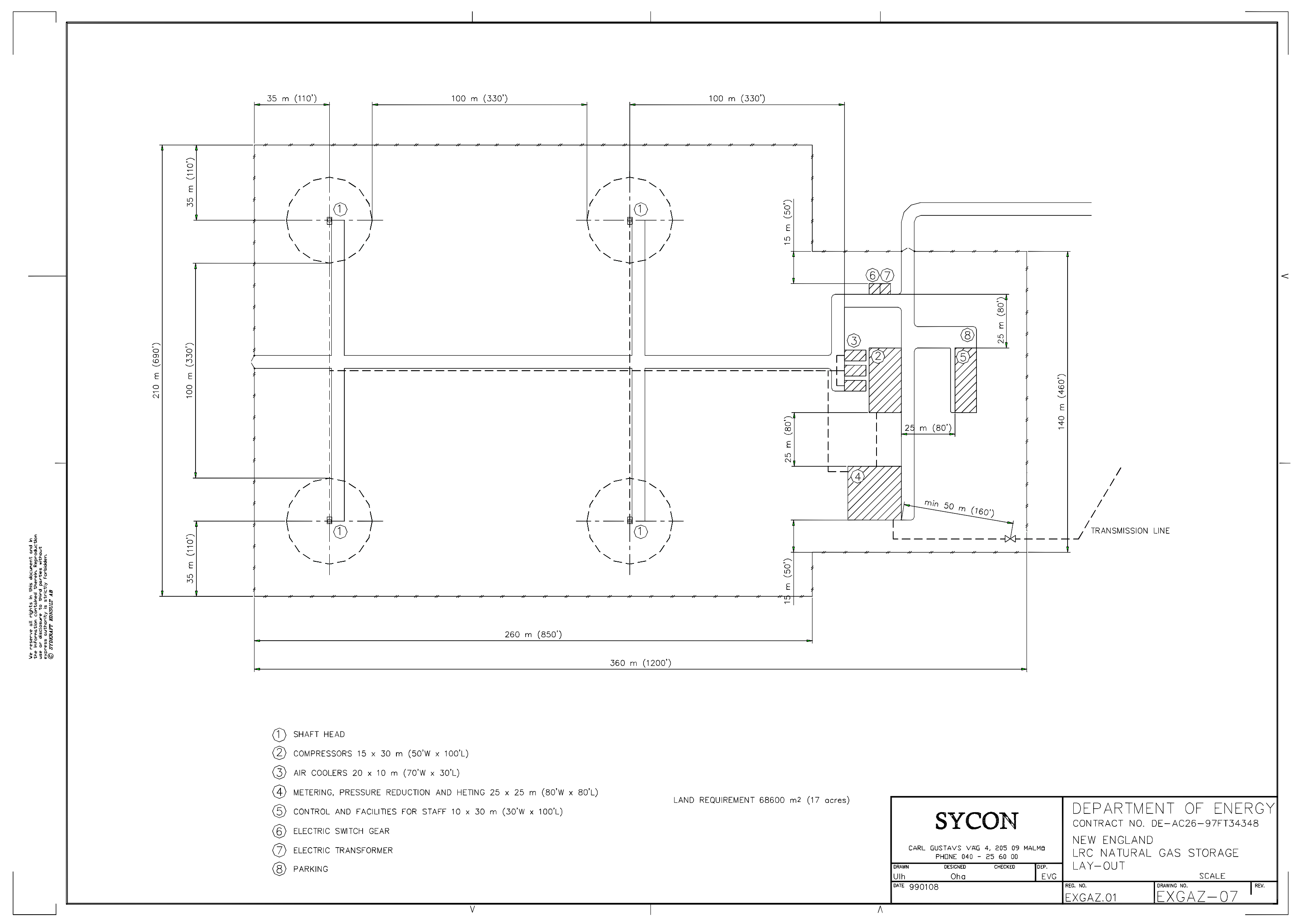




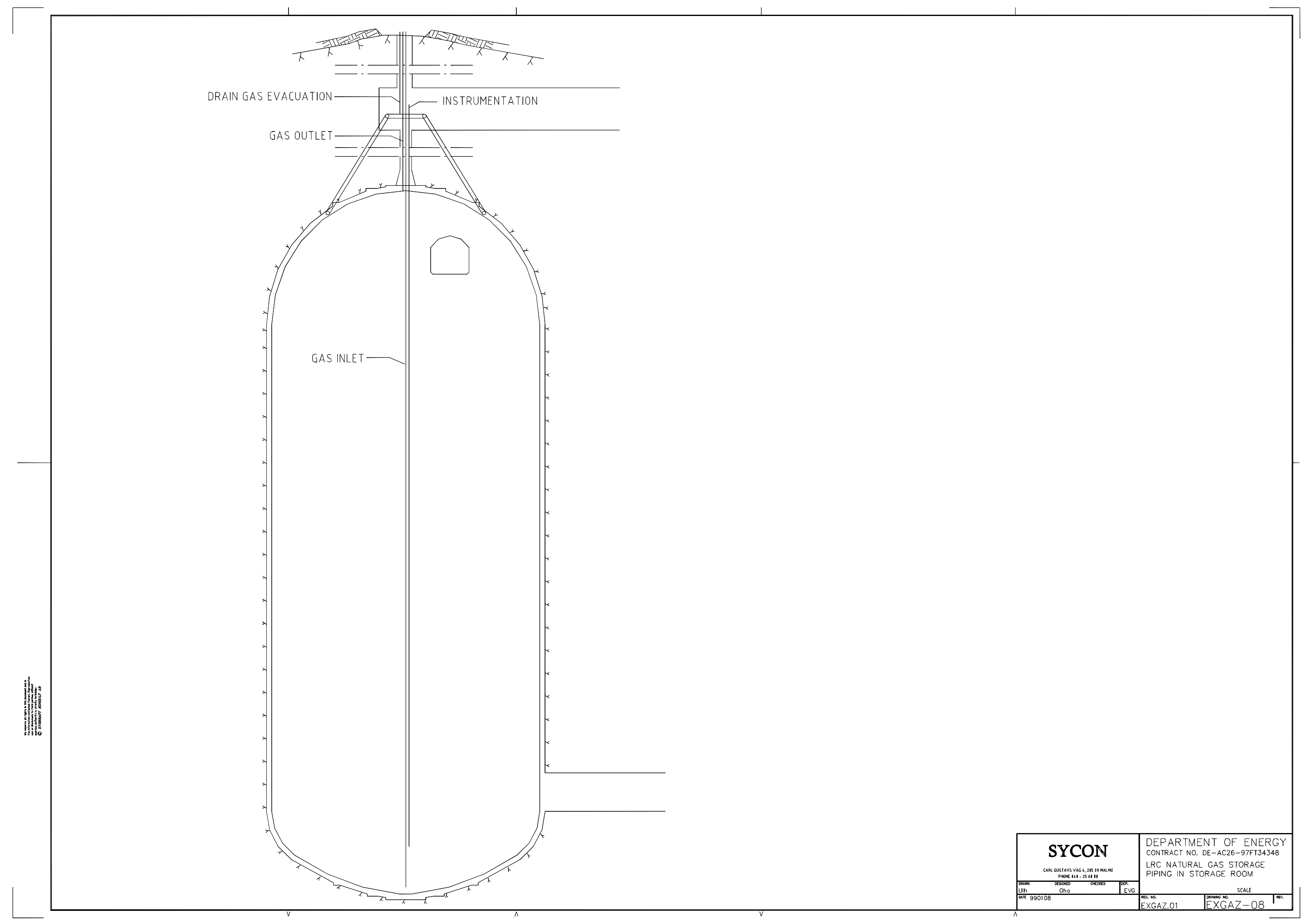




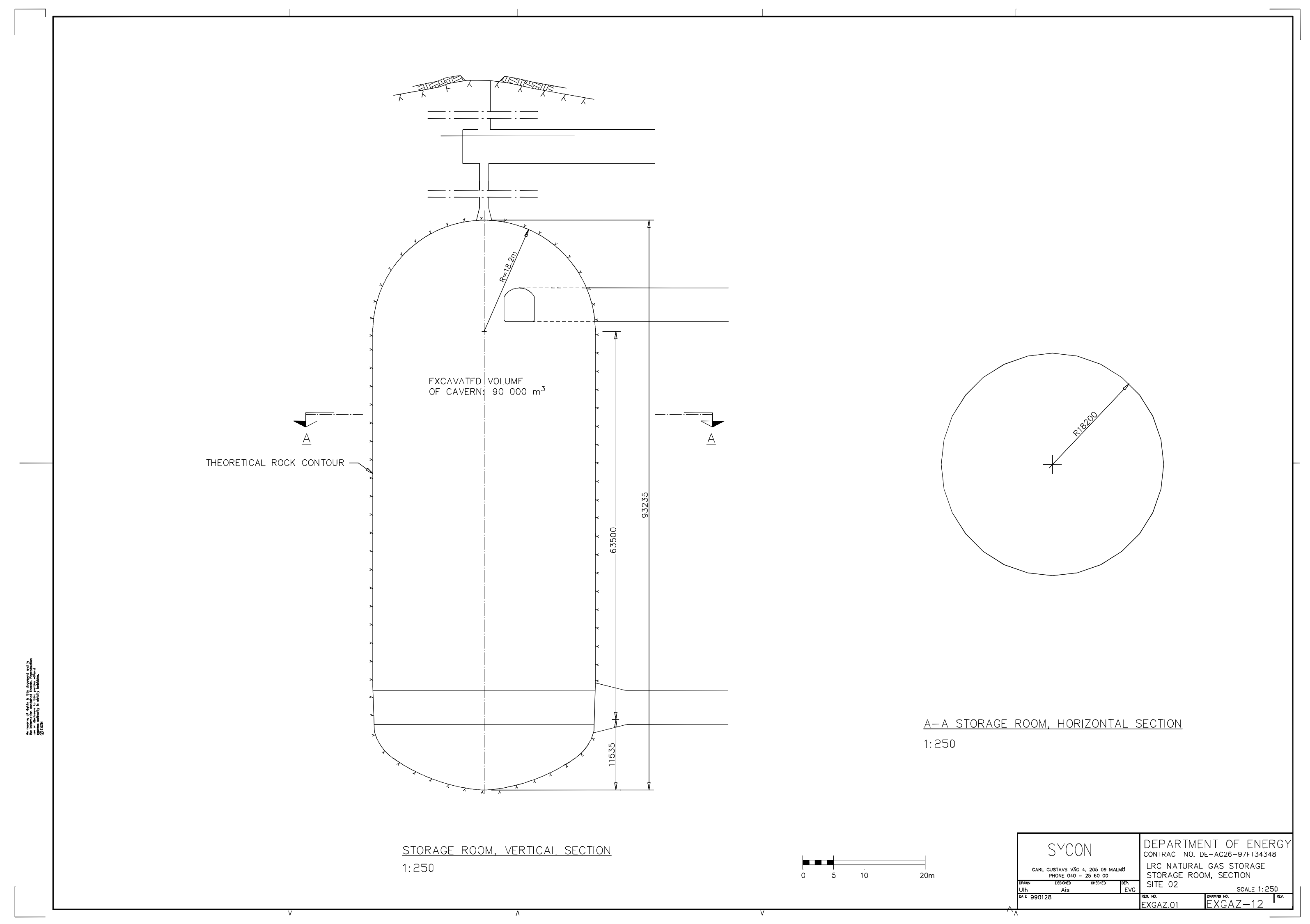




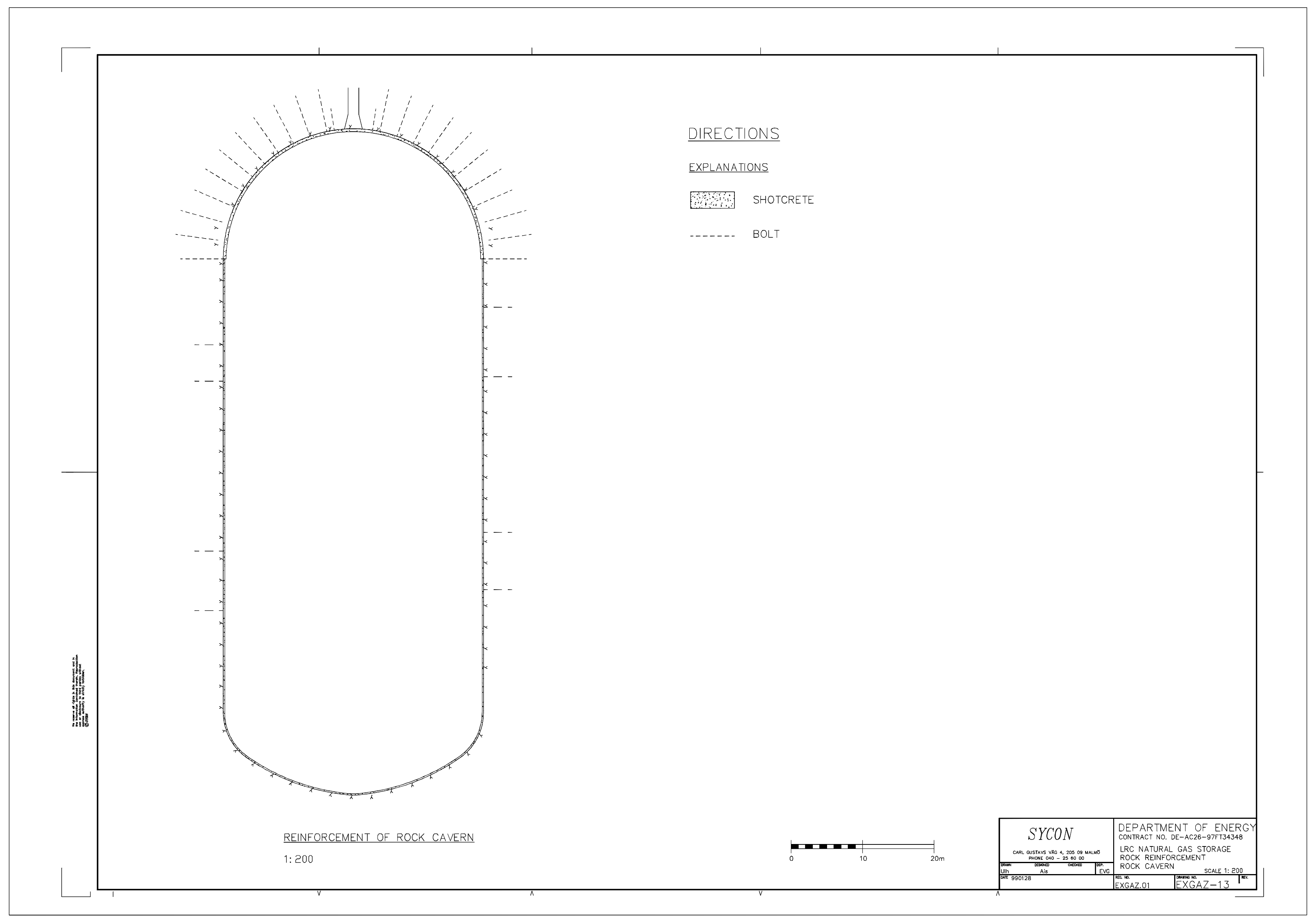




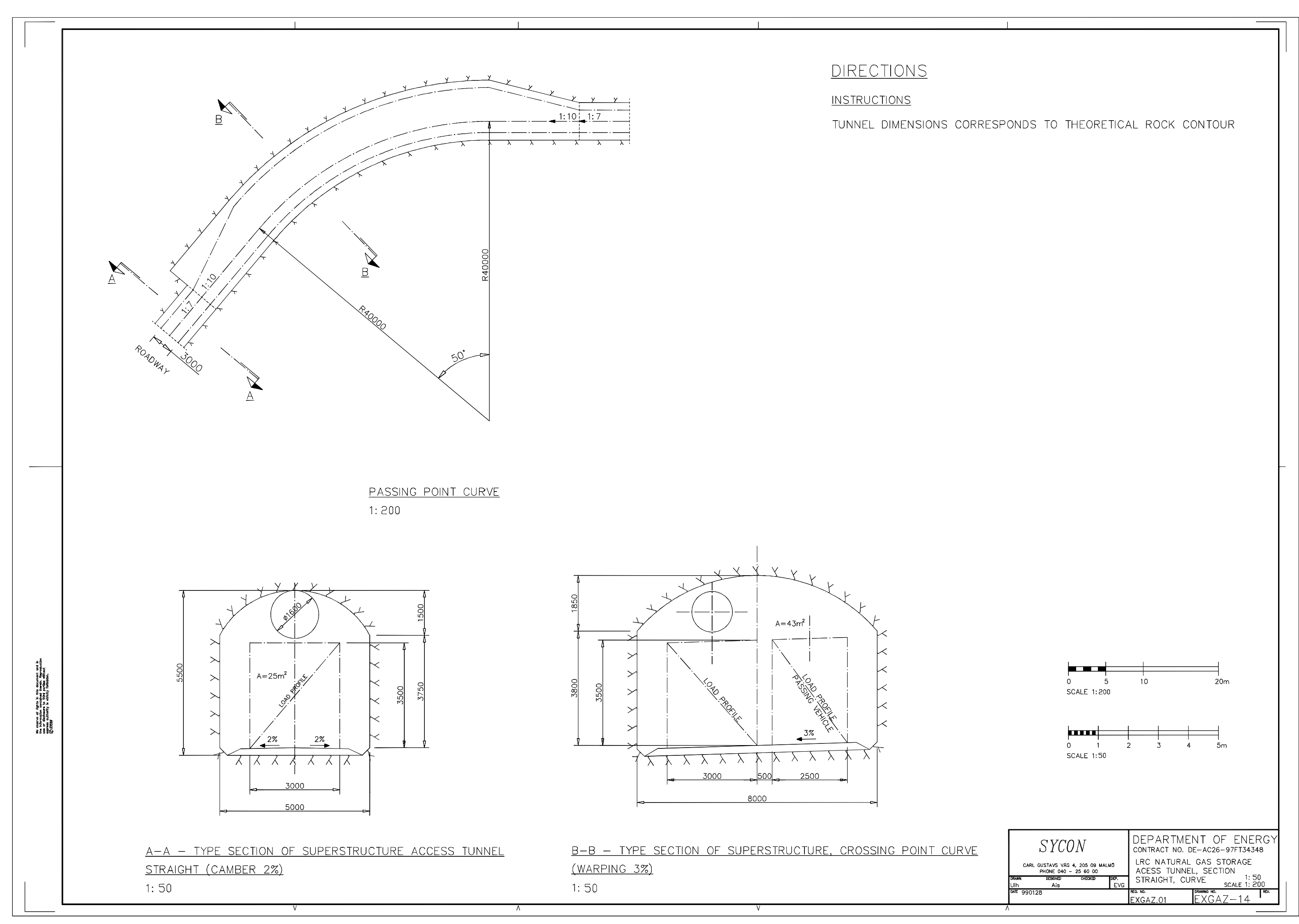




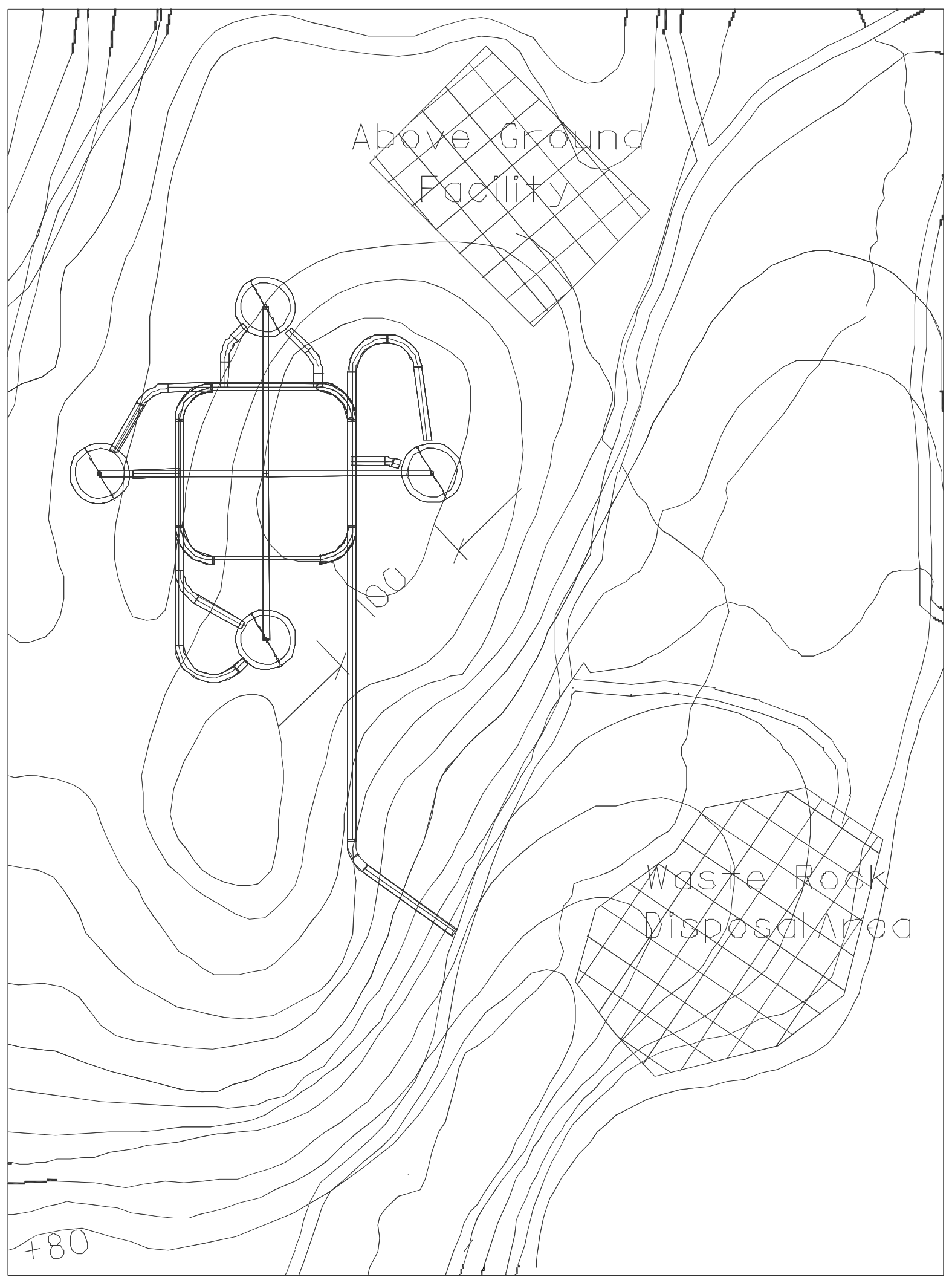

Drawing No. EXGAZ-15. General Layout. 


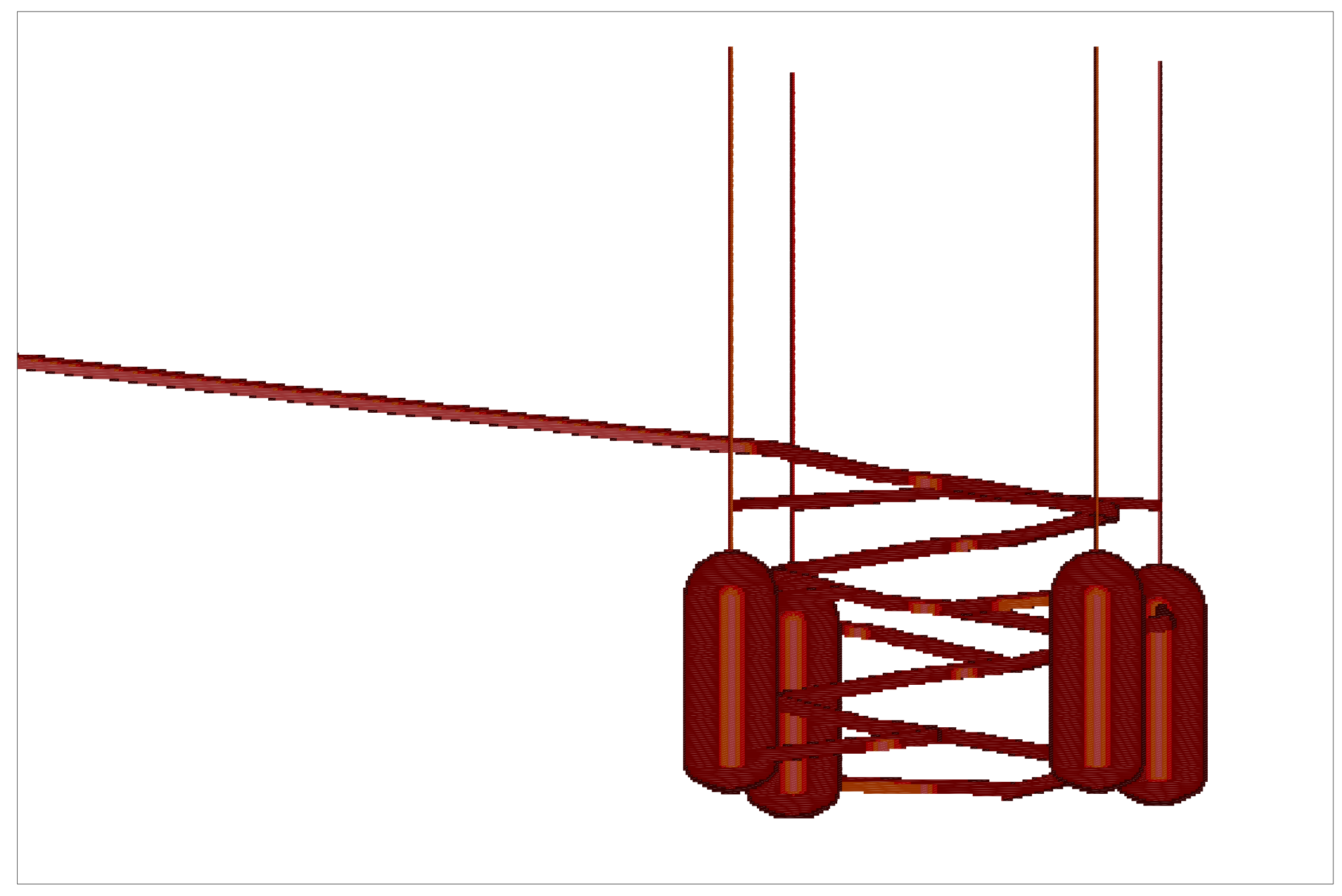

Drawing No. EXGAZ-16. Cavern and Tunneling Configuration. 


\section{APPENDIX D}

MANUAL FOR ECONOMIC MODEL

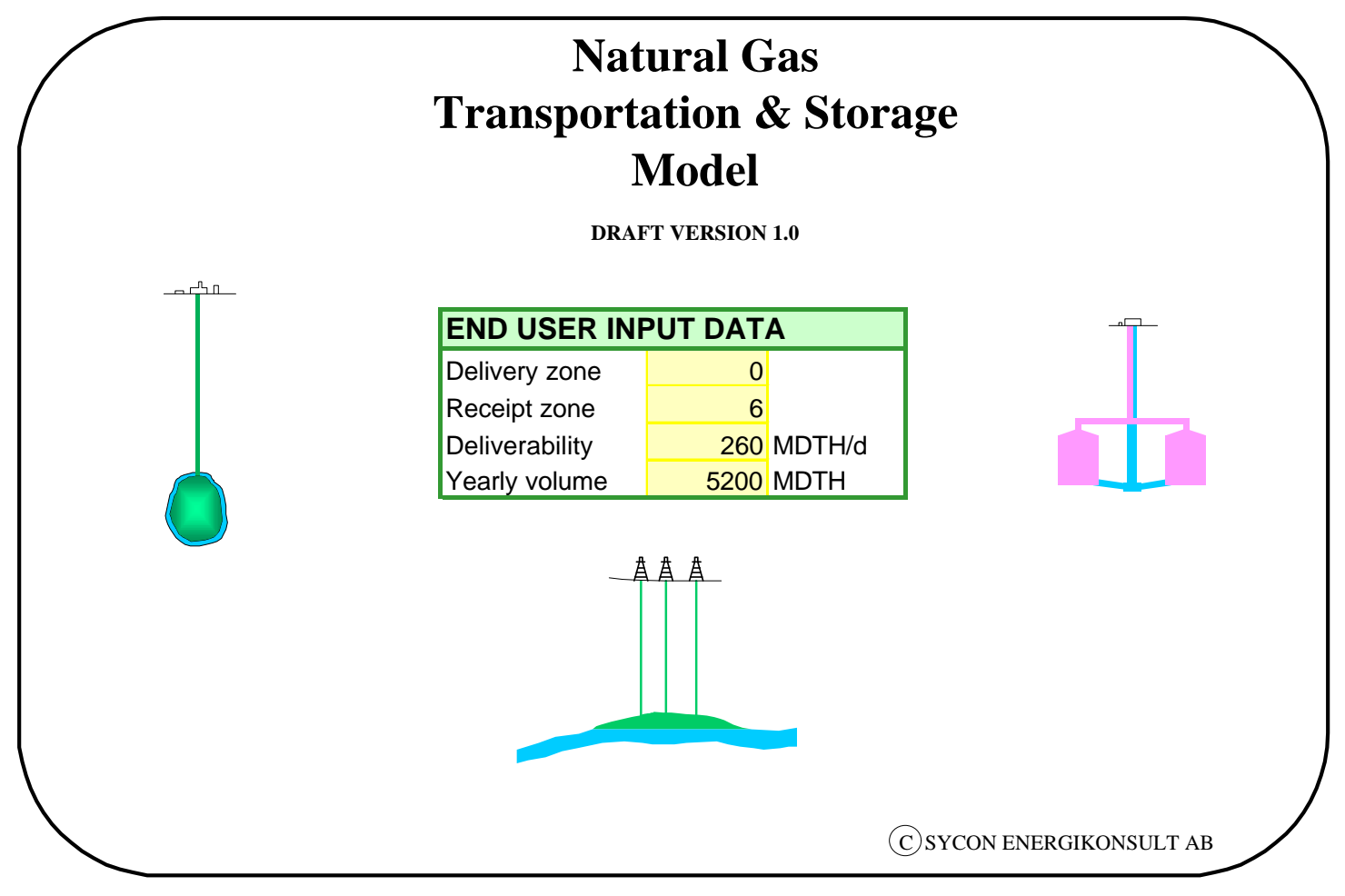

D-1 


\section{APPENDIX D \\ MANUAL FOR ECONOMIC MODEL}

\section{D.1 INTRODUCTION}

This economic model was developed by Sycon Energikonsult ${ }^{\odot}$, Sweden. It is developed in Microsoft Excel 97, SR-2.

The economic model can be used for two types of investigations:

1. Evaluation of investment and operating cost for an LRC storage facility.

2. Evaluation of a cost estimate for transportation of natural gas between different parts of the eastern United States gas grid.

A natural gas customer may wish to buy a certain yearly volume of gas and may have a certain need for deliverability. The gas is consumed in one zone and supplied in another. The gas has to be transported from the delivery zone to the receipt zone. As shown in Figure D-1, this can be done in two ways; either directly by pipeline or via storage. You can choose different storage types and they can be placed in different zones. With the model, alternatives can be compared and the most favorable alternative can be chosen.

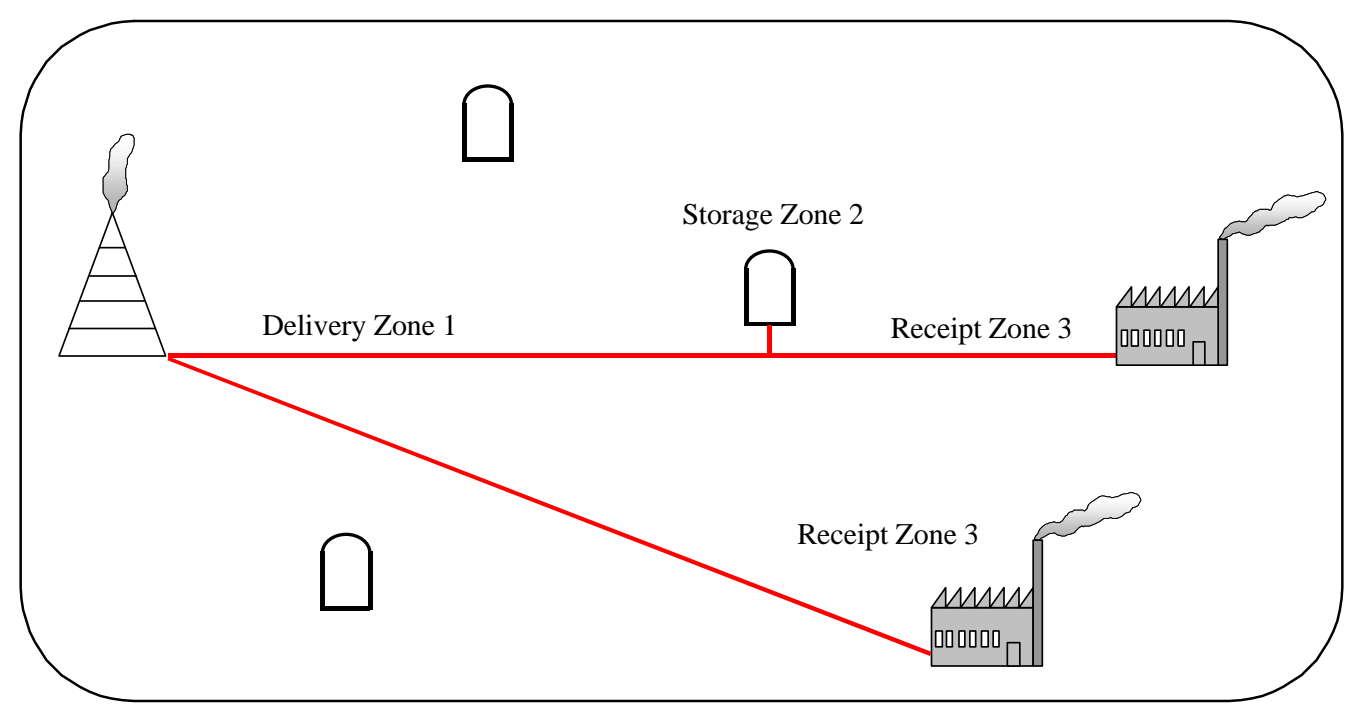

Figure D-1. Alternatives for Gas Transportation. 
The different types of storage that are handled by the model are:

- Salt cavern

- Depleted fields

- LRC

- LNG.

\section{D.2 BACKGROUND}

Storage costs for salt caverns and depleted fields are based on the study U.S. Underground Storage of Natural Gas in 1997: Existing and Proposed. The proposed storage projects in the study reflect the costs for building new storage projects.

Storage costs for LRC are based on the SECON model. The SECON model was developed by Sycon Energikonsult $\mathrm{AB}$ and was originally designed to calculate the costs for building LRC storage in Sweden. The costs in the model have been revised to match the United States' conditions.

LNG storage costs are based on the study titled Advanced Underground Gas Storage Concepts Refrigerated-Mined Cavern Storage, DOE Contract Number DE-AC26-97FT34349.

Transportation rates are those of the Tennessee Gas Pipeline Company.

\section{D.3 INSTRUCTIONS}

Cells used for input data in the spreadsheet model are yellow. In the model, the user can select the eight sheets noted below:

1. End User Input Data

2. Transportation Cost

3. Cost Comparison Graph

4. LRC Investment Cost

5. Storage Rate

6. i-Data

7. i-Model Transportation Rate

8. i-COS LRC. 
Some sheets in the model have a name that begins with "i;" for example, i-Data. These sheets give background information only.

\section{D.3.1 End User Input Data (Sheet 1)}

In this sheet, the user must insert the delivery zone and the receipt zone. The user will also have to insert the deliverability volume and the yearly volume to be transported, as illustrated in Figure D-2. As mentioned above, the cells with yellow cover are for inserting data.

\begin{tabular}{|l|r|}
\hline END USER INPUT DATA \\
\hline Delivery zone & 0 \\
Receipt zone & 6 \\
\hline Deliverability & $520 \mathrm{MDTH} / \mathrm{d}$ \\
\hline Yearly volume & $62400 \mathrm{MDTH}$ \\
\hline
\end{tabular}

Figure D- 2. End User Input Data.

\section{D.3.2 Transportation Cost (Sheet 2)}

In this sheet, the model calculates (1) the transportation cost directly by pipeline to the end user and (2) in the other alternative, via storage. The user must also give the size and performance for the LRC investment cost calculation on this sheet.

\section{D.3.2.1 Transportation Cost to End User (1.)}

The model calculates the cost for transportation of gas directly to the end user by pipeline. The model uses a firm transportation rate based on the chosen delivery and receipt zone. If the user wishes to use the calculated value from the model, the calculated value must be inserted in the cell for "Actual Transportation Rate." If another transportation rate is to be used, that value needs to be input in the cell for "Actual Transportation Rate" and the model will use that value instead. The user must always insert a value in the cell for "Actual Transportation Rate."

The model shows the yearly transportation cost. It also shows transportation cost per yearly gas volume and yearly transportation cost per deliverability, as shown in Figure D-3.

\section{D.3.2.2 Pipeline + Storage (2.)}

The next step in the modeled process is to calculate the cost for transportation of gas, including storage. 


\begin{tabular}{|l|}
\hline 1. PIPELINE TRANSPORTATION TO END USER \\
\hline TRANSPORTATION COST TO END USER \\
\begin{tabular}{|l|l|} 
Model transportation rate & 18.81 USD/DTH/d/month \\
Actual transportation rate & 18,81 USD/DTH/d/month \\
Yearly transportation cost & $\mathbf{1 1 7} 374$ 400 USD \\
Transportation cost per yearly gas volume & 2 USD/DTH \\
Yearly transportation cost per deliverability & 19 USD/DTH/d/month \\
\hline
\end{tabular}
\end{tabular}

Figure D-3. Transportation Cost to End User.

\section{Transportation Cost to Storage}

The model calculates the yearly transportation cost to the storage facility. The model uses a firm transportation rate based on the chosen delivery and storage zone. If the calculated value from the model is to be used, it should be input in the cell for "Actual Transportation Rate." If another transportation rate is to be used, it should be input in the cell for "Actual Transportation Rate" and the model will use that value instead. The user must always insert a value in the square for "Actual Transportation Rate" as shown in Figure D-4.

\begin{tabular}{|c|c|c|c|c|}
\hline \multicolumn{5}{|c|}{ TRANSPORTATION COST TO STORAGE } \\
\hline Storage injection rate & 50 & 50 & 50 & $13 \mathrm{MDTH} / \mathrm{d}$ \\
\hline Storage feeding time & 1248 & 1248 & 1248 & 4800 d \\
\hline Model transportation rate & 14,61 & 16,23 & 18,81 & 18,81 USD/DTH/d/month \\
\hline Actual transportation rate & 14,61 & 16,23 & 18,81 & 14,61 USD/DTH/d/month \\
\hline Yearly transportation cost & 8766000 & 9738000 & 11286000 & 2279160 USD \\
\hline
\end{tabular}

Figure D-4. Transportation Cost to Storage.

\section{Storage Cost}

The model calculates the yearly storage cost for the different types of storage based on calculated or inserted storage rates. The user must insert the storage zone for the different types of storage.

The model calculates the storage rates based on the investment and operating cost for salt caverns, depleted fields, and LRC. The investment cost for salt caverns is based on projects listed in the i-Data sheet. For LRC, the model calculates the investment cost. The storage rates are calculated based on the development cost in sheet i-Data (salt and depleted fields) or calculated (LRC) with the cost of service model. For LNG, a number of storage rates are included in the model. The model will pick the relevant rate, depending on the given storage zone.

If the user wishes to use the calculated value from the model, this rate should be input in the cell for "Actual Storage Rate." A numerical value must always be input for "Actual Storage 
Rate" except for LRC. For LRC, there is no actual storage rate, so the model will always use the calculated storage rate.

If the user wishes to use an actual storage rate, that rate must be input in the cell for "Actual Storage Rate" and the model will calculate with that value instead.

For LRC, various working gas volumes, deliverability, injection rate, and number of cycles can be input to obtain the best option for minimizing the transportation cost. The calculated storage rate is presented in the "Transportation Cost" sheet (see Figure D-5). The investment cost is detailed in the "LRC-Investment Cost" sheet (described in Section D.3.6).

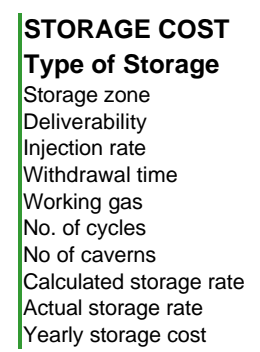

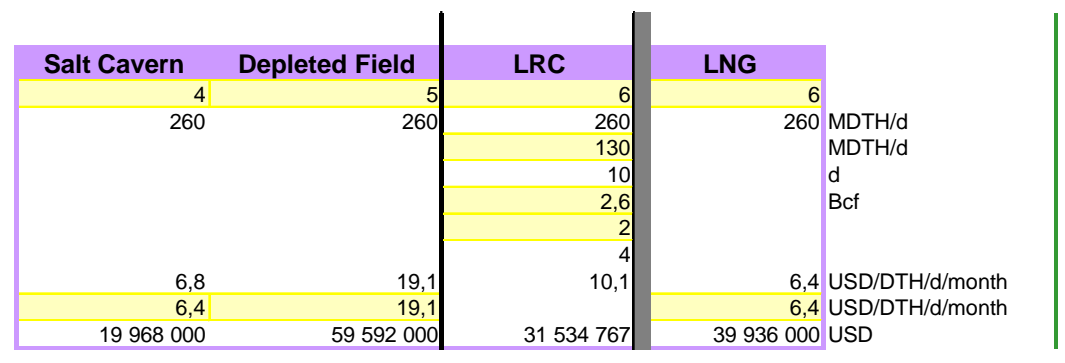

Figure D-5. Storage Cost.

\section{Transportation Cost to End User}

The model calculates the yearly cost for transportation of gas from the storage facility to the end user. The model uses a transportation rate based on the chosen storage zone and the chosen receipt zone. If the user wishes to use the calculated value from the model, this rate must be input in the cell for "Actual Transportation Rate." If the user wishes to calculate with another transportation rate, that rate must be input in the cell for "Actual Transportation Rate" and then the model will use that value instead.

If the user inputs a "Y" in the cell for "Customer Connected Directly to Storage," then the model will not account for any cost for transportation from storage to the end user.

The model shows the total yearly cost for the different alternatives with storage. It also shows the total cost per yearly gas volume and per deliverability.

Finally, the yearly cost difference between using pipeline transportation plus different storages and alternative pipeline transportation directly to the end user is provided as shown in Figure D-6. 


\begin{tabular}{|c|c|c|c|c|c|}
\hline \multicolumn{6}{|l|}{ TRANSPORTATION COST TO END USER } \\
\hline Customer connected directly to storage $(\mathrm{Y} / \mathrm{N})$ & $\mathrm{N}$ & $\mathrm{N}$ & $\mathrm{N}$ & $\mathrm{N}$ & \\
\hline Model transportation rate & 7,81 & 6,82 & 5,01 & 7,81 & 1 USD/DTH/d/month \\
\hline Actual transportation rate & 7,81 & 6,81 & 5 & 7,8 & 8 USD/DTH/d/month \\
\hline Yearly transportation cost & 48734400 & 42494400 & 31200000 & 48672000 & ] USD \\
\hline Total yearly cost & 97436400 & 171416400 & 118642987 & 500231160 & USD \\
\hline Total cost per yearly gas volume & 1,6 & 2,7 & 1,9 & & USD/DTH \\
\hline Total yearly cost per deliverability & 15,6 & 27,5 & 19,0 & 80,2 & 2 USD/DTH/d/month \\
\hline Yearly cost difference 2-1 & -19938000 & 54042000 & 1268587 & 382856760 & 0 USD \\
\hline
\end{tabular}

Figure D-6. Transportation Cost to End User.

\section{D.3.3 Cost Comparison Graph}

In the cost comparison graph, the transportation cost for the different alternatives and the allocation of transportation costs are illustrated in Figure D-7.

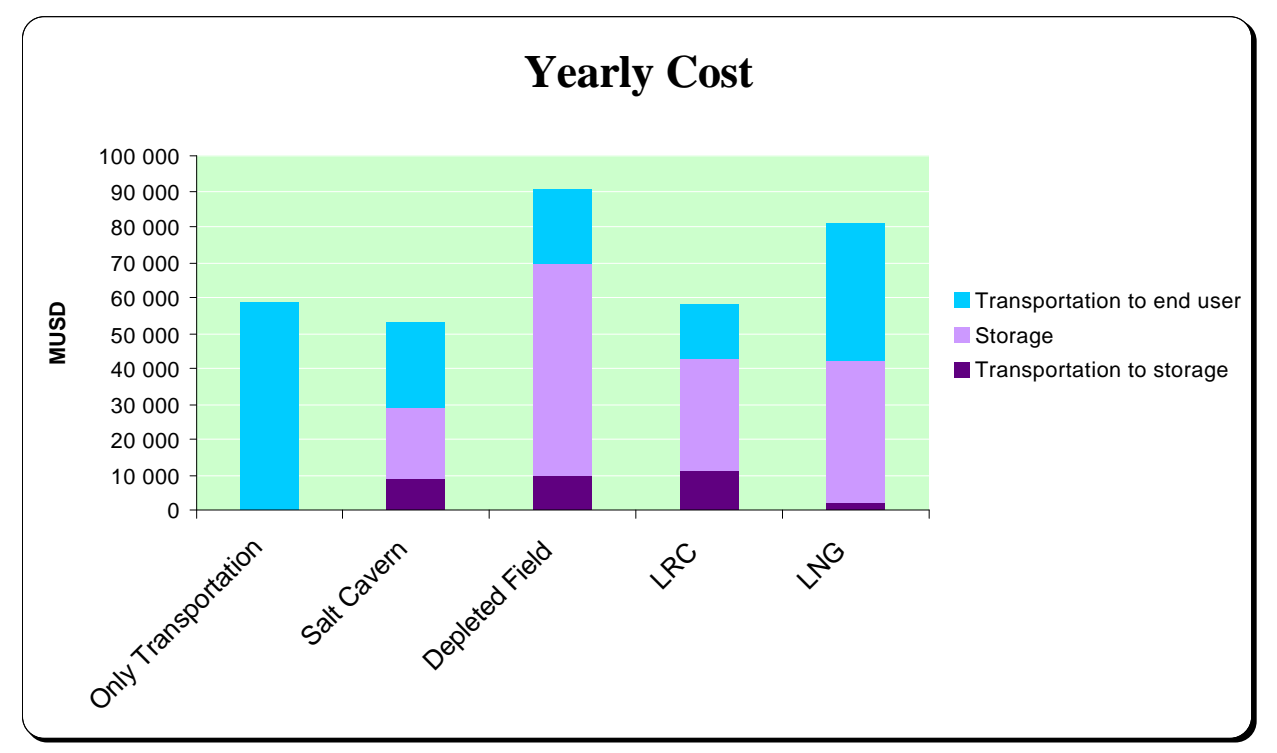

Figure D-7. Cost Comparison Graph.

\section{D.3.4 Storage Rate}

As shown in Figure D-8, the actual storage rate and the calculated storage rate for the different storage types in the selected storage zone are illustrated by the model.

\section{D.3.5 LRC Investment Cost}

The model shows the investment costs for LRC, based on the working gas volume, deliverability, injection rate, and number of cycles that are input to the model, as shown in Figure D-9. 


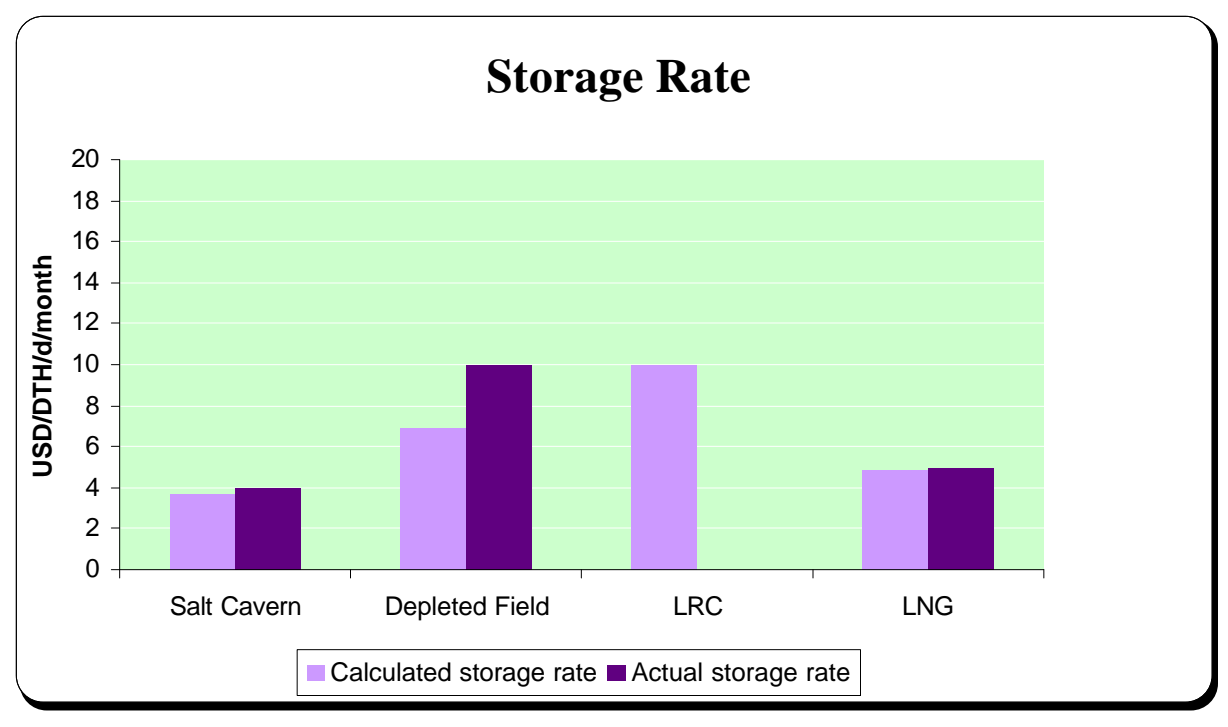

Figure D-8. Storage Rate.

\begin{tabular}{|c|c|}
\hline Deliverability & $6 \mathrm{MDTH} / \mathrm{d}$ \\
\hline Working gas & $5,2 \mathrm{Bcf}$ \\
\hline Injection rate & $260 \mathrm{MDTH} / \mathrm{d}$ \\
\hline No. of cycles & 12 \\
\hline Pre-Construction & 7000 MUSD \\
\hline Below Ground Cost & 239480 MUSD \\
\hline Above Ground & 62000 MUSD \\
\hline Base Gas & 2500 MUSD \\
\hline Subtotal & 310980 MUSD \\
\hline AFUDC & 35189 MUSD \\
\hline Total & 346169 MUSD \\
\hline
\end{tabular}

Figure D-9. LRC Investment Cost. 